\title{
Fruits, seeds and flowers from the Bovay and Bolden clay pits (early Eocene Tallahatta Formation, Claiborne Group), northern Mississippi, USA
}

\author{
Jane Blanchard, Hongshan Wang, and David L. Dilcher
}

\begin{abstract}
This report is the second of a series of comprehensive reviews of the reproductive material from localities of the Eocene Claiborne Group of the southeastern United States. We examine fossil plant reproductive material from two localities, the Bovay and Bolden clay pits, in northern Mississippi, USA. The investigation of 193 specimens has resulted in the recognition of 52 taxa/morphotypes. Based upon comparisons of gross morphology of these specimens with available extant plant material and the literature, we are able to relate 17 taxa/morphotypes to the following 11 extant families: Annonaceae (1), Araliaceae (1), Caprifoliaceae (1), Eucommiaceae (1), Fabaceae (6), Fagaceae (2), Icacinaceae (1), Sapindaceae (1), Salicaceae (1), Rhamnaceae (1), and Theaceae (1). In addition, 35 morphotypes are not assigned to any family due to the limited number of diagnostic characters. Of the 52 taxa/morphotypes recognized, 38 $(73.1 \%)$ are unique to the Bovay locality and nine $(17.3 \%)$ are unique to Bolden. Only five $(9.6 \%)$ taxa/morphotypes are shared by the two localities. Of the 62 taxa/morphotypes recognized from the Warman clay pit, Tennessee, only eight taxa/morphotypes are shared with the Bovay and/or Bolden localities, Mississippi. This study has expanded our knowledge of the Eocene plant diversity of the southeastern United States and has shown that there is a remarkable lack of species overlap among the three localities examined to date.
\end{abstract}

Jane Blanchard. Florida Museum of Natural History, University of Florida, Gainesville, Florida 32611, USA Ojjhblanchard@aol.com

Hongshan Wang. Florida Museum of Natural History, University of Florida, Gainesville, Florida 32611, USA hwang@flmnh.ufl.edu (corresponding author)

David L. Dilcher. Departments of Biology and Geology, Indiana University, Bloomington, Indiana 47405, USA dilcher@indiana.edu

KEY WORDS: New species; reproductive material; Tallahatta Formation; early Eocene; Mississippi 


\section{INTRODUCTION}

Cenozoic fossil plants from Mississippi have been reported since the late 1800s. Publications from the late 1800 s and early 1900 s primarily focused on leaf material from various localities of the Claiborne Group (Lesquereux, 1869; Berry, 1914a, 1914b, 1916a, 1916b, 1922, 1924, 1926, $1928,1930,1941)$. More recent works mainly focused on a specific taxonomic group of fossil plants (Herendeen et al., 1992; Call et al., 1993; Call and Dilcher, 1997; Manchester, 1999; Manchester et al., 2009; Manchester and O'Leary, 2010; Stull et al., 2011).

Johnston (1993) and Johnston and Borkent (1998) reported a fauna, which predominately consisted of fossil insects and spiders, from the same plant-bearing horizon of the Bolden locality, northwestern Benton County, Mississippi (Figure 1). Insects reported from this locality include beetles, ants, termites, phantom midges, dragonflies, damselflies, caddisfly larval cases, and larvae. Compressions and impressions of fossil leaves, fruits, seeds, and flowers were also discussed by Johnston (1993), but without description and formal taxonomic treatments. Beetle elytra (hardened forewings), spiders, ants, and caddisfly larval cases are also observed in the Bovay clay pit, which is about $15 \mathrm{~km}$ southwest of the Bolden locality, in Marshall County, Mississippi (field observation; Figure 1).

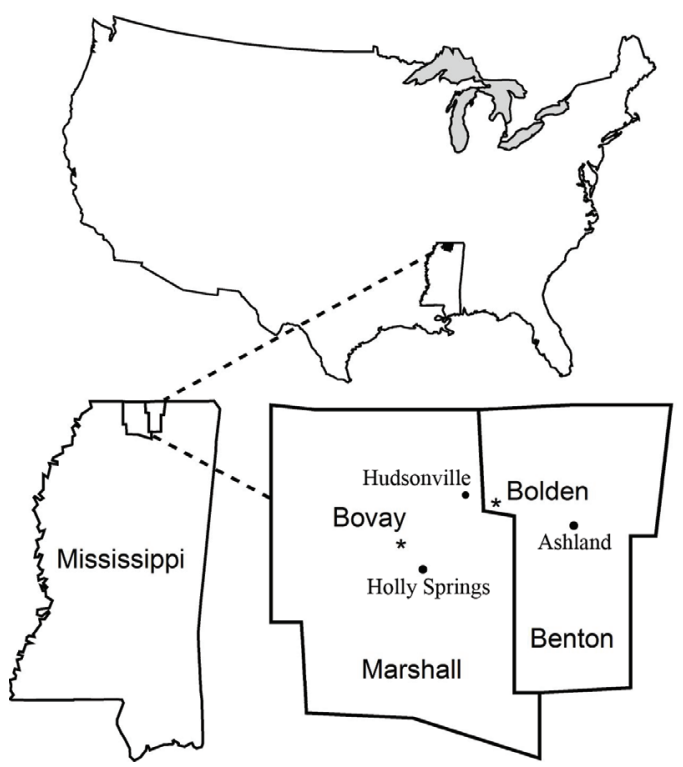

FIGURE 1. Locations of the Bovay clay pit (UF15737) in Marshall County, and Bolden clay pit (UF15738) in Benton County, northern Mississippi, USA.
This report is the first to comprehensively review all available reproductive material collected from two localities of the early Eocene Tallahatta Formation (Claiborne Group) from Mississippi and now stored at the Paleobotany Collection at the Florida Museum of Natural History, Gainesville, Florida. This paper is the second in a series of reviews of plant reproductive material from the Claiborne Group localities of the southeastern United States (Wang et al., 2013).

\section{MATERIAL AND METHODS}

Fossils reported in this paper were collected from the Bovay clay pit (UF15737; $34^{\circ} 47.76^{\prime} \mathrm{N}$, $\left.89^{\circ} 28.47^{\prime} \mathrm{W}\right)$, Marshall County, and the Bolden clay pit (UF15738; $34^{\circ} 51.491^{\prime} \mathrm{N}, 89^{\circ} 20.145^{\prime} \mathrm{W}$ ), Benton County, northern Mississippi, USA (Figure 1). Both clay pits are owned by the U.S. Brick Holly Springs Plant (700 Highway 7 N, Holly Springs, Mississippi 38635-1347; Tel. 662-252-2551). The Bovay pit (Figure 2.1) is on the north side of Highway $178,1.1 \mathrm{~km}$ east of the off-ramp from Highway

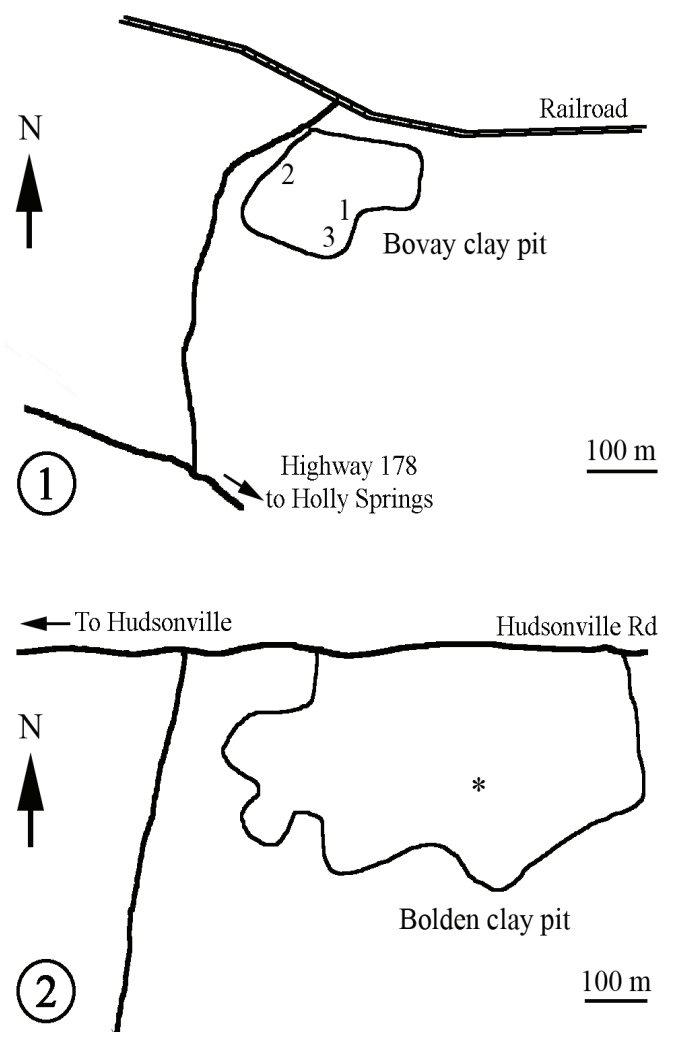

FIGURE 2. Sketch map showing collection sites in the Bovay clay pit and the Bolden clay pit, northern Mississippi: 1) Bovay clay pit. Numbers indicate collecting sites within the clay pit; 2) Bolden clay pit. * indicates the place where the section is measured in Johnston (1993, p. 73, text-figure 2). 
78 on the west side of Holly Springs, Mississippi. The Bovay pit (Figure 2.2) is not being actively mined. The Bolden pit is on the south side of Hudsonville Road, about $6.4 \mathrm{~km}$ east of Highway 7 and is actively mined. Specimens are preserved as either compressions or impressions. Most specimens were collected during field seasons between 1983 and 1993.

Specimens from both localities occur within the upper portion of the Tallahatta Formation of the Claiborne Group (Johnston, 1993; Dockery, 1996; Figure 3). We treat the specimens from the Bovay and Bolden localities in one paper because: (1) stratigraphically, the plant fossil-bearing horizons at these two localities are from the same formation, and (2) geographically, these two localities are only about $15 \mathrm{~km}$ apart.

The majority of the specimens from Bovay were collected from three sites within the clay pit (Figure 2.1). Among these, sites 1 and 2 are the most intensively sampled. The plant-bearing, tan clay layer at site 1 is about $3 \mathrm{~m}$ above the bottom of the clay pit. The plant-bearing, tan clay layer at site 2 is near the top of the section. Site 3 is about 1.5 $\mathrm{m}$ higher than site 1 . Unfortunately, field notes do not indicate at which site a particular specimen was collected and the whole section was never measured.

Specimens from the Bolden clay pit were collected from a thin siltstone layer $(0.17 \mathrm{~m})$ about 1.1 $\mathrm{m}$ above the bottom of the clay pit (Johnston, 1993, text-figure 2) (Figure 2.2). The entire section is $17.5 \mathrm{~m}$ thick and includes the Tallahatta and Kosciusko formations. At this locality, the Tallahatta Formation contains three layers: (1) white to brown to pink, fine- to medium-grained sand layer about $1.1 \mathrm{~m}$ thick at the bottom; (2) reddish brown siltstone layer $(0.17 \mathrm{~m})$ in the middle; and (3) pale yellowish brown to pinkish gray, slightly silty clay layer $(7.4 \mathrm{~m})$ at the top.

Specimens that have been published previously and have sufficient characters to assess their modern affinities are assigned to extant families. The relationships with modern families of some specimens, for example, cf. Populus sp., that lack diagnostic characters, are inferred from their cooccurrence with other organs (e.g., leaves) at the same locality or at localities of equivalent age (Manchester et al., 2014). These families are arranged according to the Angiosperm Phylogeny Group III (APG III, 2009). The following databases and websites were consulted: The Families of Flowering Plants (Watson and Dallwitz, 1992 onwards), Legume (Fabaceae) Fruits and Seeds

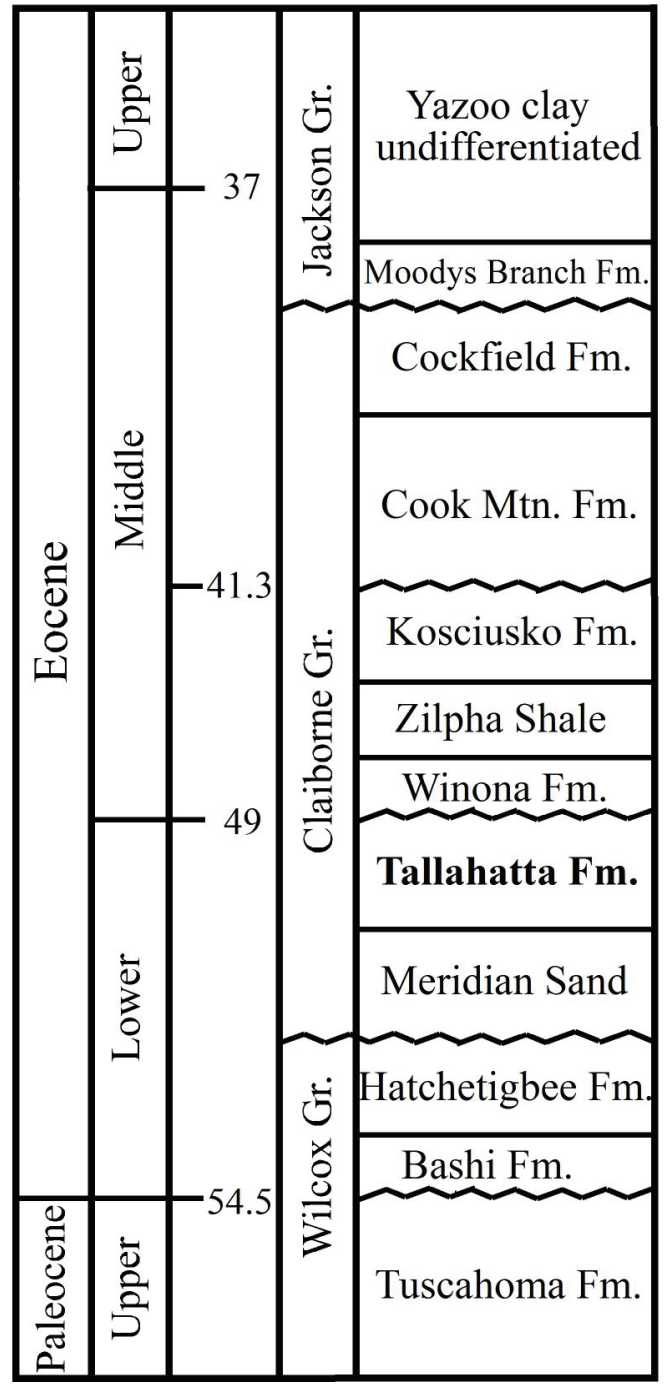

FIGURE 3. Simplified stratigraphic column of the middle Eocene Claiborne Group in northern Mississippi (after Dockery, 1996). Specimens examined in this paper were collected from the Tallahatta Formation at Bovay and Bolden localities, Mississippi. Specimens from other localities used for comparison to the Tallahatta Formation, including the Warman clay pit, were collected from the Cockfield Formation in western Tennessee and southwest Kentucky.

(Kirkbride et al., 2015), Family Guide for Fruits and Seeds (Kirkbride et al., 2006), The International Plant Names Index (IPNI, 2016), and Angiosperm Phylogeny Website (Stevens, 2001 onwards). The specimens, whose modern affinities are uncertain, or cannot be related to the familial or higher rank, are classified into morphotypes with informal names. Their arrangement in the text is by their organ types in the following order: inflorescences (flowers), infructescences, fruits, seeds, and other undermined. We add "Claiborne" to a morphotype 
name in order to refer to its occurrence in the Claiborne Group. For example, we use "Claiborne Floral Type" to name flowers and their disarticulated parts. For morphotypes whose modern affinities are relatively certain, we add a familial or ordinal name to indicate their possible placement within an extant family or order. For example, we use "Claiborne Fagaceae Fruit Type 1" to indicate a fruit type closely related to the modern family Fagaceae. Regardless of their occurrences at different localities within the Claiborne Group, we number all morphotypes of the same organ consecutively, using Arabic numerals. For consistency, we also renamed the morphotypes from the Warman clay pit, Tennessee (Wang et al., 2013). Table 1 lists all taxa/morphotypes reported from the Bovay, Bolden, and Warman localities. Following the description of each taxon/morphotype, the total number of specimens examined and catalog numbers for the illustrated specimens are listed.

\section{SYSTEMATIC PALAEONTOLOGY}

Order MAGNOLIALES Bromhead, 1838

Family ANNONACEAE de Jussieu, 1789

Genus ANONASPERMUM Ball, 1931

Type species. Anonaspermum robertsi (Berry) Wang, Blanchard, and Dilcher, 2013, by original designation.

Anonaspermum robertsi (Berry)

Wang, Blanchard, and Dilcher, 2013

(Figure 4)

* 1930 "Anona” robertsi Berry, p. 70-71, pl. 41, figs. 14-18.

v. 2013 Anonaspermum robertsi (Berry) Wang, Blanchard, and Dilcher, p. 6, figs. 4.1-4.3, 4.5-4.8.
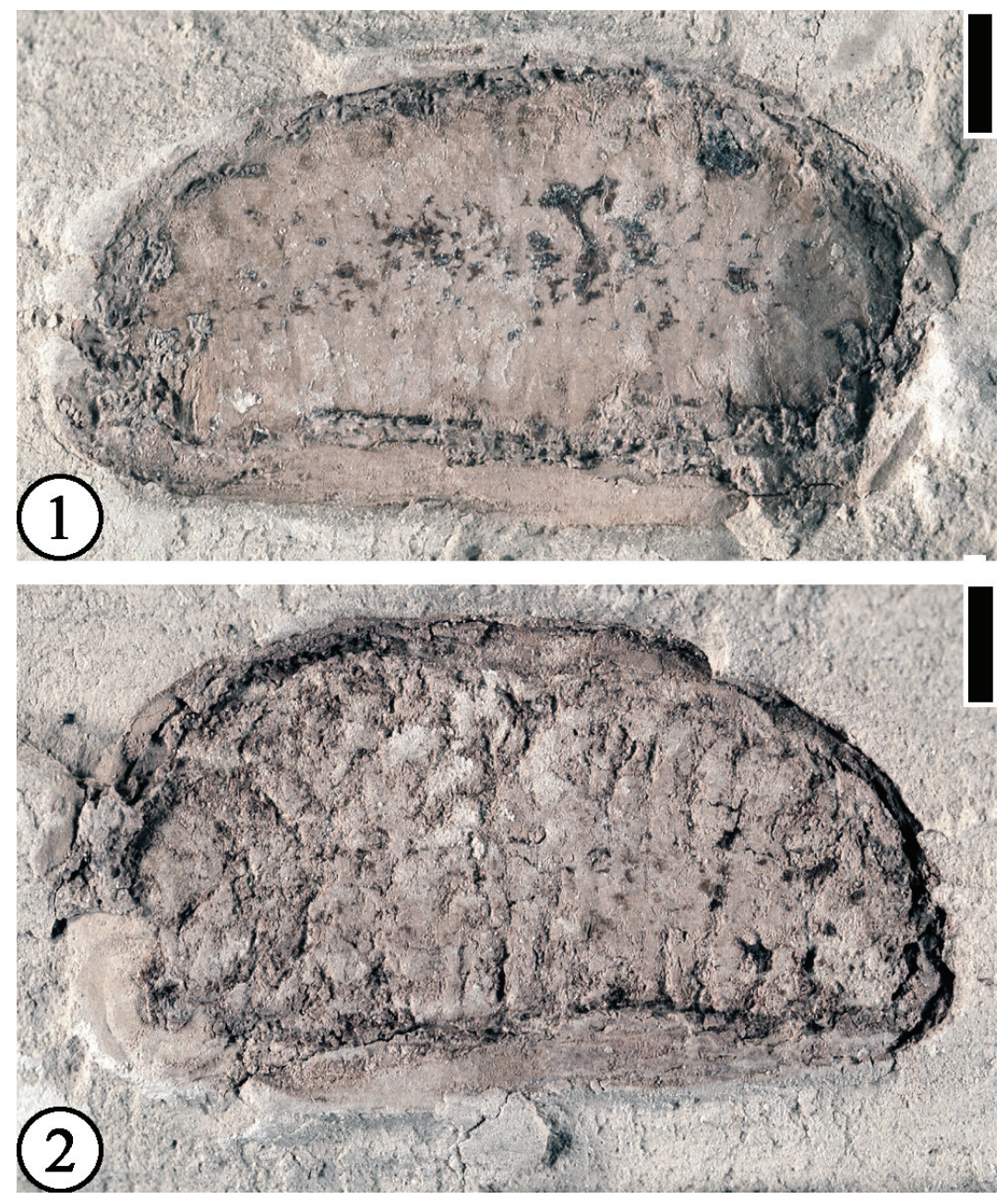

FIGURE 4. Anonaspermum robertsi (Berry) Wang, Blanchard, and Dilcher: 1-2) UF15738-060635. Part and counterpart of a specimen showing reniform seed, transverse endosperm ruminations, and thick testa. Scale bar equals 3 $\mathrm{mm}$. 
TABLE 1. All taxa/morphotypes reported from the Bovay and Bolden localities in northern Mississippi, and the Warman locality in western Tennessee, USA (Wang et al., 2013). The table also lists each taxon/morphotype's organ type, proposed modern affinity, and its figure numbers in this paper and in Wang et al. (2013). "+" indicates a taxon/morphotype is present at a locality.

\begin{tabular}{|c|c|c|c|c|c|c|c|}
\hline $\begin{array}{l}\text { Proposed modern } \\
\text { affinity }\end{array}$ & Taxa/morphotypes & $\begin{array}{c}\text { Figure } \\
\text { numbers in } \\
\text { this paper }\end{array}$ & $\begin{array}{l}\text { Figure numbers in } \\
\text { Wang et al. (2013) }\end{array}$ & Organ type & Warman & Bovay & Bolden \\
\hline Lauraceae & $\begin{array}{l}\text { Lauroflorum } \\
\text { warmanensis Wang, } \\
\text { Blanchard, and Dilcher, } \\
2013\end{array}$ & & figure 3 & flower & + & & \\
\hline \multirow[t]{2}{*}{ Annonaceae } & $\begin{array}{l}\text { Anonaspermum robertsi } \\
\text { (Berry) Wang, } \\
\text { Blanchard, and Dilcher, } \\
2013\end{array}$ & Figure 4 & figure $4.1-3,4.5-8$ & seed & + & & + \\
\hline & $\begin{array}{l}\text { Anonaspermum } \\
\text { warmanensis Wang, } \\
\text { Blanchard, and Dilcher, } \\
2013\end{array}$ & & figure 4.4 & seed & + & & \\
\hline Magnoliaceae & cf. Magnolia sp. & & figure 5 & seed & + & & \\
\hline Araceae & $\begin{array}{l}\text { cf. Acorites heeri Crepet, } \\
1978\end{array}$ & & figure 6 & inflorescence & + & & \\
\hline Altingiaceae & $\begin{array}{l}\text { Claiborne Altingiaceae } \\
\text { Infructescence Type } 1\end{array}$ & & figure 7 & infructescence & + & & \\
\hline \multirow[t]{2}{*}{ Hamamelidaceae } & $\begin{array}{l}\text { Corylopsis grotei Wang, } \\
\text { Blanchard, and Dilcher, } \\
2013\end{array}$ & & figure 8 & seed & + & & \\
\hline & Hamamelis sp. & & figure 9 & seed & + & & \\
\hline Euphorbiaceae & $\begin{array}{l}\text { Hippomaneoidea } \\
\text { warmanensis Crepet } \\
\text { and Daghlian, } 1982\end{array}$ & & figure 20 & inflorescence & + & & \\
\hline Malpighiaceae & $\begin{array}{l}\text { Eoglandulosa } \\
\text { warmanensis Taylor and } \\
\text { Crepet, } 1987\end{array}$ & & figure 21 & flower & + & & \\
\hline Salicaceae & cf. Populus sp. & Figure 13 & & fruit & & & + \\
\hline \multirow[t]{8}{*}{ Fabaceae } & $\begin{array}{l}\text { Caesalpinia } \\
\text { claibornensis } \\
\text { Herendeen and Dilcher, } \\
1991\end{array}$ & & figure $13.4-5$ & fruit & + & & \\
\hline & $\begin{array}{l}\text { Crudia grahamiana } \\
\text { Herendeen and Dilcher, } \\
\text { 1990a }\end{array}$ & & figure 13.6 & fruit & + & & \\
\hline & $\begin{array}{l}\text { Diplotropis claibornensis } \\
\text { Herendeen and Dilcher, } \\
\text { 1990b }\end{array}$ & & figure 14.1 & fruit & + & & \\
\hline & $\begin{array}{l}\text { Eliasofructus } \\
\text { claibornensis } \\
\text { Herendeen and Dilcher, } \\
\text { 1990c }\end{array}$ & & figure 14.2 & fruit & + & & \\
\hline & $\begin{array}{l}\text { Eomimosoidea plumosa } \\
\text { Crepet and Dilcher, } \\
1977\end{array}$ & & figures $10-11$ & inflorescence & + & & \\
\hline & Ormosia sp. & & figure $14.5-6$ & fruit & + & & \\
\hline & $\begin{array}{l}\text { Protomimosoidea } \\
\text { buchananensis Crepet } \\
\text { and Taylor, } 1986\end{array}$ & Figures 5-7 & figure 12 & flower & + & + & \\
\hline & Swartzia sp. & & figure 13.1 & fruit & + & & \\
\hline
\end{tabular}


TABLE 1 (continued).

\begin{tabular}{|c|c|c|c|c|c|c|c|}
\hline $\begin{array}{l}\text { Proposed modern } \\
\text { affinity }\end{array}$ & Taxa/morphotypes & $\begin{array}{c}\text { Figure } \\
\text { numbers in } \\
\text { this paper }\end{array}$ & $\begin{array}{l}\text { Figure numbers in } \\
\text { Wang et al. (2013) }\end{array}$ & Organ type & Warman & Bovay & Bolden \\
\hline & cf. Acrocarpus sp. & Figure 8 & & fruit & & + & \\
\hline & cf. Erythrophleum sp. & & figure 13.2 & fruit & + & & \\
\hline & $\begin{array}{l}\text { cf. Gleditsia? } \\
\text { mississippiensis (Berry) } \\
\text { Berry, } 1930\end{array}$ & Figure 9 & figure 14.3 & fruit & + & & + \\
\hline & $\begin{array}{l}\text { cf. Leguminosites } \\
\text { phyllocarpoides Berry, } \\
1930\end{array}$ & & figure 13.3 & fruit & + & & \\
\hline & $\begin{array}{l}\text { Claiborne Fabaceae } \\
\text { Floral Type } 1\end{array}$ & Figure 11 & & flower & & + & \\
\hline & $\begin{array}{l}\text { Claiborne Fabaceae } \\
\text { Floral Type } 2\end{array}$ & Figure 12 & & flower & & + & + \\
\hline & $\begin{array}{l}\text { "Short, broad winged } \\
\text { fruit" }\end{array}$ & Figure 10 & & fruit & & + & + \\
\hline & "Thick walled fruit" & & figure 14.4 & fruit & + & & \\
\hline \multirow[t]{7}{*}{ Fagaceae } & $\begin{array}{l}\text { Quercus oligocenensis } \\
\text { Daghlian and Crepet, } \\
1983\end{array}$ & & figure 15 & $\begin{array}{c}\text { staminate } \\
\text { inflorescences }\end{array}$ & + & & \\
\hline & $\begin{array}{l}\text { cf. Trigonobalanoidea } \\
\text { americana Crepet and } \\
\text { Nixon, } 1989\end{array}$ & Figure 14 & & infructescence & & + & \\
\hline & $\begin{array}{l}\text { Claiborne Fagaceae } \\
\text { Fruit Type } 1\end{array}$ & & figure $16.1-2$ & fruits & + & & \\
\hline & $\begin{array}{l}\text { Claiborne Fagaceae } \\
\text { Fruit Type } 2\end{array}$ & & figure 16.3 & fruit & + & & \\
\hline & $\begin{array}{l}\text { Claiborne Fagaceae } \\
\text { Fruit Type } 3\end{array}$ & Figure $15.1-3$ & figure 17.4 & fruit & + & & \\
\hline & $\begin{array}{l}\text { Claiborne Fagaceae } \\
\text { Fruit Type } 4\end{array}$ & Figure 16 & & fruit & & + & \\
\hline & $\begin{array}{l}\text { Claiborne Fagaceae } \\
\text { Fruit Type } 5\end{array}$ & Figure 15.5 & figure $17.1-3$ & fruit & + & & \\
\hline \multirow[t]{2}{*}{ Juglandaceae } & $\begin{array}{l}\text { Eokachyra aeolius } \\
\text { Crepet, Dilcher and } \\
\text { Potter, } 1975\end{array}$ & & figure 18 & inflorescence & + & & \\
\hline & $\begin{array}{l}\text { Paleooreomunnea } \\
\text { stoneana Dilcher, Potter } \\
\text { and Crepet, } 1976\end{array}$ & & figure 19 & fruit & + & & \\
\hline Moraceae & $\begin{array}{l}\text { Cornerocarpon } \\
\text { copiosum Grote, } 1989\end{array}$ & & figures 22,23 & fruit & + & & \\
\hline Rhamnaceae & $\begin{array}{l}\text { "Solanites" pusillus } \\
\text { Berry, } 1930\end{array}$ & Figures $17-18$ & figure 35 & flower & + & + & + \\
\hline Sapindaceae & $\begin{array}{l}\text { Bridgesia bovayensis } \\
\text { Manchester and } \\
\text { O'Leary, } 2010\end{array}$ & Figure 19 & & fruit & & + & \\
\hline \multirow[t]{4}{*}{ Theaceae } & $\begin{array}{l}\text { Andrewsiocarpon } \\
\text { henryense Grote and } \\
\text { Dilcher, } 1989\end{array}$ & & figure 27 & fruit & + & & \\
\hline & $\begin{array}{l}\text { Gordonia warmanensis } \\
\text { Grote and Dilcher, } 1989\end{array}$ & Figure 20 & figure 24 & fruit & + & + & \\
\hline & cf. Gordonia sp. 1 & & figure 25 & flower & + & & \\
\hline & cf. Gordonia sp. 2 & & figure 26 & flower & + & & \\
\hline
\end{tabular}


TABLE 1 (continued).

\begin{tabular}{|c|c|c|c|c|c|c|c|}
\hline $\begin{array}{l}\text { Proposed modern } \\
\text { affinity }\end{array}$ & Taxa/morphotypes & $\begin{array}{c}\text { Figure } \\
\text { numbers in } \\
\text { this paper }\end{array}$ & $\begin{array}{l}\text { Figure numbers in } \\
\text { Wang et al. (2013) }\end{array}$ & Organ type & Warman & Bovay & Bolden \\
\hline Icacinaceae & $\begin{array}{l}\text { cf. Natsiatum wilcoxiana } \\
\text { (Berry) Stull, Moore and } \\
\text { Manchester, } 2011\end{array}$ & Figure 21 & & endocarp & & + & \\
\hline Eucommiaceae & $\begin{array}{l}\text { Eucommia eocenica } \\
\text { (Berry) Brown, } 1940\end{array}$ & Figure 22 & & fruit & & + & + \\
\hline Bignoniaceae & $\begin{array}{l}\text { Grotea warmanensis } \\
\text { Wang, Blanchard and } \\
\text { Dilcher, } 2013\end{array}$ & & figure 28.1 & fruit & + & & \\
\hline Oleaceae & $\begin{array}{l}\text { Fraxinus wilcoxiana } \\
\text { (Berry) Call and Dilcher, } \\
1992\end{array}$ & & figure 29 & fruit & + & & \\
\hline Caprifoliaceae & $\begin{array}{l}\text { Dipelta bovayensis sp. } \\
\text { nov. }\end{array}$ & Figure 23 & & fruit & & + & \\
\hline \multirow[t]{2}{*}{ Araliaceae } & $\begin{array}{l}\text { “Aralia” semina Berry, } \\
1930\end{array}$ & & figure 30 & seed & + & & \\
\hline & $\begin{array}{l}\text { Paleopanax boldensis } \\
\text { sp. nov. }\end{array}$ & Figure 24 & & fruit & & + & \\
\hline \multirow{23}{*}{$\begin{array}{l}\text { Angiosperm } \\
\text { incertae sedis - } \\
\text { flowers }\end{array}$} & $\begin{array}{l}\text { Antholithes wilcoxensis } \\
\text { Berry, } 1930\end{array}$ & & figure 34 & flower & + & & \\
\hline & $\begin{array}{l}\text { "Solanites" } \\
\text { sarachaformis Berry, } \\
1930\end{array}$ & Figure 26 & & flower & & + & \\
\hline & $\begin{array}{l}\text { cf. "Solanites" } \\
\text { saportanus (Berry) } \\
\text { Martínez-Millán, } 2010\end{array}$ & Figure 25 & & flower & & + & \\
\hline & Claiborne Floral Type 1 & & figure $36.1-2$ & flower & + & & \\
\hline & Claiborne Floral Type 2 & & figure $36.3-4$ & flower & + & & \\
\hline & Claiborne Floral Type 3 & & figure 37 & flower & + & & \\
\hline & Claiborne Floral Type 4 & & figure 38 & flower & + & & \\
\hline & Claiborne Floral Type 5 & Figure 27 & figure 39 & flower & + & & + \\
\hline & Claiborne Floral Type 6 & & figure 40 & flower & + & & \\
\hline & Claiborne Floral Type 7 & Figure 28 & & flower & & + & \\
\hline & Claiborne Floral Type 8 & Figure 29 & & flower & & + & \\
\hline & Claiborne Floral Type 9 & Figure 30 & & flower & & + & \\
\hline & Claiborne Floral Type 10 & Figure 31 & & flower & & + & \\
\hline & Claiborne Floral Type 11 & Figure 32 & & flower & & + & \\
\hline & Claiborne Floral Type 12 & Figure 33 & & flower & & & + \\
\hline & Claiborne Floral Type 13 & Figure 34 & & flower & & + & \\
\hline & Claiborne Floral Type 14 & Figure 35 & & flower & & & + \\
\hline & Claiborne Floral Type 15 & Figure 36 & & flower & & + & \\
\hline & Claiborne Floral Type 16 & Figure 37 & & flower & & + & \\
\hline & Claiborne Floral Type 17 & Figure 38 & & flower & & & + \\
\hline & Claiborne Floral Type 18 & Figure 39 & & flower & & + & \\
\hline & Claiborne Floral Type 19 & Figure 40 & & petal? & & + & \\
\hline & Claiborne Floral Type 20 & Figure 41 & & stamens & & + & \\
\hline
\end{tabular}


TABLE 1 (continued).

\begin{tabular}{|c|c|c|c|c|c|c|c|}
\hline $\begin{array}{l}\text { Proposed modern } \\
\text { affinity }\end{array}$ & Taxa/morphotypes & $\begin{array}{c}\text { Figure } \\
\text { numbers in } \\
\text { this paper }\end{array}$ & $\begin{array}{l}\text { Figure numbers in } \\
\text { Wang et al. (2013) }\end{array}$ & Organ type & Warman & Bovay & Bolden \\
\hline \multirow{8}{*}{$\begin{array}{l}\text { Angiosperm } \\
\text { incertae sedis - } \\
\text { infructescences }\end{array}$} & "Sparganium" sp. & Figure 42 & figure 49 & infructescence & + & + & \\
\hline & $\begin{array}{l}\text { Claiborne } \\
\text { Infructescence Type } 1\end{array}$ & & figure 31 & infructescence & + & & \\
\hline & $\begin{array}{l}\text { Claiborne } \\
\text { Infructescence Type } 2\end{array}$ & & figure 32 & infructescence & + & & \\
\hline & $\begin{array}{l}\text { Claiborne } \\
\text { Infructescence Type } 3\end{array}$ & & figure 33 & infructescence & + & & \\
\hline & $\begin{array}{l}\text { Claiborne } \\
\text { Infructescence Type } 4\end{array}$ & Figure 43 & & infructescence & & + & \\
\hline & $\begin{array}{l}\text { Claiborne } \\
\text { Infructescence Type } 5\end{array}$ & Figure 44 & & infructescence & & + & \\
\hline & $\begin{array}{l}\text { Claiborne } \\
\text { Infructescence Type } 6\end{array}$ & Figure 45 & & infructescence & & + & \\
\hline & $\begin{array}{l}\text { Claiborne } \\
\text { Infructescence Type } 7\end{array}$ & Figure 46 & & infructescence & & & + \\
\hline \multirow{13}{*}{$\begin{array}{l}\text { Angiosperm } \\
\text { incertae sedis - } \\
\text { fruits and seeds }\end{array}$} & $\begin{array}{l}\text { Carpolithus boldensis } \\
\text { sp. nov. }\end{array}$ & Figure 47 & & seed & & & + \\
\hline & $\begin{array}{l}\text { Carpolithus collinsi } \\
\text { (Berry) Wang, } \\
\text { Blanchard, and Dilcher, } \\
2013\end{array}$ & & figure 41 & fruit & + & & \\
\hline & $\begin{array}{l}\text { Carpolithus complanata } \\
\text { (Lesquereux) Wang, } \\
\text { Blanchard, and Dilcher, } \\
2013\end{array}$ & & figure 42 & seed & + & & \\
\hline & $\begin{array}{l}\text { Carpolithus } \\
\text { prangosoides Berry, } \\
1916 \mathrm{~b}\end{array}$ & & figure 43 & fruit & + & & \\
\hline & $\begin{array}{l}\text { Carpolithus sophorites } \\
\text { Berry, } 1916 \mathrm{~b}\end{array}$ & & figure 44 & seed & + & & \\
\hline & $\begin{array}{l}\text { Carpolithus } \\
\text { warmanensis Wang, } \\
\text { Blanchard, and Dilcher, } \\
2013\end{array}$ & & figure 45 & fruit & + & & \\
\hline & $\begin{array}{l}\text { Palmocarpon wilcoxiana } \\
\text { (Berry) Wang, } \\
\text { Blanchard, Dilcher, } 2013\end{array}$ & Figure 55 & figure 47,48 & fruit & + & + & \\
\hline & $\begin{array}{l}\text { “Acer” knowltoni (Berry) } \\
\text { Brown, } 1940\end{array}$ & Figure 49 & & fruit & & + & + \\
\hline & $\begin{array}{l}\text { "Copaifera" yeguana } \\
\text { Berry, } 1915\end{array}$ & & figure 46 & fruit & + & & \\
\hline & cf. Saportaspermum sp. & Figure 48 & & seed & & + & \\
\hline & $\begin{array}{l}\text { Claiborne Fruit/Seed } \\
\text { Type } 1\end{array}$ & & figure 50 & fruit/seed & + & & \\
\hline & $\begin{array}{l}\text { Claiborne Fruit/Seed } \\
\text { Type } 2\end{array}$ & & figure 51 & fruit/seed & + & & \\
\hline & $\begin{array}{l}\text { Claiborne Fruit/Seed } \\
\text { Type } 3\end{array}$ & & figure 52 & fruit/seed & + & & \\
\hline
\end{tabular}


TABLE 1 (continued).

\begin{tabular}{|c|c|c|c|c|c|c|c|}
\hline $\begin{array}{l}\text { Proposed modern } \\
\text { affinity }\end{array}$ & Taxa/morphotypes & $\begin{array}{c}\text { Figure } \\
\text { numbers in } \\
\text { this paper }\end{array}$ & $\begin{array}{l}\text { Figure numbers in } \\
\text { Wang et al. (2013) }\end{array}$ & Organ type & Warman & Bovay & Bolden \\
\hline & $\begin{array}{l}\text { Claiborne Fruit/Seed } \\
\text { Type } 4\end{array}$ & & figure 53 & fruit/seed & + & & \\
\hline & $\begin{array}{l}\text { Claiborne Fruit/Seed } \\
\text { Type } 5\end{array}$ & & figure 54 & fruit/seed & + & & \\
\hline & $\begin{array}{l}\text { Claiborne Fruit/Seed } \\
\text { Type } 6\end{array}$ & Figure 50 & & fruit/seed & & + & \\
\hline & $\begin{array}{l}\text { Claiborne Fruit/Seed } \\
\text { Type } 7\end{array}$ & Figure 51 & & fruit/seed & & + & \\
\hline & $\begin{array}{l}\text { Claiborne Fruit/Seed } \\
\text { Type } 8\end{array}$ & Figure 52 & & fruit/seed & & + & \\
\hline & $\begin{array}{l}\text { Claiborne Fruit/Seed } \\
\text { Type } 9\end{array}$ & Figure 53 & & fruit/seed & & + & \\
\hline & $\begin{array}{l}\text { Claiborne Fruit/Seed } \\
\text { Type } 10\end{array}$ & Figure 54 & & fruit/seed & & + & \\
\hline Plant incertae sedis & Equisetum? & & figure 55 & unknown & + & & \\
\hline \multirow[t]{4}{*}{ Undetermined } & $\begin{array}{l}\text { Claiborne Undetermined } \\
\text { Structure } 1\end{array}$ & Figure 56 & & unknown & & + & \\
\hline & $\begin{array}{l}\text { Claiborne Undetermined } \\
\text { Structure } 2\end{array}$ & Figure 57 & & unknown & & + & \\
\hline & $\begin{array}{l}\text { Claiborne Undetermined } \\
\text { Structure } 3\end{array}$ & Figure 58 & & unknown & & + & \\
\hline & $\begin{array}{l}\text { Claiborne Undetermined } \\
\text { Structure } 4\end{array}$ & Figure 59 & & unknown & & + & \\
\hline $\begin{array}{l}\text { Number of taxa/ } \\
\text { morphotypes from } \\
\text { each locality }\end{array}$ & & & & & 62 & 43 & 14 \\
\hline $\begin{array}{l}\text { Number of taxa/ } \\
\text { morphotypes from } \\
\text { all three localities }\end{array}$ & & & & & 106 & & \\
\hline
\end{tabular}

Description. Laterally preserved reniform seed ca $3.5 \mathrm{~cm}$ long and $1.3 \mathrm{~cm}$ wide; transverse endosperm ruminations present. Testa ca $2 \mathrm{~mm}$ thick.

Number of specimens examined. 1. UF15738060635.

Remarks. The seed from the Bolden locality is larger, and the seed testa is thicker than Anonaspermum robertsi specimens from the Warman clay pit, Tennessee (Wang et al., 2013). The Bolden specimen lacks the spiniform endosperm ruminations, which are characteristic of the second Anonaspermum species from the Warman clay pit, $A$. warmanensis Wang, Blanchard, and Dilcher (Wang at al., 2013).

Order FABALES Bromhead, 1838

Family FABACEAE Lindley, 1846
Genus PROTOMIMOSOIDEA Crepet and Taylor, 1986

Type species. Protomimosoidea buchananensis Crepet and Taylor, 1986, here designated.

Protomimosoidea buchananensis Crepet and Taylor, 1986

(Figures 5, 6, 7)

* 1986 Protomimosoidea buchananensis Crepet and Taylor, p. 555, figs. 1-22.

v. 2013 Protomimosoidea buchananensis Crepet and Taylor; Wang, Blanchard, and Dilcher, p. 15, fig. 12.

Description. Flowers ca 3-4 mm long and 2-4 mm wide (excluding filaments and pedicel) with up to 10 stamens. Filaments exserted, up to $5 \mathrm{~mm}$ long and often of unequal length. Anthers ca $0.75-1 \mathrm{~mm}$ long and $0.5 \mathrm{~mm}$ wide. Perianth parts usually three, 


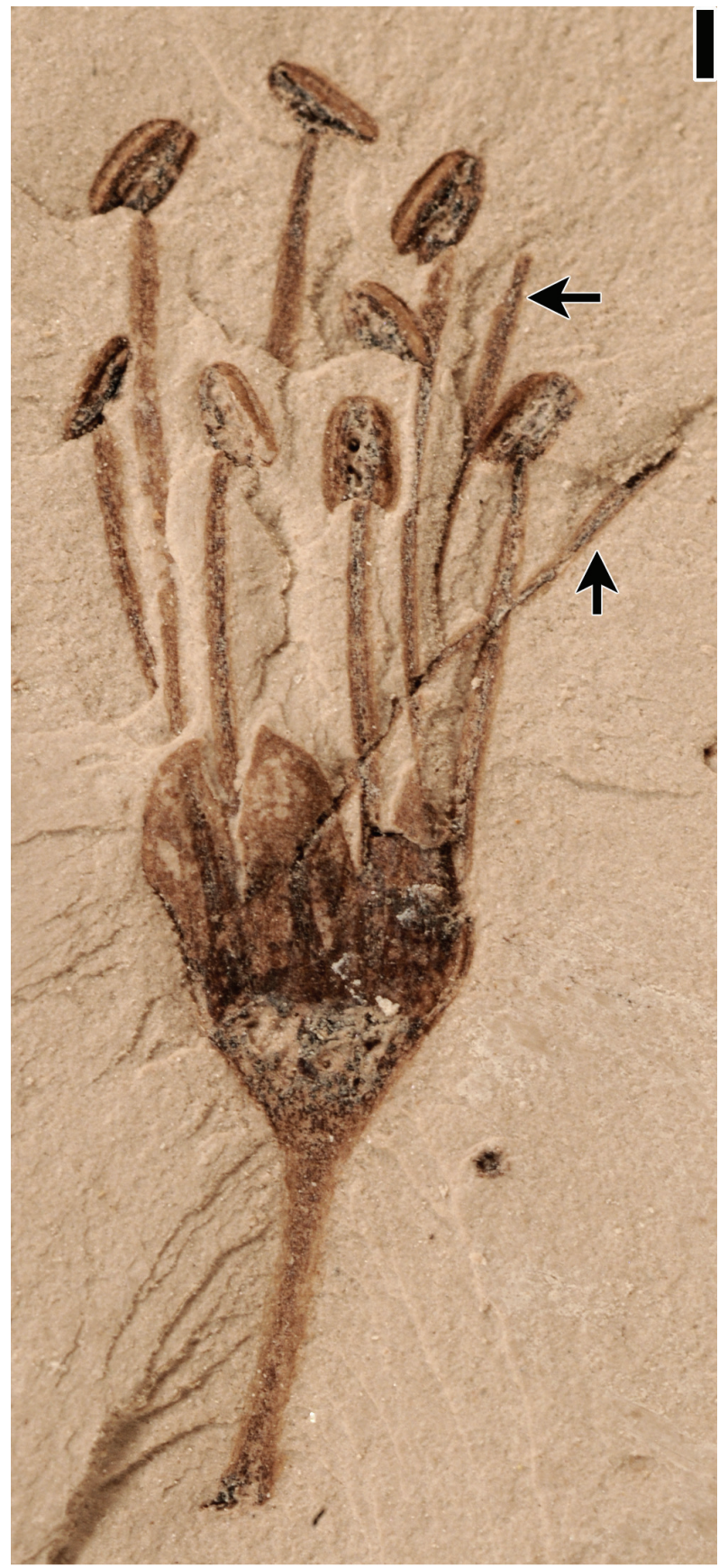

FIGURE 5. Protomimosoidea buchananensis Crepet and Taylor, 1986, UF15737-026430. Flower showing at least three valvate petals, 10 stamens, and dorsifixed anthers. Note two stamens with missing anthers (indicated by arrows). Scale bar equals $0.5 \mathrm{~mm}$.

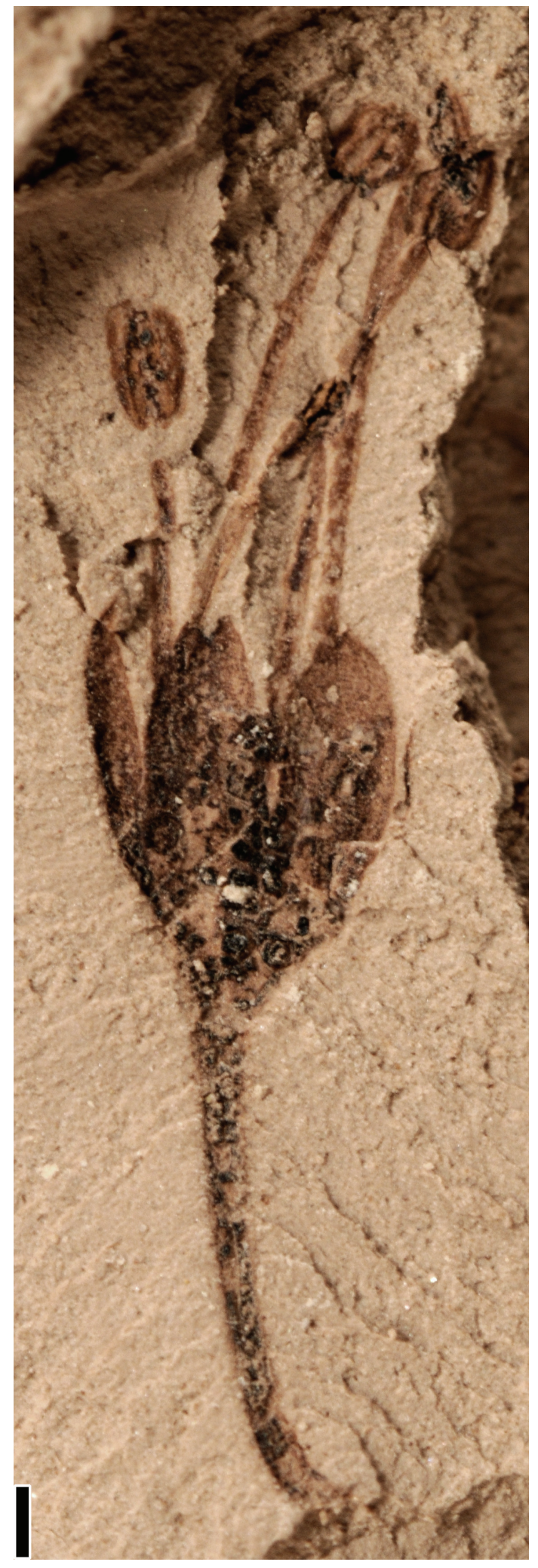

FIGURE 6. Protomimosoidea buchananensis Crepet and Taylor, 1986, UF15737-060709. Specimen showing three petals and five stamens. Scale bar equals 0.5 $\mathrm{mm}$. 


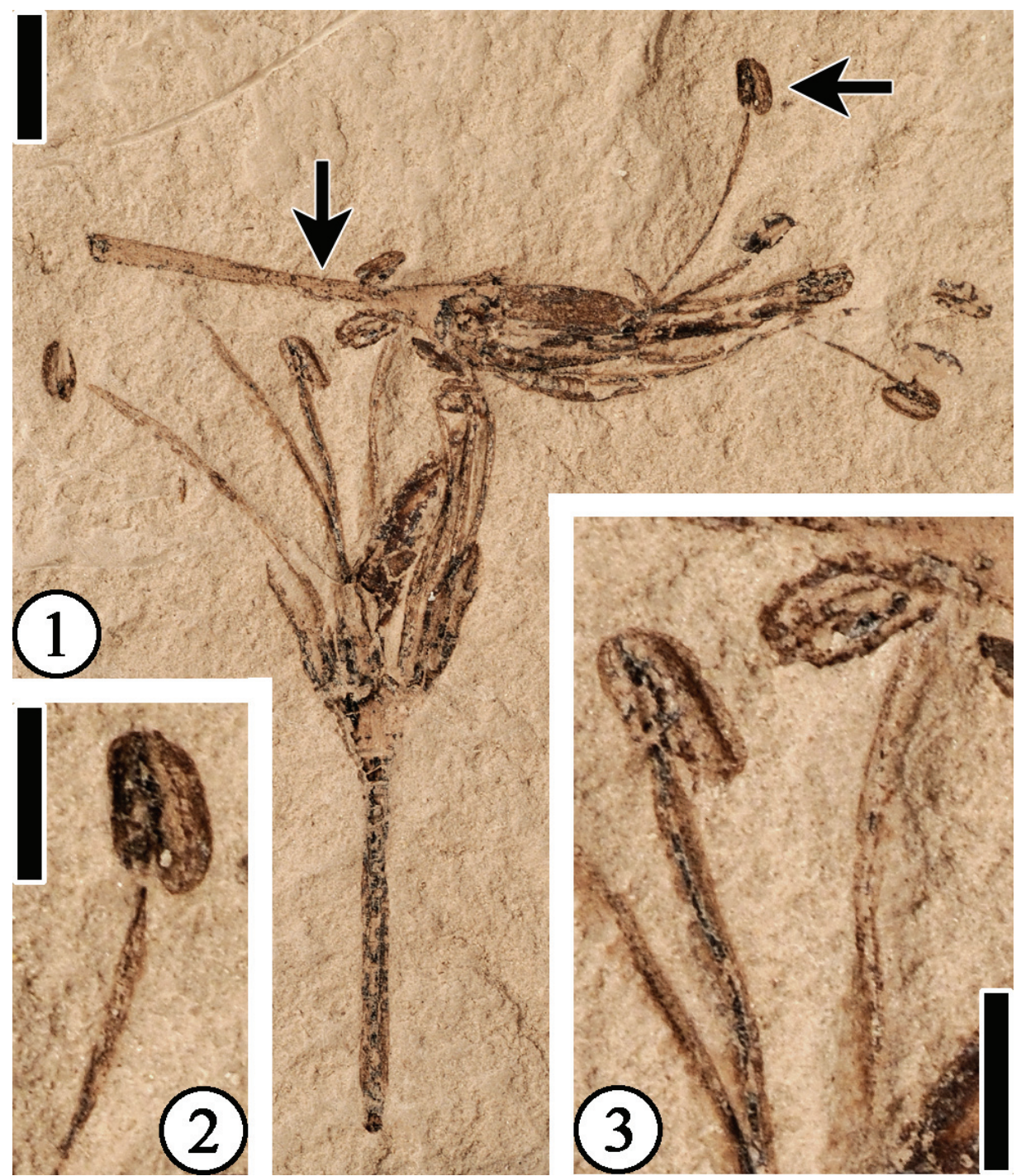

FIGURE 7. Protomimosoidea buchananensis Crepet and Taylor, 1986: 1) UF15737-027593. Two flowers with attached anthers. Note long pedicel. Scale bar equals $2 \mathrm{~mm}$; 2) Enlargement of Figure 7.1 (indicated by upper arrow) to show anther. Scale bar equals $1 \mathrm{~mm}$; 3) Enlargement of Figure 7.1 (indicated by left arrow) to show anthers and filaments. Scale bar equals $1 \mathrm{~mm}$.

triangular, ca $2 \mathrm{~mm}$ long, and $1 \mathrm{~mm}$ wide, attached to the rim of the receptacle. Receptacle ca $2 \mathrm{~mm}$ wide and $1 \mathrm{~mm}$ long. Pedicel ca $0.3 \mathrm{~mm}$ wide and up to $6 \mathrm{~mm}$ long.

Number of specimens examined. 4. UF15737026430, 027593, 060709.

Remarks. Flowers of Protomimosoidea buchananensis Crepet and Taylor, 1986 are common from the Warman, Puryear and Buchanan localities of the Claiborne Group in Tennessee (Crepet, 1979; Crepet and Taylor, 1985, 1986; Wang et al., 2013). Compared with flowers from other Claiborne localities, specimens from the Bovay locality are better preserved and they are probably more mature than those described from the Warman locality. One complete flower (Figure 5) has 10 stamens, five of which have shorter filaments that are only $67 \%$ of the length of the other five stamens.

Berry (1916b, p. 322, plate 96, figures 1-5) described a similar flower from a locality $2.4 \mathrm{~km}$ west of Grand Junction in Fayette County, Tennessee. He suggested that this specimen, assigned to Combretanthites eocenica, is closely related to the Combretaceae rather than the Mimosoideae because of its inferior ovary. If, however, the ovary is superior within a hypanthium, Berry's specimen could belong in Protomimosoidea. Crepet and Taylor (1986) did not include Berry's specimen in their study of primitive mimosoid flowers. Unfortunately, we are unable to locate the specimen described by 


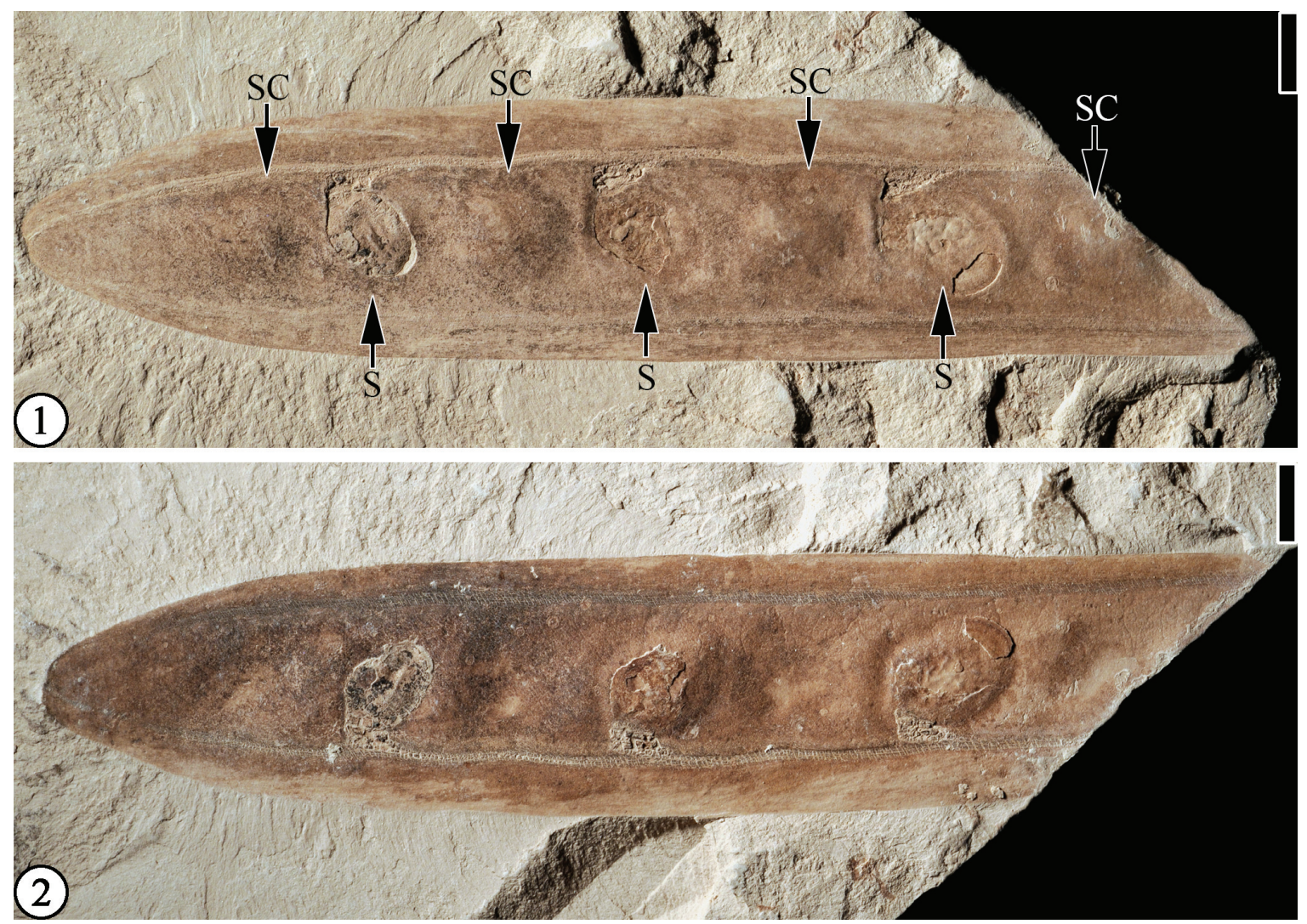

FIGURE 8. cf. Acrocarpus sp.: 1-2) UF15737-008276, 008276'. Part and counterpart of a specimen showing a single valve of a fruit with alternating outlines of three seeds (s) and four seed chambers (sc). Scale bar equals $5 \mathrm{~mm}$.

Berry (1916b) to further confirm or reject its assignment to the Combretaceae.

Genus ACROCARPUS Wight ex Arnott, 1838 cf. Acrocarpus sp.

(Figure 8)

v. 1992 cf. Acrocarpus sp. Herendeen, p. 89-90, figs. 18-20.

Description. "Fruit incomplete, $8.1^{+} \mathrm{cm}$ long, 1.8 $\mathrm{cm}$ wide; placental suture winged, $3-4 \mathrm{~mm}$ wide; nonplacental suture winged, 2-3 $\mathrm{mm}$ wide; apex rounded; base not preserved; seeds $6^{+}$, symmetrical, $7.5 \mathrm{~mm}$ long, $5 \mathrm{~mm}$ wide, transverse to slightly oblique; fruits dehiscent, valves not twisting" (Herendeen, 1992, p. 89-90).

Number of specimens examined. 1. UF15737008276.

Remarks. This is the specimen from the Bovay clay pit described by Herendeen (1992). He suggested that this fossil fruit is most similar to Acrocarpus in size, structure, and seed shape. However, fruits of extant Acrocarpus are narrowly winged along the nonplacental suture. It will be significant if this fossil fruit is confirmed to belong to extant Acrocarpus, because this genus consists of one or two species of large tropical trees found only in India, Indonesia (Sumatra), and Thailand (Allen and Allen, 1981; Polhill and Vidal, 1981).

Genus GLEDITSIA Linnaeus, 1742 cf. Gleditsia? mississippiensis Berry, 1916b

(Figure 9)

* 1916 Cassia mississippiensis Berry, p. 235; pl. 51, figs. 10, 11.

* 1930 Gleditsia? mississippiensis (Berry) Berry, p. 82 , pl. 50 , figs. $2-4$.

v*1992 cf. Gleditsia? mississippiensis Herendeen, p. 128-129, figs. 225-230.

Description. "The fruits are 1.5-1.9 cm long; 0.9$1.0 \mathrm{~cm}$ wide; stipitate, $2-5 \mathrm{~mm}$ long; round, oblong or ovate with rounded apex and base; valves coriaceous, possibly thickened over seed chamber; seed possibly one; calyx lobes five, rounded, reflexed" (Herendeen, 1992, p. 128-129; see also Wang et al., 2013).

Number of specimens examined. 1. UF15738008791. 



FIGURE 9. cf. Gleditsia? mississippiensis Berry, 1916b: 1-2) UF15738-008791, 008791'. Part and counterpart of a specimen showing stipe (s), calyx (c), calyx lobes (cl), and pod with rounded apex. Scale bar equals $2 \mathrm{~mm}$.

Remarks. This specimen was described by Herendeen (1992, p. 128-129, figures 229, 230). He considered it to be similar to fruits described by Berry (1916b, 1930) as Cassia mississippiensis and Gleditsia? mississippiensis but differing in size, shape, and calyx structure.

\section{"Short, broad winged fruit"}

(Figure 10)

v*1992 "Short, broad winged fruit", Herendeen, p. 129, figs. 231-238.

Description. "The fruits are $3.0-6.0+\mathrm{cm}$ long, $1.6-3.2 \mathrm{~cm}$ wide; apex rounded to attenuate; base abruptly rounded to attenuate; fruits stipitate, $5 \mathrm{~mm}$ long; margins straight to slightly constricted; nonvascularized wing on placental suture, up to $2 \mathrm{~mm}$ wide; seeds $1-2$, possibly round; valves thin and membranous, venous; orientation of major veins variable, from approximately perpendicular to oblique; calyx open, radially symmetrical" (Herendeen, 1992, p. 129).

Number of specimens examined. 4. UF15737008279; UF15738-008790.

Remarks. Herendeen (1992) described eight specimens from the Puryear locality, Tennessee, and Bolden and Bovay localities, Mississippi. The two specimens illustrated in Figure 10 were also illustrated by Herendeen (1992, figures 236, 237). $\mathrm{He}$ did not feel that there was sufficient detail to allow assignment of these fruits to a specific taxon within the Fabaceae. Herendeen (1992) noted that the open radially symmetrical calyx is suggestive of 

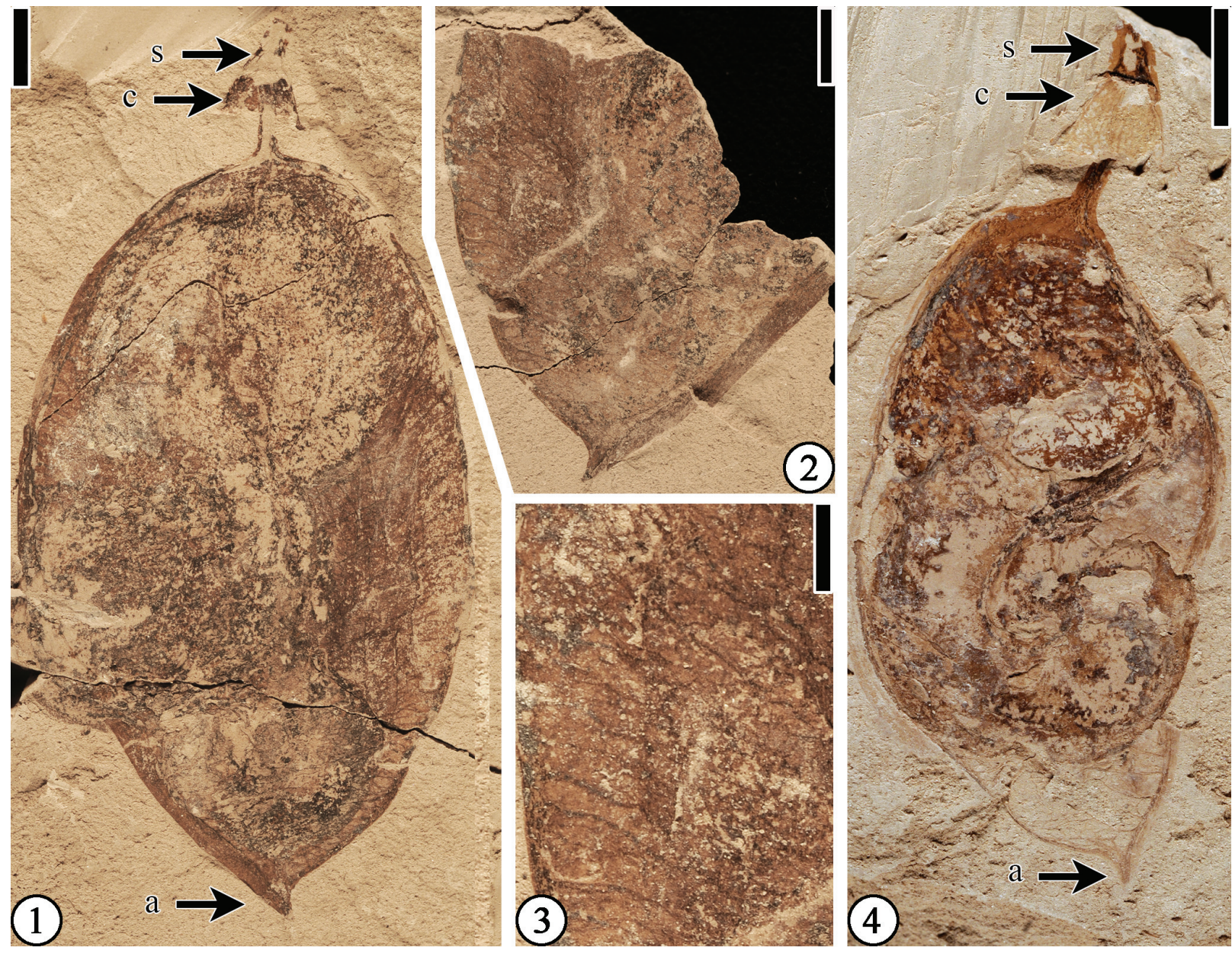

FIGURE 10. "Short, broad winged fruit" (1-3) UF15737-008279: 1) Showing stipe (s), calyx (c), and pod with attenuate apex (a). Scale bar equals $5 \mathrm{~mm}$; 2) Counterpart of UF15737-008279. Scale bar equals $5 \mathrm{~mm}$; 3) Enlargement of Figure 10.2 to show valve venation. Scale bar equals $2 \mathrm{~mm}$; 4) 15738-008790. Showing stipe (s), calyx (c), and pod with attenuate apex (a). Scale bar equals $5 \mathrm{~mm}$.

caesalpinioid, mimosoid, or basal papilionoid (Sophoreae) genera, and that the bilateral symmetry of some papilionoid groups may be difficult to perceive in a lateral view of a compressed calyx.

\section{Claiborne Fabaceae Floral Type 1}

(Figure 11)

Description. Laterally preserved flower $2 \mathrm{~cm}$ long. Pedicel short, broken. Calyx rounded, ca $3 \mathrm{~mm}$ long and $3 \mathrm{~mm}$ wide. The three visible sepals connate except for ca $1 \mathrm{~mm}$ at apices. Petals thin, not well preserved, at least two, one of which is longer. Expanding ovary present, $10 \mathrm{~mm}$ long and $2.5 \mathrm{~mm}$ wide, with an apical style about $1.5 \mathrm{~mm}$ long. One stamen present; filament ca $9 \mathrm{~mm}$ long, anther 1.5 $\mathrm{mm}$ long.

Number of specimens examined. 1. UF15737059328.
Remarks. The presence of a standard petal on this specimen suggests that it probably represents a zygomorphic papilionoid flower. This type of flower has been reported from the middle Eocene localities of Tennessee (Crepet, 1984; Crepet and Taylor, 1985; Friis and Crepet, 1987) and is often preserved with an expanding ovary (Crepet and Taylor, 1985).

\section{Claiborne Fabaceae Floral Type 2 \\ (Figure 12)}

Description. Laterally compressed flower(s) 7-10 $\mathrm{mm}$ long and up to $7 \mathrm{~mm}$ wide at the widest point; ovary ca $2 \mathrm{~mm}$ long and $2.5 \mathrm{~mm}$ wide, tapering to a pedicel $5-5.5 \mathrm{~mm}$ long and $1 \mathrm{~mm}$ wide. One style present, $2 \mathrm{~mm}$ long. Stamens numerous, filaments $1 \mathrm{~mm}$ long, anthers $0.5 \mathrm{~mm}$ in diameter. Petal 1 $\mathrm{mm}$ long and $1 \mathrm{~mm}$ wide, with at least four fine 


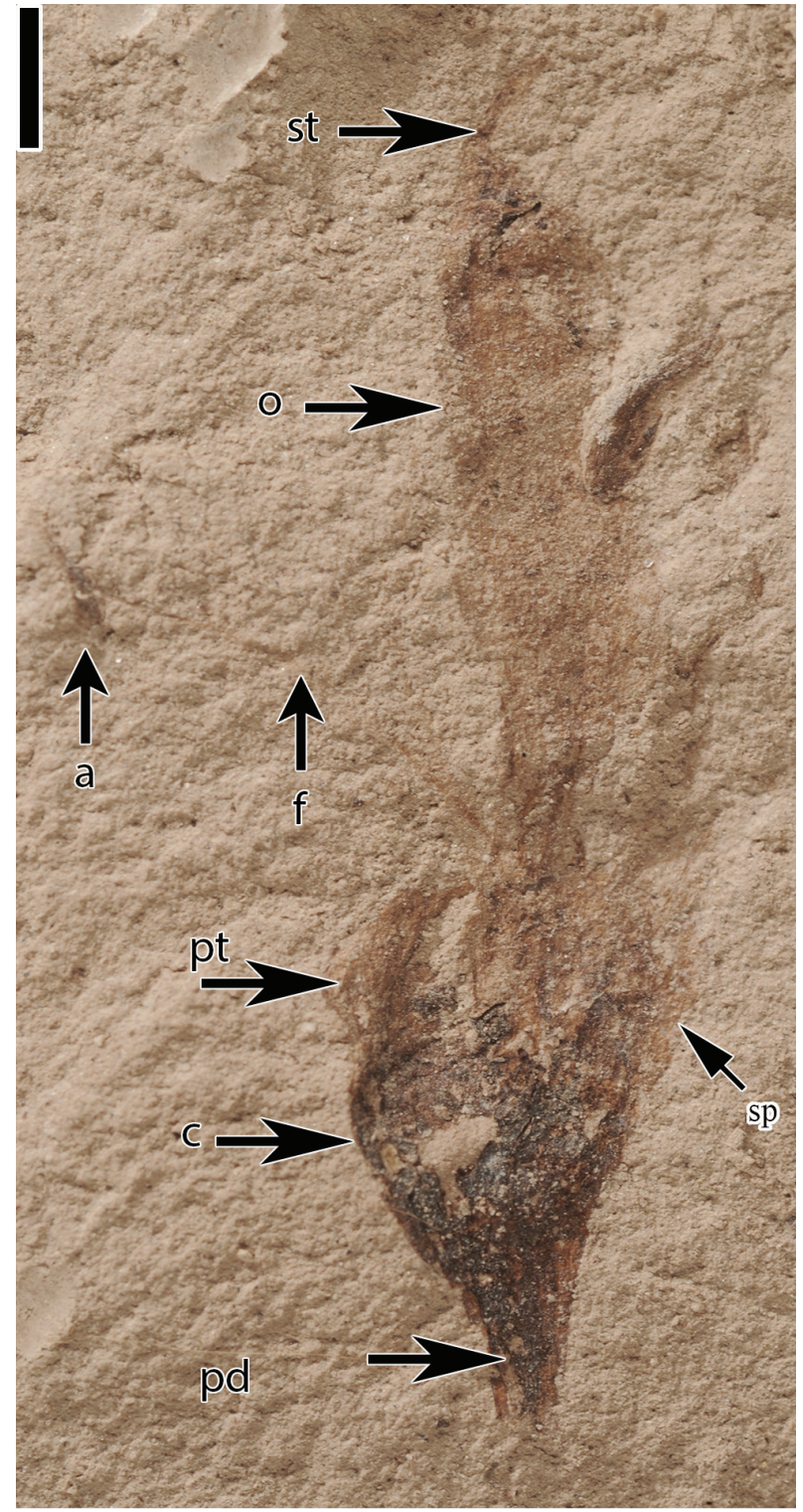

FIGURE 11. Claiborne Fabaceae Floral Type 1, UF15737-059328. Laterally preserved flower showing a short pedicel (pd), calyx (c), 2 petals (pt), standard petal (sp), expanding ovary (o) with an apical style (st), and a stamen with a filament (f) and an anther (a). Scale bar equals $2 \mathrm{~mm}$.

veins, recurved. Number of sepals and petals unknown.

Number of specimens examined. 4. UF15738008215; UF15737-059252, 059312.

Remarks. This floral type differs from Protomimosoidea buchananensis in having numerous stamens with short filaments rather than 10 stamens with long filaments. It differs from Claiborne Fabaceae Floral Type 1 in not having a zygomorphic floral structure. Table 2 summarizes the differences among Claiborne Fabaceae Floral Types 1 and 2, Protomimosoidea buchananensis, and Claiborne Floral Types 17 and 18.

\author{
Order MALPIGHIALES Jussieu ex von Berchtold \\ and Presl, 1820 \\ Family SALICACEAE de Mirbel, 1815 \\ Genus POPULUS Linnaeus, 1753 \\ cf. Populus sp. \\ (Figure 13)
}

Description. Vertically preserved dehisced capsule with four valves, each ca $3 \mathrm{~mm}$ long and 2.5 $\mathrm{mm}$ wide at the base. Apices acute. Valves attached to central portion ca $3.5 \mathrm{~mm}$ long and 2.5 mm wide.

Number of specimens examined. 1. UF15738008213.

Remarks. This vertically preserved specimen may represent a four-valved capsule or a partially preserved flower of Salicaceae (Boucher et al., 2003; Manchester et al., 2006). The central portion where the valves are attached probably represents the remains of the hypogenous perianth and the pedicel. According to Manchester et al. (2006), this feature distinguishes Populus and Pseudosalix Boucher, Manchester, and Judd from other members of the Salicaceae.

Leaves of Populus have been identified from the Bolden locality and also from the Cockfield Formation (Claiborne Group) at Wilbanks and Warman localities in Tennessee. Pseudosalix is not known from any southeastern USA Claiborne deposits.

Order FAGALES Engler, 1892

Family FAGACEAE Dumortier, 1829

Genus TRIGONOBALANOIDEA Crepet and Nixon, 1989

cf. Trigonobalanoidea americana Crepet and Nixon, 1989

(Figure 14)

Description. Immature pistillate infructescence, unbranched, with a slightly curved axis $3 \mathrm{~cm}$ long and $0.3 \mathrm{~mm}$ wide, bearing at least 32 alternately arranged immature fruits. Fruits sessile, $1.5 \mathrm{~mm}$ wide and up to $2 \mathrm{~mm}$ long, tapering toward the distal end. Two or three styles present.

Number of specimens examined. 1. UF15737059224.

Remarks. This specimen probably represents an immature infructescence of Trigonobalanoidea americana (Crepet and Nixon, 1989). However, the specimen is not well preserved. The demarcation of the cupule and fruit body is indistinct. One fruit 

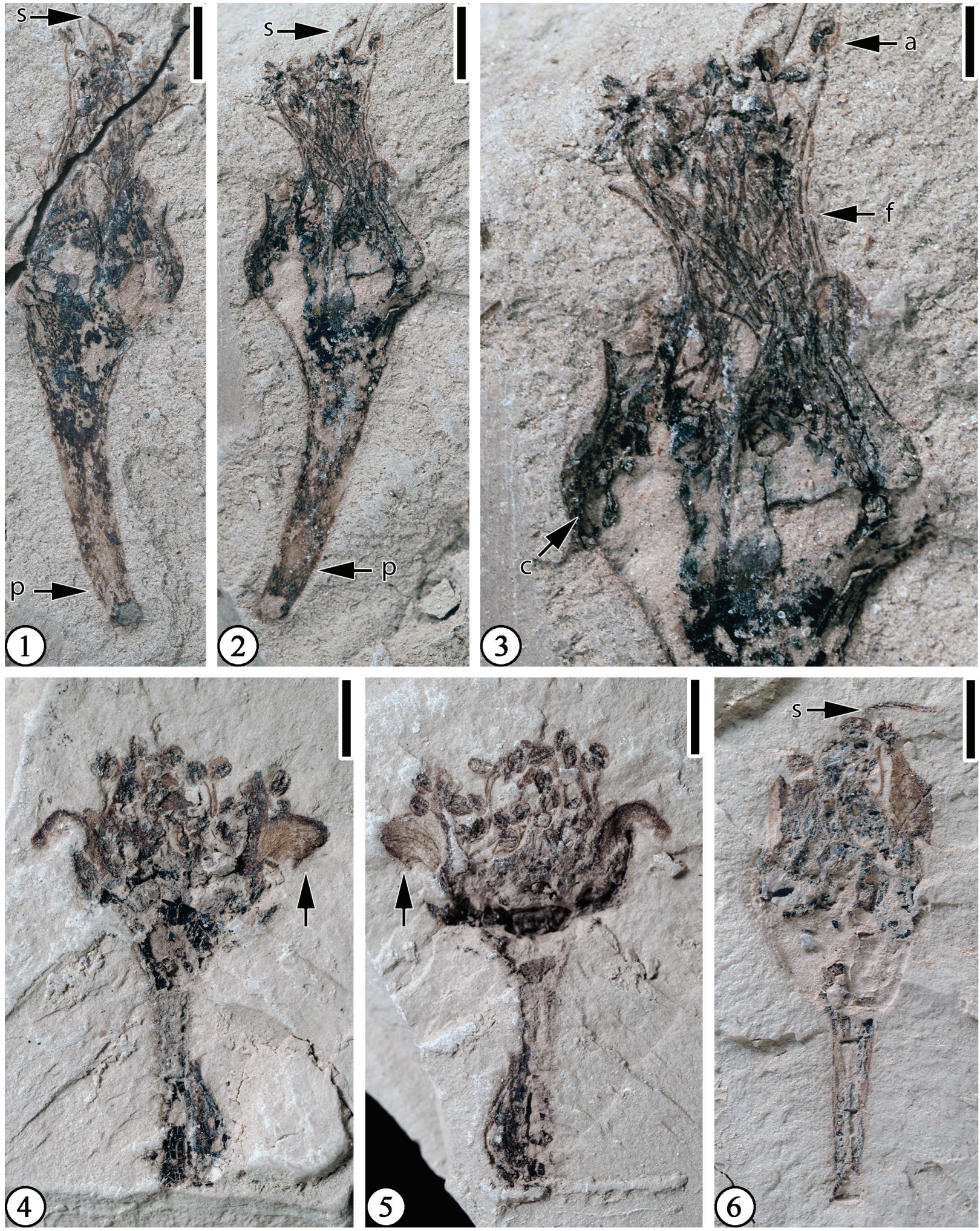

FIGURE 12. Claiborne Fabaceae Floral Type 2: 1-2) UF15738-008215, 008215'. Part and counterpart of a laterally preserved flower showing style (s) and a pedicel (p). Scale bars equal $2 \mathrm{~mm}$; 3) Enlargement of Figure 12.2 to show anthers (a), filaments (f), and calyx (c). Scale bar equals $1 \mathrm{~mm}$; 4-5) UF15737-059312, 059312'. Part and counterpart of a laterally preserved flower showing a petal (indicated by arrows) and stamens above. Scale bar equals $2 \mathrm{~mm} ; 6$ ) UF15737-059252. A laterally compressed, immature flower showing a style (s). Scale bar equals $2 \mathrm{~mm}$. 
TABLE 2. Comparison of major characters of Protomimosoidea buchananensis, Claiborne Fabaceae Floral Types 1 and 2, Claiborne Floral Types 17 and 18. All dimensions are in millimeters. "?" indicates that a measurement is not available or a character is not observed.

\begin{tabular}{|c|c|c|c|c|c|c|c|}
\hline & $\begin{array}{c}\text { Ovary size } \\
\text { (length } x \\
\text { width) }\end{array}$ & $\begin{array}{c}\text { Number } \\
\text { of } \\
\text { stamens }\end{array}$ & $\begin{array}{l}\text { Filament } \\
\text { length }\end{array}$ & $\begin{array}{l}\text { Anther size } \\
\text { (length } x \\
\text { width) }\end{array}$ & $\begin{array}{c}\text { Anther } \\
\text { connective }\end{array}$ & $\begin{array}{c}\text { Perianth } \\
\text { (length } x \\
\text { width) }\end{array}$ & $\begin{array}{l}\text { Pedicel } \\
\text { (length x } \\
\text { width) }\end{array}$ \\
\hline $\begin{array}{l}\text { Protomimosoidea } \\
\text { buchananensis }\end{array}$ & $2 \times 1$ & 10 & 5 & $0.75-1 \times 0.5$ & strong & $2 \times 1$ & up to $6 \times 0.3$ \\
\hline $\begin{array}{l}\text { Claiborne Fabaceae Floral } \\
\text { Type } 1\end{array}$ & expanded & $?$ & 9 & $1.5 \times ?$ & $?$ & $?$ & $?$ \\
\hline $\begin{array}{l}\text { Claiborne Fabaceae Floral } \\
\text { Type } 2\end{array}$ & $2 \times 2.5$ & $>10$ & 1 & $0.5 \times 0.5$ & strong & $1 \times 1$ & $5-5.5 \times 1$ \\
\hline Claiborne Floral Type 17 & $2 \times 2.5$ & $>10$ & $4-5$ & $?$ & $?$ & $4 \times 2$ & $3.5 \times 1$ \\
\hline Claiborne Floral Type 18 & $2 \times 2$ & $4-6$ & 2, fused & $0.5-1 \times 0.5$ & very strong & $?$ & $1 \times 0.5$ \\
\hline
\end{tabular}

with two styles and one fruit with three styles are observed.

\section{Claiborne Fagaceae Fruit Type 3}

(Figure 15.1-3)

Description. Fruit $10 \mathrm{~mm}$ in diameter. Nutlets at least two, $2 \mathrm{~mm}$ long and $1 \mathrm{~mm}$ wide, enclosed by three spiny cupule valves; basal portion of the spines forming a web-like pattern with lamina tissues within the network and distal portion of the spines simple or branched. Simple trichomes present on the spines and lamina tissue. Peduncle short, $0.5-1 \mathrm{~mm}$ long with scattered simple spines.

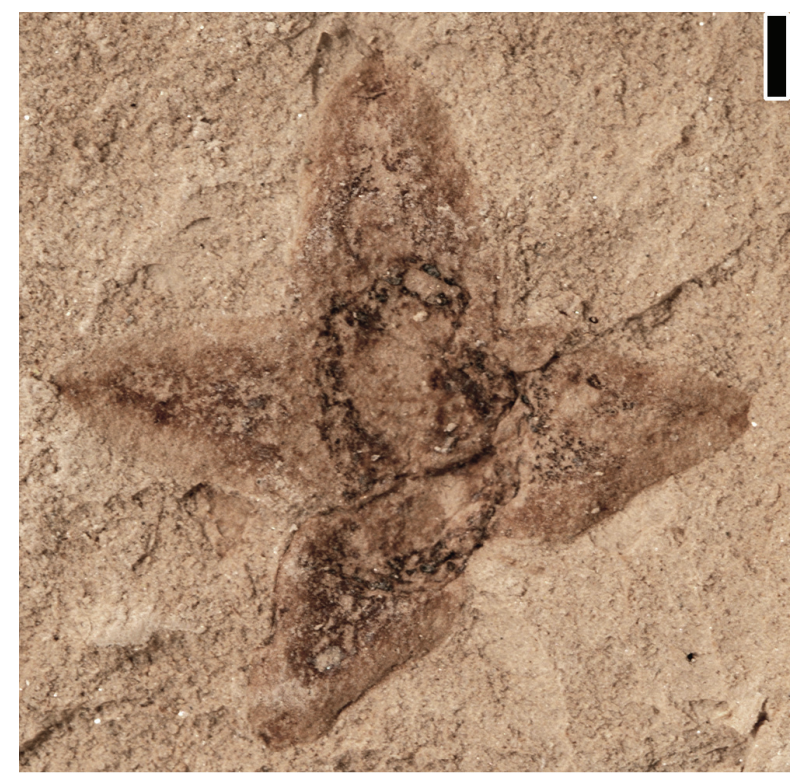

FIGURE 13. cf. Populus sp., UF15738-008213. Specimen showing a four-valved capsule. Scale bar equals 1 $\mathrm{mm}$.
Number of specimens examined. 3. UF15815005347 (Figure 15.1-2); UF15826-029215 (figure 2.F in DeVore et al., 2014); UF15826-51307 (Figure 15.3; figure 17.4 in Wang et al., 2013; figure 2C in DeVore et al., 2014).

Remarks. All the fagaceous fruit types described in this manuscript are assigned to Fagaceae based on the presence of three spiny cupule valves characteristic of extant members of the family. Here we revise the Claiborne Fagaceae Fruit Type 3 to include three specimens, one from the Lamkin clay pit, Kentucky (UF15815-005347, Figure 15.1-2), and two specimens from the Warman clay pit, Tennessee. DeVore et al. (2014, figure 2F) illustrated detail of branched spines at the margin of the involucre of one specimen from Warman (UF15826029215). The second specimen from Warman (UF15826-51307) was illustrated by Wang et al. (2013, figure 17.4) and by DeVore et al. (2014, figure $2 \mathrm{C}$ ) and is also presented here in Figure 15.3. We transfer UF15826-029216 (Figure 15.5), also illustrated by Wang et al. (2013, figure 17.1-3) to a new morphotype, Claiborne Fagaceae Fruit Type 5 (see discussion below), because of its large size. This revision increases the number of taxa/morphotypes recognized from Warman from 61 to 62 .

The fruit size and the morphology of Claiborne Fagaceae Fruit Type 3 are similar to those of Catahoulea grahamii DeVore, Pigg, Dilcher and Freile (DeVore et al., 2014; also see Figure 15.4 in this paper) from the Oligocene Huntsville locality, Texas. However, they differ in that each fruit of Claiborne Fagaceae Fruit Type 3 has a very short peduncle and three spiny cupule valves (Table 3 ). The peduncle of the specimens from the Huntsville locality is very long relative to the involucre or the 


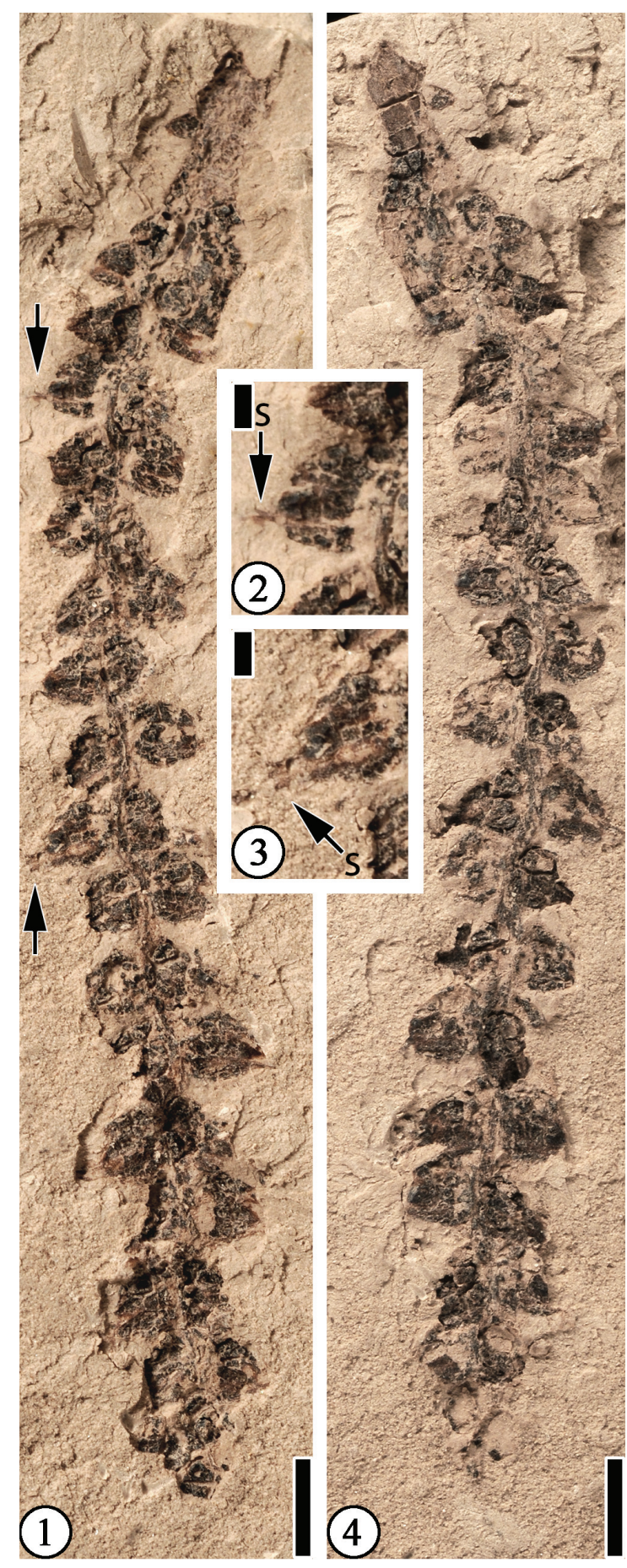

FIGURE 14. cf. Trigonobalanoidea americana Crepet and Nixon, 1989: 1) UF15737-059224. An immature infructescence with at least 32 sessile fruits. Scale bar equals $2 \mathrm{~mm}$; 2) Enlargement of a fruit indicated by the upper arrow in Figure 14.1 to show two styles (s, indicated by arrow). Scale bar equals $0.5 \mathrm{~mm}$; 3 ) Enlargement of a fruit indicated by the lower arrow in Figure 14.1 to show three styles (s, indicated by arrow). Scale bar equals 0.5 $\mathrm{mm}$; 4) Counterpart of Figure 14.1 showing an immature infructescence. Scale bar equals $2 \mathrm{~mm}$. nutlet. For example, the peduncle of the holotype specimen (DeVore et al., 2014, figure 1A; also see Figure 15.4 in this paper) is about four times as long as the nutlet and about two times as long as the involucre (spiny cupule valve or cupule). One other major difference is that the strongly cordate shape of the involucres (spiny cupule valves) of the Huntsville specimens is not as obvious on specimens from the Warman clay pit. Because of these differences and due to a limited number of specimens (one from the Lamkin locality, Kentucky and two from the Warman locality, Tennessee), we temporarily separate them as two different types. However, future collection may prove that these two fruit types belong to the same taxon. The fruits of Catahoulea grahamii may also have three spiny cupule valves. The spiny cupule valves of Claiborne Fagaceae Fruit Type 3, Claiborne Fagaceae Fruit Type 5, and C. grahamii, may not, or only slightly, enclose the nutlets.

\section{Claiborne Fagaceae Fruit Type 4 (Figure 16)}

Description. Laterally preserved fruit $1.2 \mathrm{~cm}$ long and $6.5 \mathrm{~mm}$ wide. Apex acute. Dark core of nutlets at the basal end $5 \mathrm{~mm}$ at the widest point and 7 $\mathrm{mm}$ long, surrounded by a spiny cupule; spines of the cupule branched, intertwined, or interlocking. Three ridges/grooves present, converging at both ends of the fruit body. Peduncle $2 \mathrm{~mm}$ long and 0.5 $\mathrm{mm}$ wide, with spines.

Number of specimens examined. 1. UF15737059211.

Remarks. This specimen is similar to one of the two specimens described as Fagaceous Fruit Type 3 from the Warman clay pit, Tennessee (Wang et al., 2013, p. 23, figure 17.4) in having spiny cupule valves. The spines of this fruit are branched and interlocking, usually obscuring the surface of the cupule. Based on this observation, this specimen is more closely related to Chrysolepis or Castanea than to Fagus (Nixon, 1997). In comparison with Claiborne Fagaceae Fruit Type 3 and Catahoulea grahamii, Claiborne Fagaceae Fruit Type 4 differs from them in having two large nutlets (Table 3 ).

\section{Claiborne Fagaceae Fruit Type 5}

(Figure 15.5)

Description. Fruit $2.5 \mathrm{~cm}$ in diameter. Nutlets not observed, three spiny cupule valves present; basal portions of the spines intertwined, forming a weblike pattern with laminal tissues within the network. Distal portions of the spines simple or branched. Simple trichomes present on the spines and lamina 

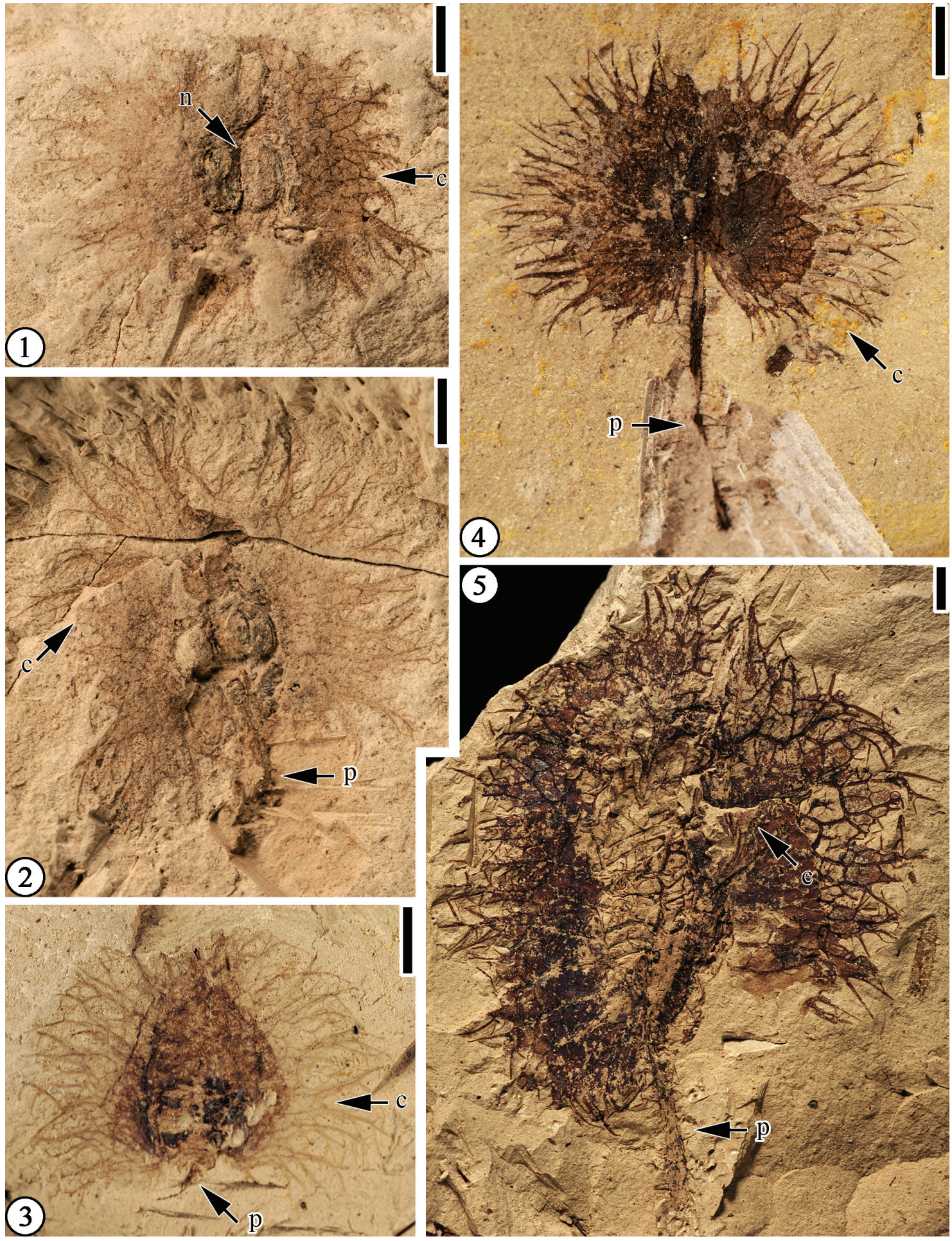

FIGURE 15. Claiborne Fagaceae Fruit Type 3 (1-3): 1) UF 15815-005347', Lamkin clay pit, Kentucky. Fruit showing two nutlets (n) and spiny cupule valve (c) with a web-like pattern. Scale bar equals $2 \mathrm{~mm}$; 2) UF 15815-005347, Lamkin clay pit, Kentucky. Counterpart of Figure 15.1 showing a short peduncle (p). Note the overlap of spiny cupule valves (c). Scale bar equals 2 mm. 3) UF 15826-051307, Warman clay pit, Tennessee. Fruit showing spiny cupule valve (c) and short peduncle (p). Scale bar equals $2 \mathrm{~mm}$. Catahoulea grahamii DeVore, Pigg, Dilcher and Freile, 2014: 4) UF 15841-062191, Huntsville, Texas. Fruit showing spiny cupule valve (c) and long peduncle (p). Scale bar equals $2 \mathrm{~mm}$. Claiborne Fagaceae Fruit Type 5 (5) UF15826-29216, Warman clay pit, Tennessee. Specimen showing peduncle $(p)$ and two overlapping spiny cupule valves (c). Scale bar equals $2 \mathrm{~mm}$. 
TABLE 3. Major characters of Claiborne Fagaceae Fruit Types 1 to 5 and Catahoulea grahamii. All dimensions are in millimeters. "?" indicates that a measurement is not available or a character is not observed.

\begin{tabular}{|c|c|c|c|c|c|c|c|c|}
\hline & $\begin{array}{c}\text { Fruit size } \\
\text { (length } x \\
\text { width) }\end{array}$ & $\begin{array}{l}\text { Number } \\
\text { of nutlets }\end{array}$ & $\begin{array}{l}\text { Nutlet size } \\
\text { (length } x \\
\text { width) }\end{array}$ & Spines & $\begin{array}{c}\text { Cupule } \\
\text { valve }\end{array}$ & $\begin{array}{l}\text { Web-like } \\
\text { pattern of } \\
\text { cupule }\end{array}$ & $\begin{array}{c}\text { Peduncle } \\
\text { (length x } \\
\text { width) }\end{array}$ & $\begin{array}{l}\text { Specimen } \\
\text { number and } \\
\text { references }\end{array}$ \\
\hline $\begin{array}{l}\text { Claiborne } \\
\text { Fagaceae } \\
\text { Fruit Type } 1\end{array}$ & $15 \times 35$ & $?$ & $?$ & $\begin{array}{l}\text { simple or } \\
\text { branched }\end{array}$ & $?$ & $?$ & $10 \times 1$ & $\begin{array}{l}\text { UF15826-51476 } \\
\text { (figure 16.1-2 in } \\
\text { Wang et al., } \\
\text { 2013) and six } \\
\text { other specimens } \\
\text { from Warman } \\
\text { clay pit, } \\
\text { Tennessee }\end{array}$ \\
\hline $\begin{array}{l}\text { Claiborne } \\
\text { Fagaceae } \\
\text { Fruit Type } 2\end{array}$ & $20 \times 20$ & $?$ & $?$ & simple & $?$ & no & $?$ & $\begin{array}{l}\text { UF15826-51231 } \\
\text { (figure } 16.3 \text { in } \\
\text { Wang et al., } \\
\text { 2013) }\end{array}$ \\
\hline $\begin{array}{l}\text { Claiborne } \\
\text { Fagaceae } \\
\text { Fruit Type } 3\end{array}$ & $10 \times 10$ & at least 2 & $2 \times 1$ & $\begin{array}{l}\text { simple or } \\
\text { branched }\end{array}$ & 3 & yes & $0.5-1 \times ?$ & $\begin{array}{l}\text { UF15815- } \\
005347 \text { (Figure } \\
\text { 15.1-2); } \\
\text { UF15826- } \\
\text { 029215 (figure } \\
\text { 2.F in DeVore et } \\
\text { al., 2014); } \\
\text { UF15826-51307 } \\
\text { (Figure 15.3; } \\
\text { figure 17.4 in } \\
\text { Wang et al., } \\
\text { 2013; figure 2.C } \\
\text { DeVore et al., } \\
\text { 2014). }\end{array}$ \\
\hline $\begin{array}{l}\text { Claiborne } \\
\text { Fagaceae } \\
\text { Fruit Type } 4\end{array}$ & $12 \times 6.5$ & at least 2 & $7 \times 5$ & branched & $?$ & $\begin{array}{c}\text { spines } \\
\text { intertwined }\end{array}$ & $2 \times 0.5$ & $\begin{array}{l}\text { UF15737-59211 } \\
\text { (Figure 16) }\end{array}$ \\
\hline $\begin{array}{l}\text { Claiborne } \\
\text { Fagaceae } \\
\text { Fruit Type } 5\end{array}$ & $\begin{array}{c}25 \text { in } \\
\text { diameter }\end{array}$ & $?$ & $?$ & branched & 3 & yes & $10 \times 1$ & $\begin{array}{l}\text { UF15826-29216 } \\
\text { (Figure 15.5; } \\
\text { figure 17.1-3 in } \\
\text { Wang et al., } \\
\text { 2013) }\end{array}$ \\
\hline $\begin{array}{l}\text { Catahoulea } \\
\text { grahamii }\end{array}$ & $5.5-10 \times 13$ & 3 & $\begin{array}{c}\text { one large, } 3 \times \\
2 ; \text { two small } 3 \\
\times 1\end{array}$ & $\begin{array}{l}\text { simple or } \\
\text { branched }\end{array}$ & 3 & yes & $9.5 \times 0.3$ & $\begin{array}{l}\text { UF } 15841 \text { - } \\
062191 \text { (Figure } \\
15.4 \text { ) and other } \\
23 \text { specimens } \\
\text { from Huntsville, } \\
\text { Texas (DeVore et } \\
\text { al., 2014) }\end{array}$ \\
\hline
\end{tabular}

tissue. Peduncle stout, $10 \mathrm{~mm}$ long, and $1 \mathrm{~mm}$ wide with scattered simple spines.

Number of specimens examined. 1. UF1582629216 (Figure 15.5).

Remarks. This specimen was included in Claiborne Fagaceous Fruit Type 3 by Wang et al. (2013, p. 26, figure 17.1-3). In this paper, we assign this specimen to a new type because of its large fruit size and its stout, relatively long pedun- cle (Table 3). Table 3 summarizes the major characters of the five Claiborne Fagaceae fruit types and those of Catahoulea grahamii.

Order ROSALES von Berchtold and Presl, 1820 Family RHAMNACEAE de Jussieu, 1789 "Solanites" pusillus Berry, 1930

(Figures 17, 18) 

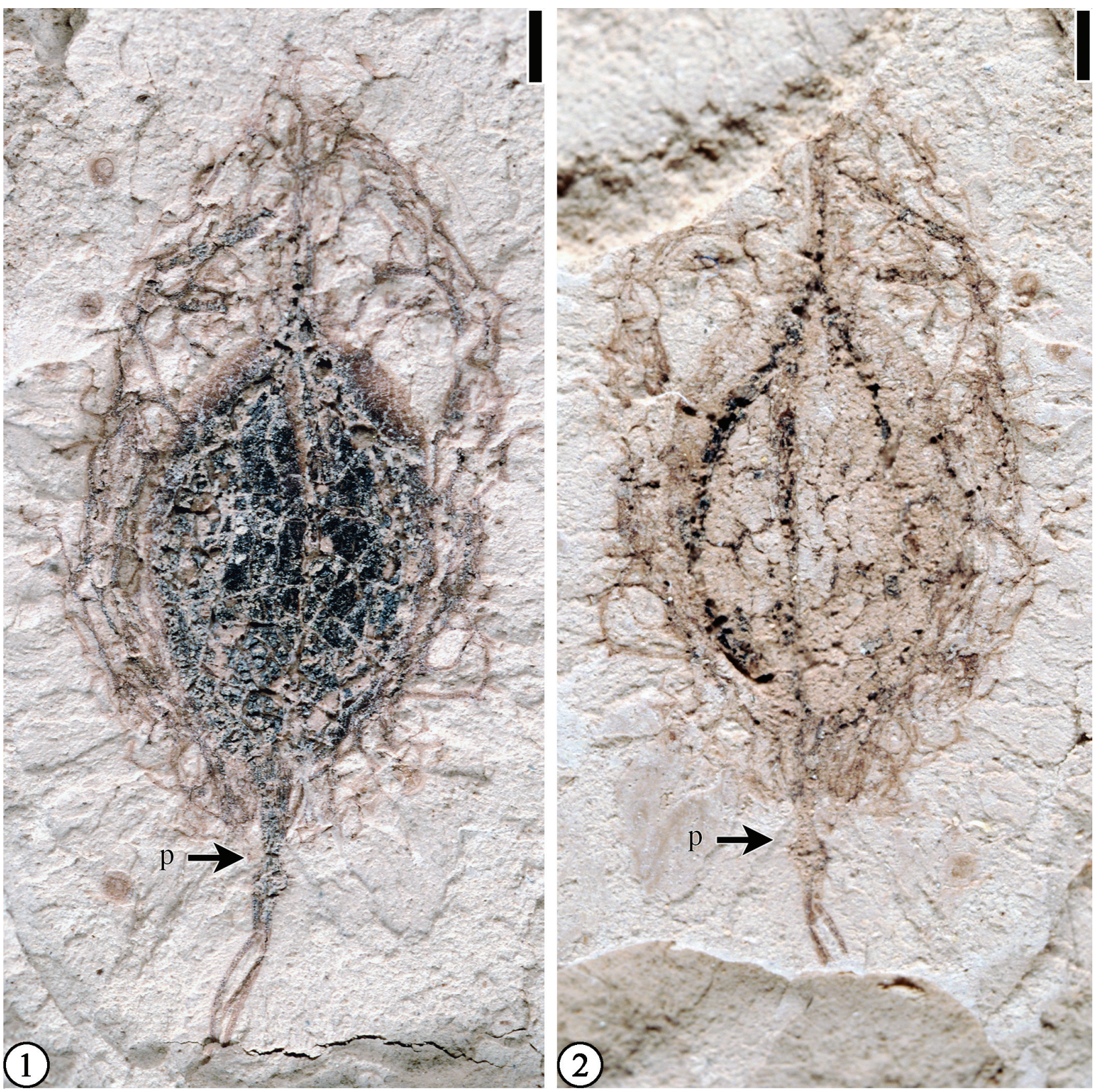

FIGURE 16. Claiborne Fagaceae Fruit Type 4: 1) UF15737-059211. Showing interwined spines, fruit body, a short peduncle ( $p)$. Scale bar equals $1 \mathrm{~mm}$; 2) UF15737-059211'. Counterpart of Figure 16.1 showing three ridges converging at both ends of the fruit body and a short peduncle $(p)$. Scale bar equals $1 \mathrm{~mm}$.

* 1930 Solanites pusillus Berry, p. 132, pl. 48, figs. 21-23.

V*2010 Solanites pusillus Berry; Martínez-Millán, p. 167-174, figs. 3.3 D-L, 3.4 A-F.

Description. Flower 5-merous, 8-10 mm in diameter; ovary inferior. Five sepals alternating with five petals; sepals equilateral or isosceles-triangular in shape, $2.5-3 \mathrm{~mm}$ long and $2.5-3 \mathrm{~mm}$ wide at the base. Petals thin, ca $3 \mathrm{~mm}$ long and $1-2 \mathrm{~mm}$ wide, often not well preserved. Sepals and petals in two separate whorls; a midvein present in each sepal, extending across the rim to the hypanthium; trichomes present on sepals, petals, and hypanthium. Well-developed hypanthium circular in vertical view (3.5-4.5 $\mathrm{mm}$ in diameter) and obtriangular in lateral view $(3.5 \mathrm{~mm}$ long and $3.5 \mathrm{~mm}$ wide at the top); a compressed distal rim ca $0.8-1 \mathrm{~mm}$ thick present. Stamens opposite the petals. Pedicel ca $1 \mathrm{~mm}$ long and $0.5 \mathrm{~mm}$ wide. 

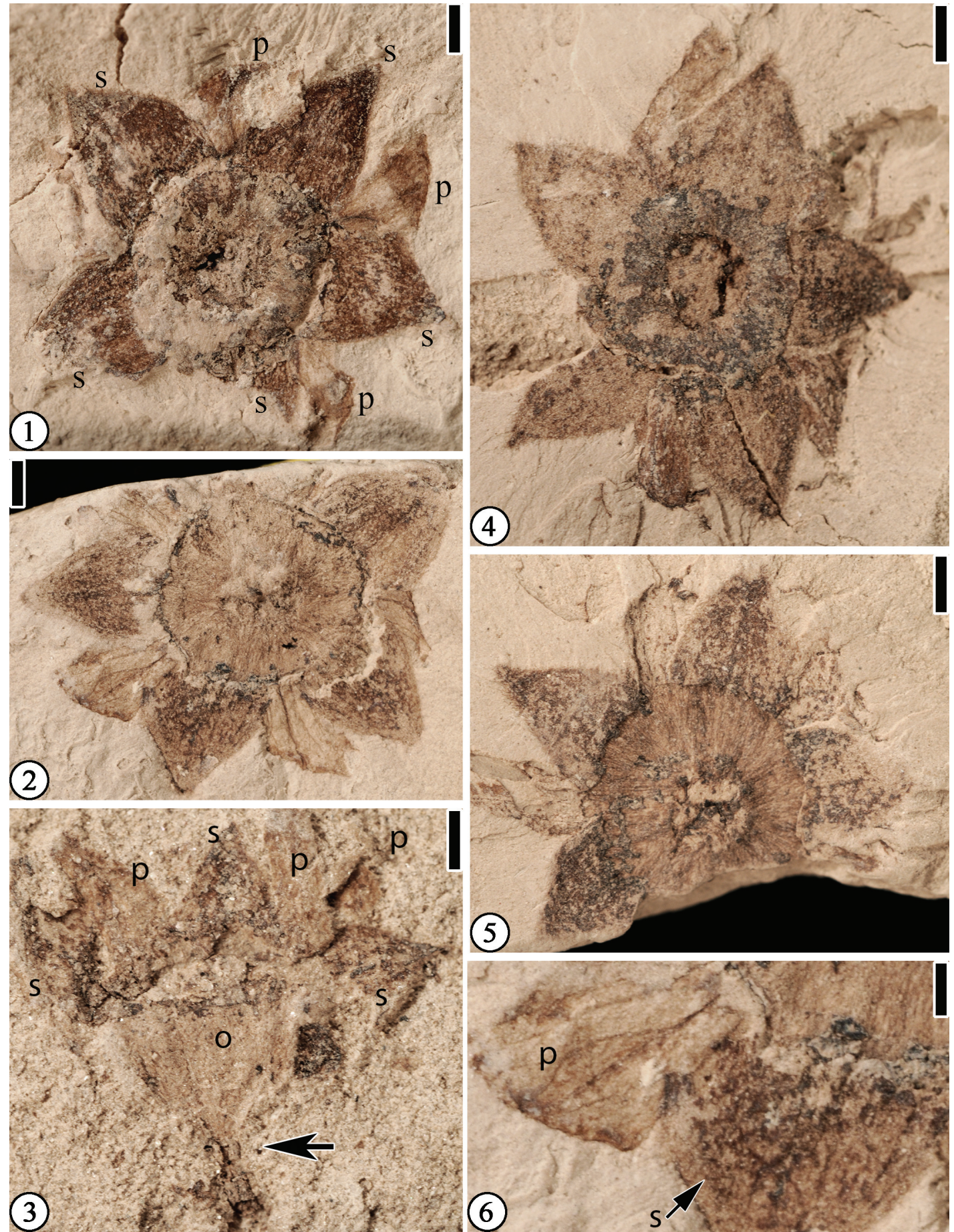

FIGURE 17. "Solanites" pusillus Berry, 1930: 1) UF15737-049568. Vertically compressed flower showing five triangular sepals (s) alternating with petals ( $\mathrm{p}$, only three are visible), and a floral cup at the center. Scale bar equals $1 \mathrm{~mm} ; 2)$ UF15737-049568'. Counterpart of Figure 17.1 showing sepals and membranaceous petals with conspicuous venation. Scale bar equals $1 \mathrm{~mm}$; 3) UF15737-008226. A laterally compressed flower showing an obtriangular hypanthium with an inferior ovary (o), a short pedicel (indicated by arrow), and three sepals (s), and three petals (p). Scale bar equals $1 \mathrm{~mm}$; 4) UF15737-049566. Vertically compressed flower showing a circular floral cup (dark concentric rings) and five triangular sepals alternating with five petals. Scale bar equals $1 \mathrm{~mm}$; 5) UF15737-049566'. Counterpart of Figure 17.4 showing sepals alternating with petals, and a floral cup with radiating veins. Note the center hole resulted from vertical compression of the pedicel. Scale bar equals $1 \mathrm{~mm} ; 6$ ) Enlargement of Figure 17.2 to show venation of sepal (s) and petal (p). Scale bar equals $0.5 \mathrm{~mm}$. 

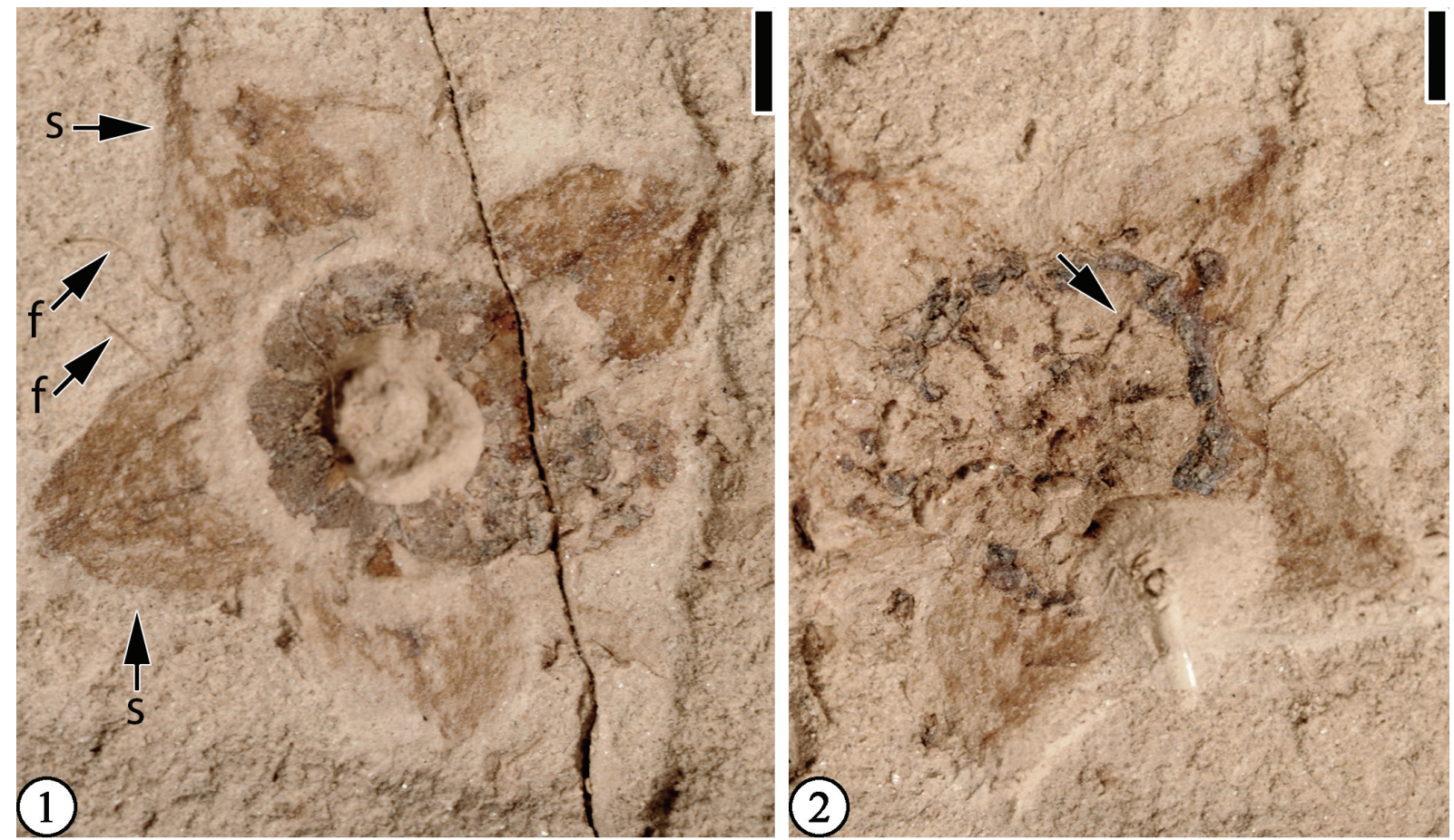

FIGURE 18. "Solanites" pusillus Berry, 1930: 1) UF15738-008214. Vertically compressed flower showing four sepals. Note two filaments (f) between two adjacent sepals (s) indicated by arrows. Scale bar equals $1 \mathrm{~mm}$; 2) UF15738008214'. Counterpart of Figure 18.1 showing five sepals and the radiating veins on the hypanthium extending to the sepals (indicated by arrow). Scale bar equals $1 \mathrm{~mm}$.

Number of specimens examined. 6. UF15737008226, 049566, 049568; UF15738-008214.

Remarks. The hypanthium is formed by the fusion of the bases of the sepals. This is indicated by the observation that the midveins of the sepals extend across the hypanthium rim nearly to the center of the floral cup in vertically preserved flowers (Figure 18.2). That the stamens are opposite the petals is indicated by the fact that two filaments are located between two sepals (Figure 18.2). See Table 4 for a comparison of Solanites pusillus with other similar Claiborne floral types.

Martínez-Millán (2010) and Millan and Crepet (2014) observed that the combination of characters including: 5-merous flowers with a cupulate hypanthium ending in a thick floral rim; triangular sepals with a prominent midvein or keel; thin, clawed cupulate petals alternating with the sepals; and stamens opposite the petals is found in the Rhamnaceae, rather than Solanaceae as suggested by Berry (1916b, 1930). They also noted that tricolporate pollen with a rugulate to striate-rugulate exine (pollen extracted from UF15737-049566; Figure 17.4 ) is also consistent with pollen of the Rhamnaceae.
Order SAPINDALES de Jussieu ex von Berchtold and Presl, 1820

Family SAPINDACEAE de Jussieu, 1789

Genus BRIDGESIA Bertero ex Cambessèdes, 1834

Bridgesia bovayensis Manchester and O'Leary, 2010

(Figure 19)

Description. "Fruit widely elliptical, 15-16 mm high, $30 \mathrm{~mm}$ wide (nearly twice as wide as high), schizocarpic, falling into at least two singly winged mericarps. Locular area, comprising $1 / 2$ to $2 / 3$ the width of the fruit, inflated; the remaining distal portion forms the wings. Each locule contains a single globose seed attached centrally to the median axis of the fruit. The pedicel is stout, articulated with the base of the fruit with a widened scar of perianth and/or disk; a very short stipe is evident between the perianth scar and the remainder of the fruit. Venation consists of main veins spreading into the wings, with frequent dichotomies and anastomoses, craspedodromous to a fimbrial vein." (Manchester and O'Leary, 2010, p. 74-76)

Number of specimens examined. 2. UF15737030660, 030661. 
TABLE 4. Comparison of characters of Claiborne Floral Type 5, Claiborne Floral Types 8 to 11, "Diospyros" mirafloriana, Eoglandulosa warmanensis, "Solanites" pusillus, "Solanites" saportanus, and "Solanites" sarachaformis. All dimensions are in millimeters. "?" indicates that a measurement is not available or a character is not observed.

\begin{tabular}{|c|c|c|c|c|c|c|c|c|c|c|}
\hline Taxa/morphotypes & 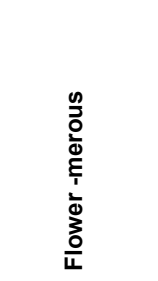 & 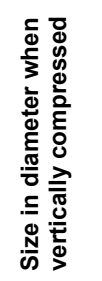 & 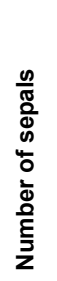 & $\begin{array}{l}\frac{\Phi}{0} \\
\frac{\pi}{0} \\
\frac{0}{\pi} \\
\frac{0}{0} \\
\infty\end{array}$ & $\begin{array}{l}\frac{0}{\pi} \\
\frac{0}{5} \\
\frac{\pi}{\pi} \\
\frac{0}{0} \\
\text { ஸे }\end{array}$ & 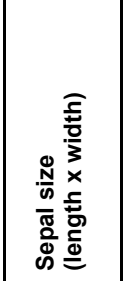 & 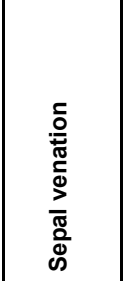 & 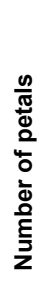 & $\begin{array}{l}\frac{0}{0} \\
\frac{0}{0} \\
\frac{5}{00} \\
\frac{\pi}{0} \\
0\end{array}$ & 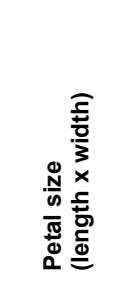 \\
\hline $\begin{array}{l}\text { Claiborne Floral } \\
\text { Type } 5\end{array}$ & 5- merous & 22 & $?$ & $?$ & $?$ & $?$ & $?$ & $?$ & $?$ & $?$ \\
\hline $\begin{array}{l}\text { Claiborne Floral } \\
\text { Type } 8\end{array}$ & ?4- merous & 8 & $?$ & $?$ & $?$ & $?$ & $?$ & $?$ & $?$ & $?$ \\
\hline $\begin{array}{l}\text { Claiborne Floral } \\
\text { Type } 9\end{array}$ & 5- merous & 6 & $?$ & $?$ & $?$ & $?$ & $?$ & $?$ & $?$ & $?$ \\
\hline $\begin{array}{l}\text { Claiborne Floral } \\
\text { Type } 10\end{array}$ & 6- merous & 15 & $?$ & $?$ & $?$ & $?$ & $?$ & 6 & ovate & $5 \times 2-2.5$ \\
\hline $\begin{array}{l}\text { Claiborne Floral } \\
\text { Type } 11\end{array}$ & ?4- merous & 11 & $?$ & $?$ & $?$ & $?$ & $?$ & $?$ & $?$ & $?$ \\
\hline $\begin{array}{l}\text { "Diospyros" } \\
\text { mirafloriana }\end{array}$ & 5- merous & $35-40$ & 5 & separate & $?$ & $\begin{array}{c}12.5 \mathrm{x} \\
9.5\end{array}$ & $?$ & $?$ & $?$ & $?$ \\
\hline $\begin{array}{l}\text { Eoglandulosa } \\
\text { warmanensis } \\
\text { (Wang et al. } \\
\text { 2013) }\end{array}$ & 5- merous & 10 & $? 5$ & connate & $\begin{array}{l}\text { oblong to } \\
\text { triangular }\end{array}$ & $4 \times 2$ & $?$ & $?$ & $?$ & $?$ \\
\hline $\begin{array}{l}\text { "Solanites" } \\
\text { pusillus }\end{array}$ & 5- merous & $8-10$ & 5 & separate & $\begin{array}{l}\text { isosceles- } \\
\text { triangular }\end{array}$ & \begin{tabular}{|c|}
$2.5-3 x$ \\
$2.5-3$
\end{tabular} & $\begin{array}{c}\text { mid-vein } \\
\text { present }\end{array}$ & 5 & $?$ & $3 \times 1-2$ \\
\hline $\begin{array}{l}\text { "Solanites" } \\
\text { saportanus }\end{array}$ & 6- merous & 9 & 6 & separate & triangular & $3 \times 2$ & $\begin{array}{c}\text { mid-vein } \\
\text { present }\end{array}$ & $?$ & $?$ & $?$ \\
\hline $\begin{array}{l}\text { "Solanites" } \\
\text { sarachaformis }\end{array}$ & 4- merous & 10 & 4 & separate & ovate & $4.5 \times 3.5$ & 5 veins & $?$ & $?$ & $?$ \\
\hline
\end{tabular}

Remarks. These are the two specimens that were described by Manchester and O'Leary (2010, p. 74-76, figure $24 \mathrm{k}-\mathrm{m})$. They suggested that morphological characters of these fossil fruits, including wing venation and seed shape, are best matched by the extant genus Bridgesia. This assignment of the fossils to this genus has significant biogeographic implications, because extant Bridgesia is known only from Chile, South America.

Order ERICALES Dumortier, 1829

Family THEACEAE Mirbel ex Ker Gawler, 1816

Genus GORDONIA Ellis, 1771

Gordonia warmanensis Grote and Dilcher, 1992

(Figure 20)

v*2013 Gordonia warmanensis Grote and Dilcher; Wang et al., p. 30, fig. 24.
Description. Winged seed $1.5 \mathrm{~cm}$ long and $4 \mathrm{~mm}$ wide at the widest part of the wing at the point of attachment to the seed. Ventral margin of wing slightly concave; dorsal margin convex; apex of wing rounded. Seed triangular, $6 \mathrm{~mm}$ long, and 4 $\mathrm{mm}$ at widest point.

Number of specimens examined. 3. UF15737059235, 059239.

Remarks. Four dispersed seeds have been reported from the Warman clay pit (Grote and Dilcher, 1992; Wang et al., 2013). These seeds were assigned to the same species as the capsules found at the Warman clay pit because of their similarity to the in situ seed fragment in having an oblique body with a concave ventrobasal border and a rounded basal tip (Grote and Dilcher, 1992). 
TABLE 4 (continued).

\begin{tabular}{|c|c|c|c|c|c|c|c|c|c|c|c|}
\hline Taxa/morphotypes & 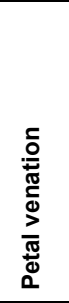 & 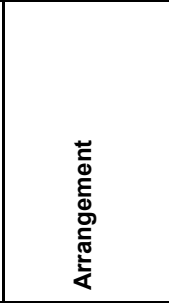 & 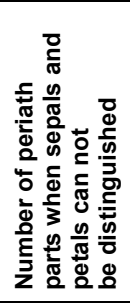 & $\begin{array}{l}\frac{0}{\pi} \\
\frac{0}{0} \\
\frac{5}{9} \\
\frac{1}{\pi} \\
\frac{0}{2} \\
\frac{5}{0} \\
\frac{1}{5} \\
\frac{\pi}{0} \\
0\end{array}$ & 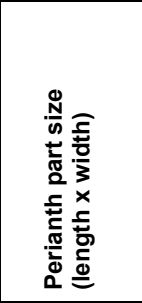 & 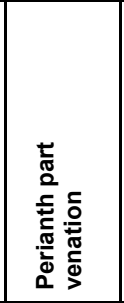 & 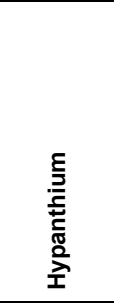 & 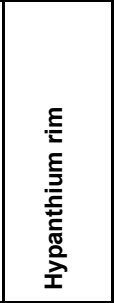 & 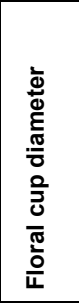 & $\begin{array}{l}\frac{\pi}{0} \\
\text { o } \\
\text { O }\end{array}$ & 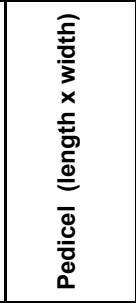 \\
\hline $\begin{array}{l}\text { Claiborne Floral } \\
\text { Type } 5\end{array}$ & $?$ & $?$ & 5 & ovate & $7 \times 5$ & $\begin{array}{l}\text { faint } \\
\text { veins }\end{array}$ & present & $?$ & $?$ & superior & $?$ \\
\hline $\begin{array}{l}\text { Claiborne Floral } \\
\text { Type } 8\end{array}$ & $?$ & $\begin{array}{c}\text { alternate, } 2 \\
\text { whorls }\end{array}$ & 8 & $\begin{array}{c}\text { triangula } \\
r\end{array}$ & $\begin{array}{c}1.5-2.5 x \\
1.5-2\end{array}$ & 5 veins & present & present & 3 & superior & $? \times 0.5$ \\
\hline $\begin{array}{l}\text { Claiborne Floral } \\
\text { Type } 9\end{array}$ & $?$ & $?$ & 5 & $\begin{array}{c}\text { triangula } \\
\mathrm{r}\end{array}$ & $2 \times 1$ & $\begin{array}{c}\text { not } \\
\text { observed }\end{array}$ & present & present & $?$ & $2-3$ & $? \times 0.2$ \\
\hline $\begin{array}{l}\text { Claiborne Floral } \\
\text { Type } 10\end{array}$ & thin & $?$ & $?$ & $?$ & $?$ & $?$ & $?$ & $?$ & $?$ & inferior & $?$ \\
\hline $\begin{array}{l}\text { Claiborne Floral } \\
\text { Type } 11\end{array}$ & $?$ & $?$ & $?$ & ovate & $5 \times 3$ & $\begin{array}{l}\text { fine } \\
\text { veins }\end{array}$ & $?$ & $?$ & $?$ & $?$ & $\begin{array}{c}\text { long; } 10 \mathrm{x} \\
0.5\end{array}$ \\
\hline $\begin{array}{l}\text { "Diospyros" } \\
\text { mirafloriana }\end{array}$ & $?$ & $?$ & $?$ & $?$ & $?$ & $?$ & present & present & 12.5 & $?$ & $?$ \\
\hline $\begin{array}{l}\text { Eoglandulosa } \\
\text { warmanensis } \\
\text { (Wang et al. } \\
\text { 2013) }\end{array}$ & $?$ & $?$ & $?$ & $?$ & $?$ & $?$ & $?$ & $?$ & $?$ & $?$ & $?$ \\
\hline $\begin{array}{l}\text { "Solanites" } \\
\text { pusillus }\end{array}$ & $?$ & $\begin{array}{c}\text { alternate, two } \\
\text { whorls }\end{array}$ & $?$ & $?$ & $?$ & $?$ & present & present & $\begin{array}{c}3.5- \\
4.5\end{array}$ & inferior & $1 \times 0.5$ \\
\hline $\begin{array}{l}\text { "Solanites" } \\
\text { saportanus }\end{array}$ & $?$ & $?$ & $?$ & $?$ & $?$ & $?$ & present & absent & 4 & $?$ & $? \times 0.5$ \\
\hline $\begin{array}{l}\text { "Solanites" } \\
\text { sarachaformis }\end{array}$ & $?$ & $?$ & $?$ & $?$ & $?$ & $?$ & present & absent & $?$ & $?$ & $?$ \\
\hline
\end{tabular}

The oblique arrangement of the seed body is also a diagnostic character distinguishing these specimens from other winged fossil seeds, including Saportaspermum occidentalis (Meyer and Manchester, 1997, pl. 74, figures 14-20) and Saportaspermum kovacsiae (Kvaček and Wilde, 2010, p.172-178, figure 9A-H; Collinson et al., 2010, figure 1F; Collinson et al., 2012, plate 46a-h).

Order ICACINALES van Tieghem, 1900

Family ICACINACEAE Miers, 1851

Genus NATSIATUM Buchanan-Hamilton ex Arnott, 1834

Natsiatum wilcoxiana (Berry) Stull, Moore and Manchester, 2011

cf. Natsiatum wilcoxiana (Berry) Stull, Moore and Manchester, 2011

(Figure 21)
Description. Fragment of an endocarp, ca. $6 \mathrm{~mm}$ long, and $3 \mathrm{~mm}$ wide, with irregular, blindly ending ridges.

Number of specimens examined. 1. UF15737059325.

Remarks. The specimen consists of only a fragment and it cannot be confidently assigned to any of the species described by Stull et al. (2011). They reported three species in three different genera of the Icacinaceae from the Claiborne Group of Tennessee and Mississippi. The blindly ending ridges of the Bovay specimen are suggestive of its possible relationship with the genus Natsiatum.

Order GARRYALES von Martius, 1835

Family EUCOMMIACEAE Engler, 1907 Genus EUCOMMIA Oliver, 1890 

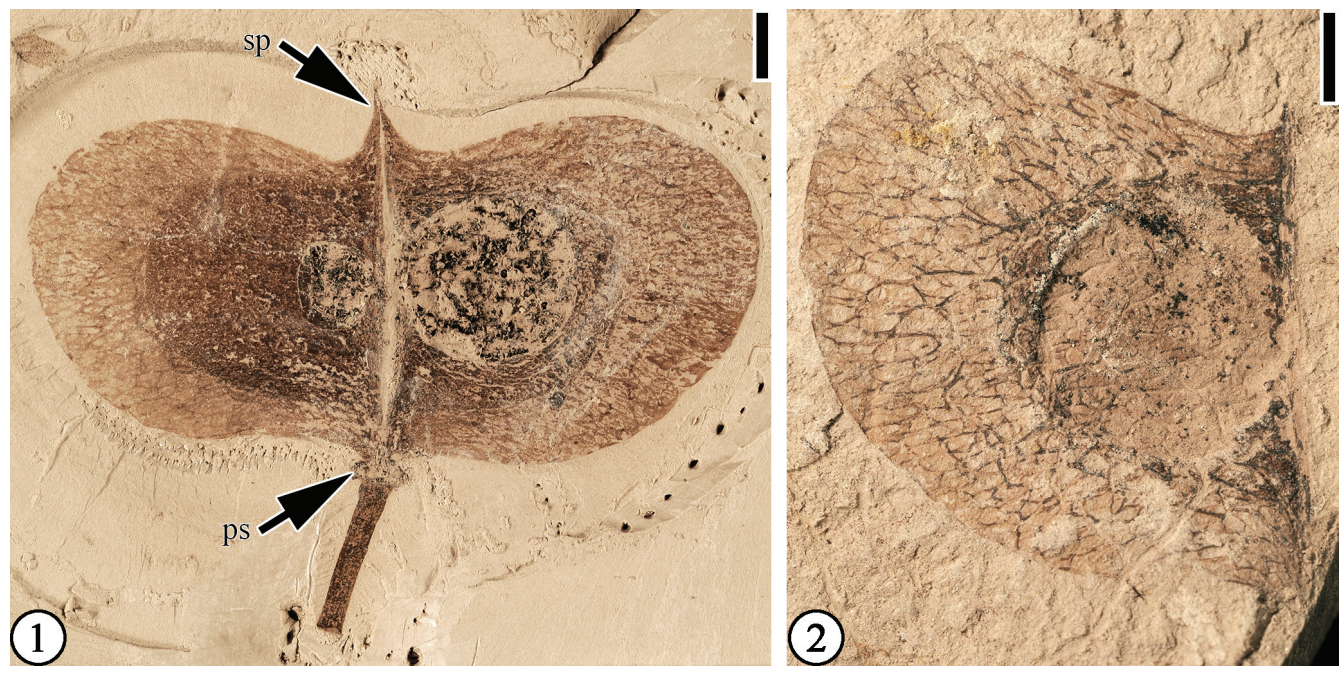

FIGURE 19. Bridgesia bovayensis Manchester and O'Leary, 2010: 1) UF15737-30660. Fruit showing pedicel, hypogynous perianth scar (ps), stylar protrusion (sp), and two mericarps each with a large darkened locular area. Scale bar equals $3 \mathrm{~mm}$; 2) UF15737-30661. Mericarp showing reticulate veins on the wing and locular area. Scale bar equals 3 $\mathrm{mm}$.

\section{Eucommia eocenica (Berry) Brown, 1940}

(Figure 22)

v. 1930 Carpolithus banisteroides Berry, p. 134; pl. 33, figs. 5-6.

v. 1930 Simarubites eocenicus Berry, p. 94; pl. 44, figs. 15-16.

v. 1940 Eucommia eocenica (Berry) Brown; Brown, p. 349.

v*1997 Eucommia eocenica (Berry) Brown; Call and Dilcher, p. 800, figs. 4-12, 16-17.

v*1999 Eucommia eocenica (Berry) Brown; Manchester, p. 480, fig. 3B.

Description. "Fruits are asymmetrical, stipitate, bicarpellate samaras composed of a flattened ovate nutlet surrounded by an ovate narrow wing. The fruit apex is more or less acute. Samara length (excluding stipe) ranges from 11.5 to $21 \mathrm{~mm}$ (average $15.1, \mathrm{~N}=13$ ), and samara width varies from 4.5 to $8.2 \mathrm{~mm}$ (average 6.33, $\mathrm{N}=13$ ). The ratio of samara length to samara width varies from about 2 to 3 (average 2.4). Stipe length ranges from 2.5 to $5.0 \mathrm{~mm}$. Stipe width at the base of the fruit body is approximately $1.0 \mathrm{~mm}$, tapering slightly and evenly basipetally. The stipe is attached at an angle of $45^{\circ \prime \prime}$ (Call and Dilcher, 1997, p. 801).

Number of specimens examined. 18. UF157378218, 8219, 11022, 11032, 11033, 11035, 11063, 11065, 11066; UF15738-11027, 11028, 11030a, 11030 'a, 52526.

Remarks. Extant Eucommia is a monotypic genus of deciduous trees native to central China (Zhang et al., 2003). However, fossil records show a much wider distribution in the Eocene of the western and southeastern United States (Call and Dilcher, 1997; Geng et al., 1999; Manchester, 1999, 2000, 2001; Manchester et al., 2009), northeast China (Geng et al., 1999), and Japan (Huzioka, 1961), the Oligocene or Miocene of southern Mexico (MagallónPuebla and Cevallos-Ferriz, 1994), the lower Oligocene of Kazakhstan (Akhmetiev, 1991) and Russia (Ablaev et al., 1993), the Miocene of east China (Hu and Chaney, 1940; Wang et al., 2003), Oligocene to upper Pliocene of Europe (Szafer, 1950, 1954; Tralau, 1963; Negru, 1972; Zhilin, 1989; Mai, 1995), and the Miocene to Pliocene of Japan (Tanai, 1961).

Many fossil fruits (Call and Dilcher, 1997; Manchester, 1999; Manchester et al., 2009) have been reported from the Bovay and Bolden clay pits and other localities (personal observation). However, only one fragmentary leaf, i.e., Eucommia rolandii Call and Dilcher (1997, p. 808-809, figures $13,14,18,19)$, has been reported from the Bovay locality.

Call and Dilcher (1997, figure 9) indicated that one fruit (UF15738-011030) possesses two mature carpels. Our examination of both part and counterpart of this specimen (Figure 22.12-13) shows that they are two fruits compressed together at their apices. If, as interpreted by Call and Dilcher (1997), the two nearly equally developed carpels form a bilaterally symmetrical samara whose apical stigmatic cleft, ventral suture, and stipe lie along the median longitudinal plane of the samara, it would be difficult to explain the gap between the 

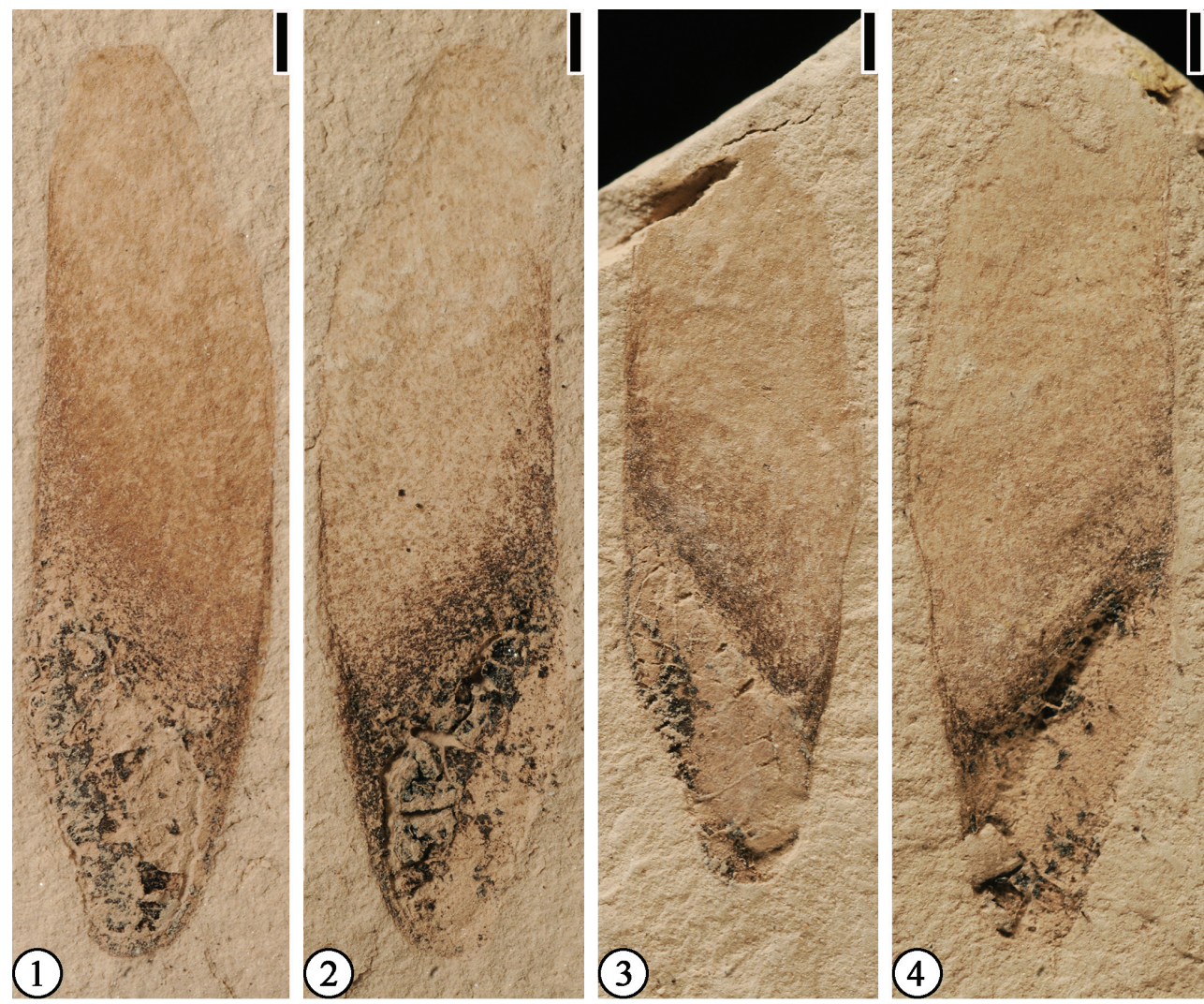

FIGURE 20. Gordonia warmanensis Grote and Dilcher, 1992: 1-2) UF 15737-059235, 059235'. Part and counterpart of a specimen showing a winged seed. Note slightly concave ventral margin and convex dorsal margin. Scale bar equals $1 \mathrm{~mm}$; 3-4) UF 15737-059239, 059239 '. Part and counterpart of a specimen showing slightly concave ventral margin and convex dorsal margin. Scale bar equals $1 \mathrm{~mm}$.

two carpels at the base and why only one carpel bears the stipe.

\section{Order DIPSACALES de Jussieu ex von Berchtold} and Presl, 1820

Family CAPRIFOLIACEAE de Jussieu, 1789

Genus DIPELTA Maximowicz, 1877

Dipelta bovayensis sp. nov.

(Figure 23)

v. 2009 Dipelta sp., Manchester et al., 2009, p. 18, fig. 14.

Diagnosis. Fruit with two accrescent, membranous, wing-like bracts. Bract very wide ovate, margin entire, base auriculate, apex obtuse, with length/width ratio 1 . Primary veins actinodromous, slightly converging toward the apex; medial primary vein extending directly toward the apex; lateral primary veins and branches from medial primary vein dichotomizing and joining adjacent branches to form reticulate meshes that become successively smaller toward the margin. Pedicel thin.

Description. Fruit with two accrescent, membranous, wing-like bracts, overlapping when com-
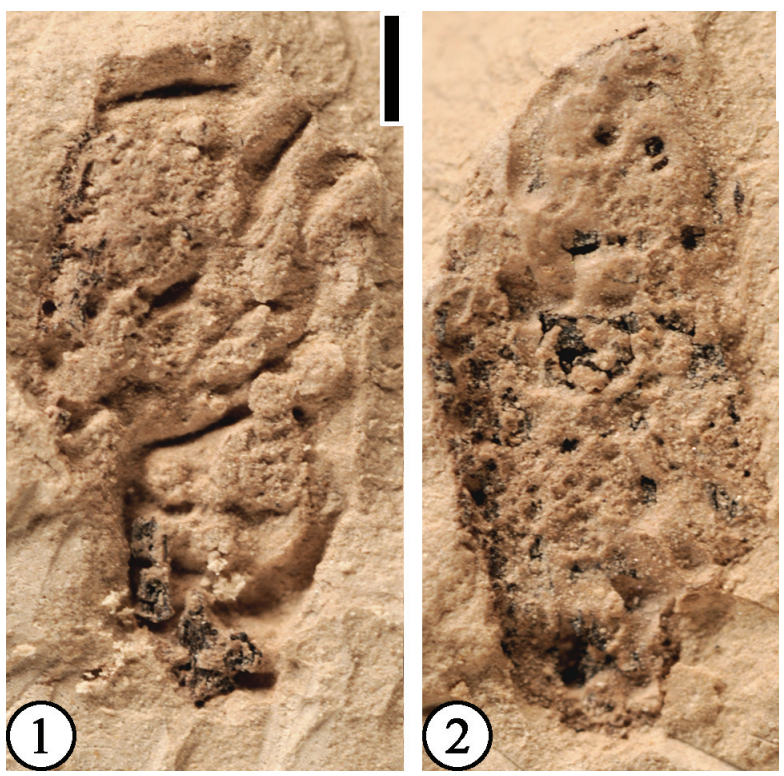

FIGURE 21. cf. Natsiatum wilcoxiana (Berry) Stull et al., 2011: 1-2) UF15737-059325, 059325'. Part and counterpart of a specimen showing irregular, blindly ending ridges. Scale bar equals $1 \mathrm{~mm}$. 

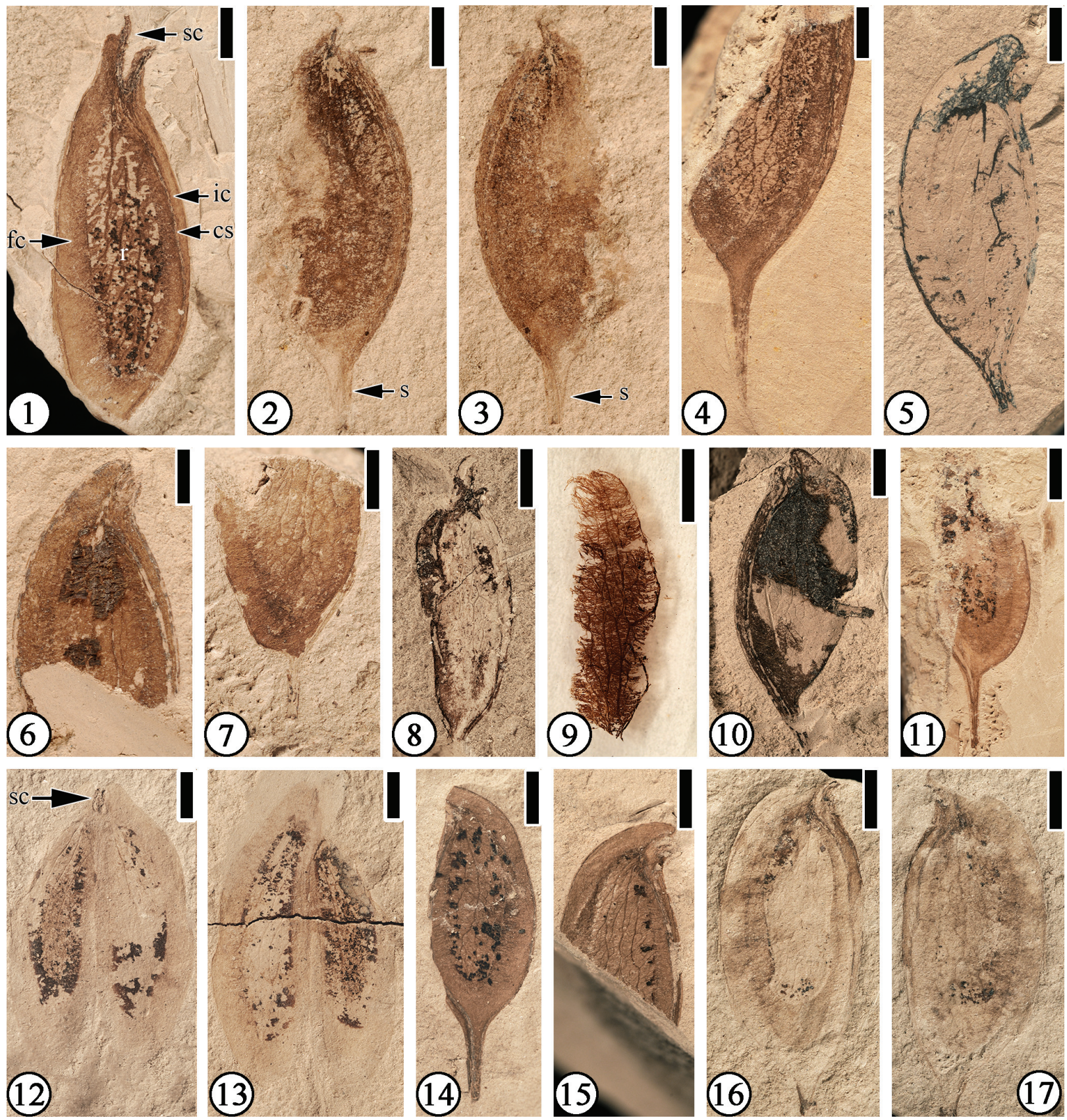

FIGURE 22. Eucommia eocenica (Berry) Brown, 1940: 1) UF 15737-008218. Fruit showing apical stigmatic cleft (sc), fertile carpel (fc) bearing a conspicuous reticulum ( $r$ ) composed of fascicles of vascular strands, infertile carpel (ic), and carpel suture (cs). Scale bar equals $2 \mathrm{~mm}$; 2, 3) UF 15737-011033, 011033'. Part and counterpart of a specimen showing stout stipe (s). Scale bar equals $3 \mathrm{~mm}$; 4) UF 15737-011032 - Incomplete fruit showing longer stipe. Scale bar equals $2 \mathrm{~mm}$; 5) UF 15737-011063. Well developed fruit showing vascular strands of the reticulum and stout stipe. Scale bar equals $2 \mathrm{~mm}$; 6) UF 15737-011035. Distal half of fruit showing compression of latex strands and strong carpel suture. Scale bar equals $2 \mathrm{~mm}$; 7) UF15738-011027. Fruit showing stout stipe. Scale bar equals $3 \mathrm{~mm}$; 8-9) UF15737-011022, 011022'. Fruit showing impression of reticulum, and compression of vascular and latex strands. Scale bar equals $3 \mathrm{~mm}$; 10) UF 15737-008219. Fruit showing well developed fertile carpel on the right and infertile carpel on the left. Scale bar equals $3 \mathrm{~mm}$; 11) UF 15737-011065. Fruit showing a complete stipe. Scale bar equals $3 \mathrm{~mm}$. 12-13) UF 15738-011030a, 011030'a. Part and counterpart of a specimen showing two fruits. Note stigmatic cleft (sc). Scale bar equals $3 \mathrm{~mm}$; 14-15) UF 15738-0052526, 0252526'. Part and counterpart of a specimen showing stigmatic cleft, reticulum, and stipe. Scale bar equals $3 \mathrm{~mm}$; 16-17) UF15738-011028, 011028'. Fruit showing short stipe. Scale bar equals $3 \mathrm{~mm}$. 

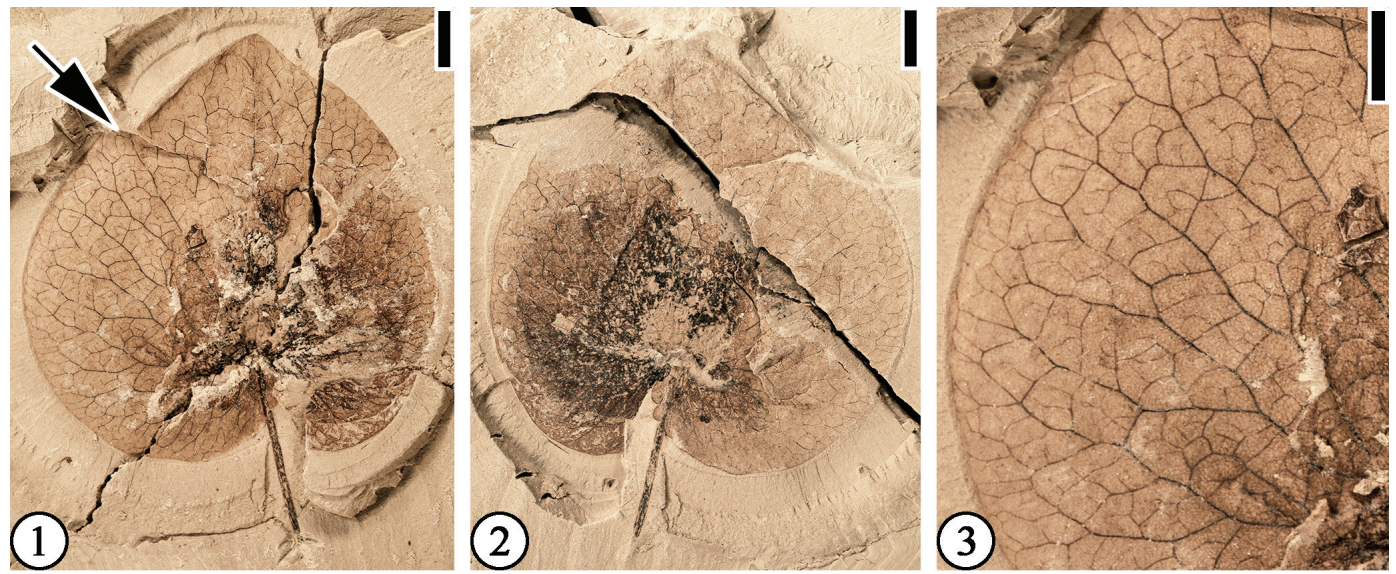

FIGURE 23. Dipelta bovayensis sp. nov.: 1-2) UF15737-049026, 049026'. Part and counterpart of a specimen showing a fruit with two overlapping bracts (indicated by arrow), venation, and a slender pedicel. Note obtuse apex of the top bract. Scale bar equals $3 \mathrm{~mm}$; 3) Enlargement of Figure 23.1 to show reticulate venation. Scale bar equals $3 \mathrm{~mm}$.

pressed. Bract very wide ovate, margin entire, base auriculate, apex obtuse, $1.8 \mathrm{~cm}$ long and 1.8 $\mathrm{cm}$ wide (length/width ratio 1 ). Five primary veins present, actinodromous, slightly converging toward the apex; medial primary vein extending directly toward the apex; lateral primary veins and branches from medial primary vein dichotomizing and joining adjacent branches to form reticulate meshes that become successively smaller toward the margin. Pedicel thin, $10 \mathrm{~mm}$ long, and $0.5 \mathrm{~mm}$ wide.

Number of specimens examined. 1. Holotype (designated here): UF15737-049026.

Occurrence. Bovay clay pit, Mississippi.

Age and horizon. Late early Eocene, Tallahatta Formation.

Remarks. The fruit (achene) and the persistent calyx are not observed. Manchester et al. (2009, p. 18, figure 14) assigned this specimen to extant Dipelta based on shared characteristic arrangement and venation of the bracts, and the presence of a narrow, persistent pedicel. Modern Dipelta are deciduous shrubs in mixed or broad-leaved forests (600-2400 m elevation) in Gansu, Guangxi, Guizhou, Hubei, Hunan, Shaanxi, Sichuan, and Yunnan Provinces of China (Yang and Landrein, 2011). The enlarged bracts function in wind dispersal (Manchester et al., 2009, figure 12). Fossils also have been reported from the early Oligocene of England (Reid and Chandler, 1926; also see figure 13 in Manchester et al., 2009). This specimen from the lower Eocene Tallahatta Formation of Mississippi, USA, represents the earliest record of this genus.
Order APIALES Nakai, 1930

Family ARALIACEAE de Jussieu, 1789

Genus PALEOPANAX Manchester, 1994

Type species. Paleopanax oregonensis Manchester, 1994, here designated.

\section{Paleopanax boldensis sp. nov.}

(Figure 24)

Diagnosis. Fruit capsule small, globose, dehiscent, with three persistent styles, an epigynous disc, and a long pedicel; carpel D-shaped.

Description. Infructescence with one middle acrocidal capsule flanked by two lateral capsules. Middle fruit small, globose, dehiscent, ca $4 \mathrm{~mm}$ in diameter; pedicel $2 \mathrm{~mm}$ long and $1 \mathrm{~mm}$ wide. Two lateral fruits also globose, 3.5 and $4 \mathrm{~mm}$ in diameter respectively; three styles, each ca $0.8 \mathrm{~mm}$ long and $0.2 \mathrm{~mm}$ wide; pedicels $5 \mathrm{~mm}$ long and $1 \mathrm{~mm}$ wide. Peduncle $16 \mathrm{~mm}$ long and $1 \mathrm{~mm}$ wide.

Number of specimens examined. 1. UF15738059493 (holotype, designated here).

Occurrence. Bolden clay pit, Mississippi.

Age and Horizon. Early Eocene, Tallahatta Formation, Claiborne Group.

Etymology. The species name refers to its occurrence at the Bolden locality, Mississippi.

Remarks. The diagnostic characters of the new species are consistent with those of the fruits from the middle Eocene Nut Beds Flora, Clarno Formation, Oregon (Manchester, 1994, p. 38-39, pl. 7, figures 3-4). Petrified wood with possible affinity to Araliaceae was also reported by Wheeler and Manchester (2014) from the Clarno Formation. It differs from the specimens from the Nut Beds in not having an obvious epigynous disc. Leaves belonging to the family Araliaceae, i.e., Dendropa- 


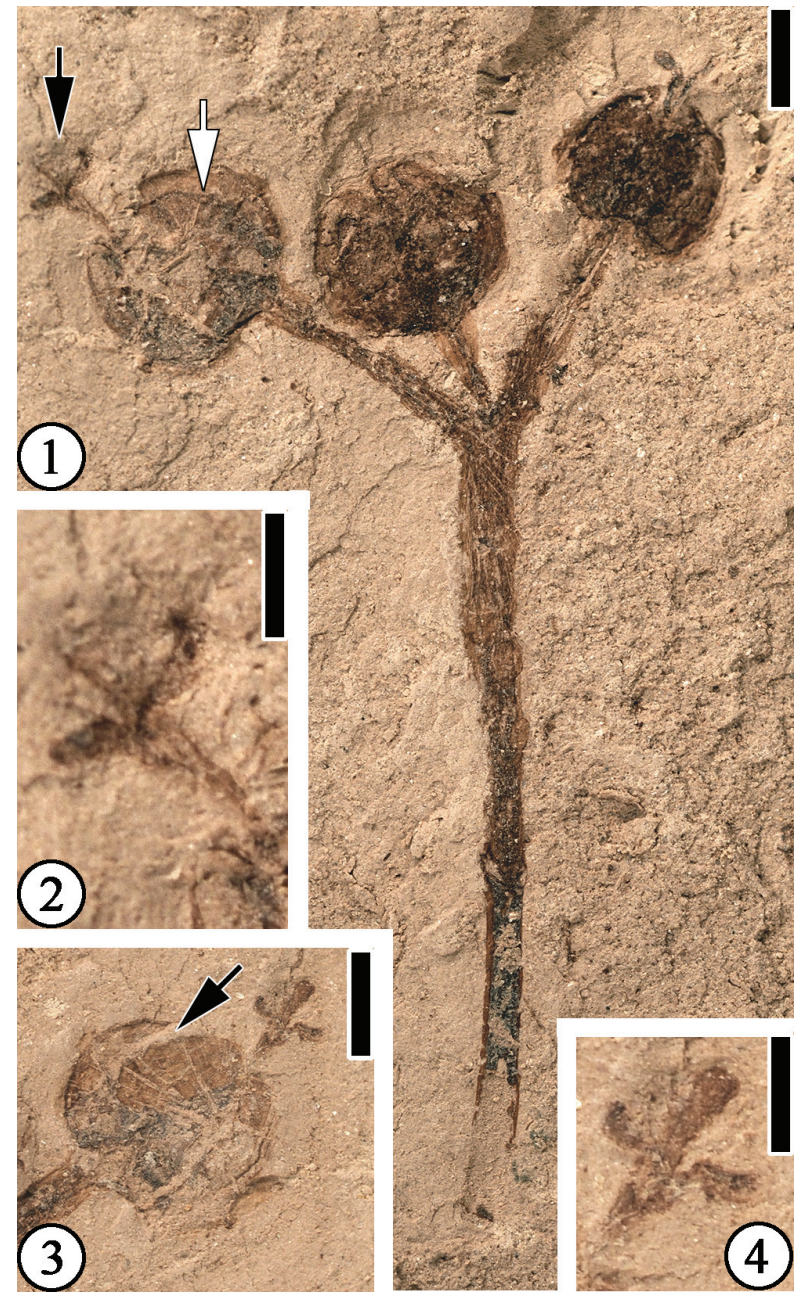

FIGURE 24. Paleopanax boldensis sp. nov.: 1) UF15738-059493. Showing one central acrocidal capsule flanked by two lateral, younger capsules and a long peduncle. Note dehiscence scar of the capsule (indicated by white arrow). Scale bar equals $2 \mathrm{~mm}$; 2) Enlargment of Figure 24.1 (indicated by black arrow) to show persistent apical style. Scale bar equals $1 \mathrm{~mm}$; 3 ) UF15738-059493'. Counterpart of Figure 24.1 showing persistent style and dehiscence gap (indicated by arrow. Scale bar equals $2 \mathrm{~mm}$; 4) Enlargement of Figure 24.3 to show the three branches of the style. Scale bar equals $1 \mathrm{~mm}$.

nax eocenensis Dilcher and Dolph, 1970, have been reported from other Claiborne localities (Dilcher and Dolph, 1970). Araliaceous woody racemes of globose infructescences were also reported from the late Eocene or early Oligocene Florissant flora, Colorado (Manchester, 2001).

The middle capsule seems to be the oldest among the three fruits because the styles had already fallen off before preservation. The two lateral fruits still have their styles attached. The num- ber of locules in each fruit is unknown. Based on the impression of UF15738-059493' (Figure 24.34 ), at least three are present. The number of seeds in each locule is also unknown. Based on the impressions of UF15738-059493' (Figure 24.3-4) and UF15738-059493 (Figure 24.1), it seems each locule bears only one seed.

The D-shaped carpel and the fruit size of the Bolden specimen is similar to the specimens that Berry (1930) described as Rubiacites wilcoxensis (Bell City pit, Calloway County, Kentucky; p. 133, plate 45, figure 8) and Rubiacites sphericus (Bell City pit, Kentucky; p. 133, plate 45, figure 10). The Rubiacites wilcoxensis specimen does seem to have an epigynous disc but it does not appear to be dehiscent. The other two specimens Berry (1930) described as Rubiacites sphericus (Bradley pit and Puryear pit, Tennessee; p. 133, plate 45, figures 9,11$)$ are larger. All specimens described by Berry do not have persistent styles.

The size of the capsules from the Bolden locality is similar to that of the fruits of Decodon gibbosus (E. Reid) E. Reid in Nitikin (Lythraceae) reported from the early Miocene of northern Bohemia (Kvaček and Sakala, 1999, p. 205, figure 3). They differ in that the pedicellate capsules of $D$. gibbosus are axillary and that each capsule contains at least 10 seeds.

\section{Angiosperm Incertae Sedis - Flowers

$$
\begin{gathered}
\text { cf. "Solanites" saportanus (Berry) } \\
\text { Martínez-Millán, } 2010
\end{gathered}
$$ \\ (Figure 25)}

v. 1916b Solanites saportana Berry, p. 348, pl. 106, figs. 4-5.

v. 2010 Solanites saportanus (Berry); MartínezMillán, p. 166-167, fig. 3.3 A-C.

v. 2014 Solanites saportanus (Berry); Millan and Crepet, p. 79-80, fig. 3 a-b.

Description. Flower 6-merous, $9 \mathrm{~mm}$ in diameter, with a shallow floral cup ca $4 \mathrm{~mm}$ in diameter. Perianth parts (sepals?) triangular, $3 \mathrm{~mm}$ long and 2 $\mathrm{mm}$ wide at the base; a midvein present in each part. Pedicel present, ca $0.5 \mathrm{~mm}$ in diameter.

Number of specimens examined. 1. UF15737008222.

Remarks. Solanites is a fossil genus established by Saporta (1862; see Martínez-Millán, 2010 and Millan and Crepet, 2014 for nomenclatural history) for actinomorphic, 5-merous, gamopetalous flowers with five stamens (short filaments and elongated anthers) alternating with the petals. The type species is Solanites brongniartii. Saporta (1862) assigned several members of the genus to the 

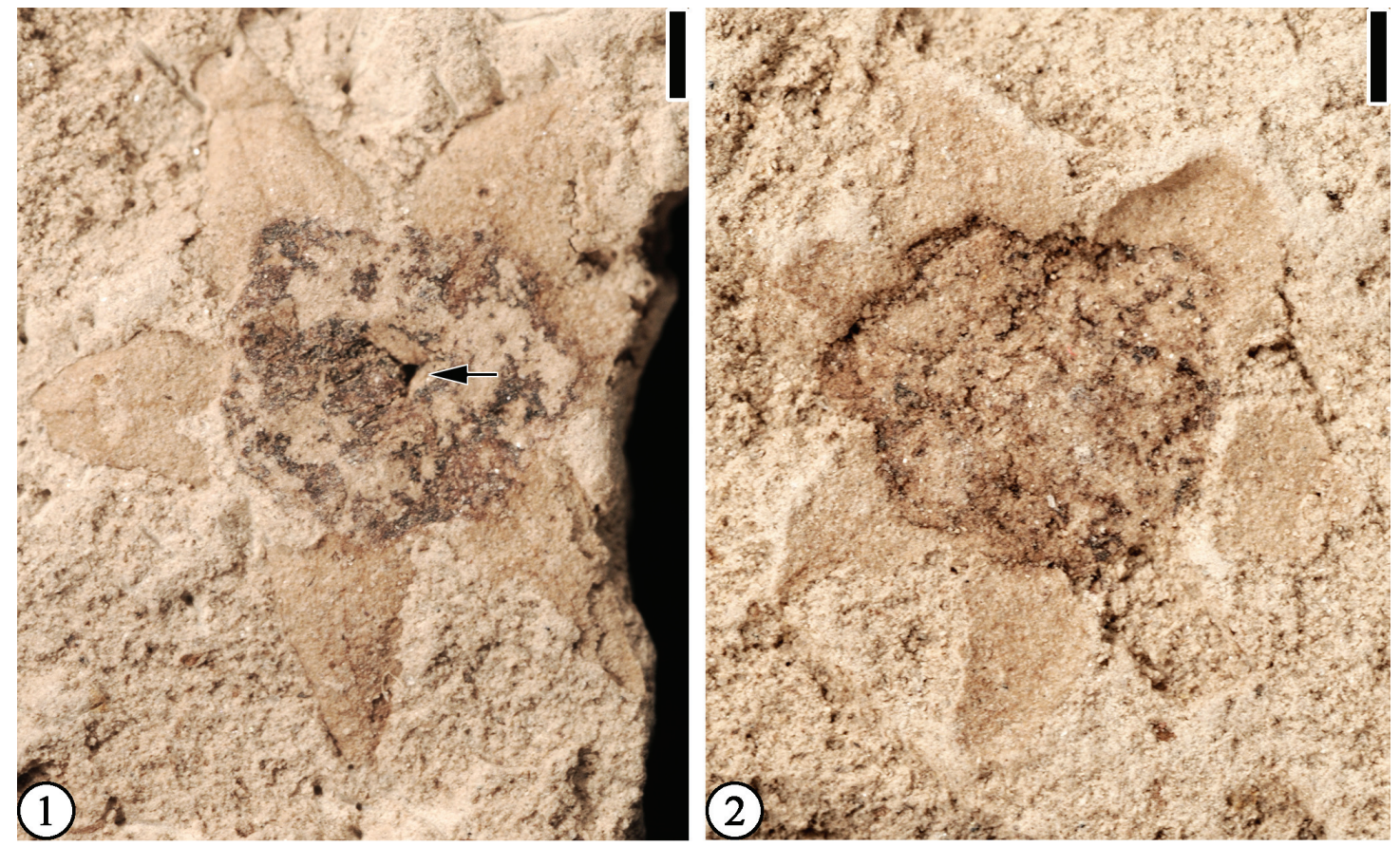

FIGURE 25. "Solanites" saportanus (Berry) Martínez-Millán, 2010: 1) UF15737-008222. Vertically compressed flower showing six perianth parts and pedicel (indicated by arrow). Note that each perianth part has a midvein and two or three faint lateral veins. Scale bar equals $1 \mathrm{~mm}$; 2) UF15737-008222'. Counterpart of Figure 25.1 showing bases of six perianth parts. Scale bar equals $1 \mathrm{~mm}$.
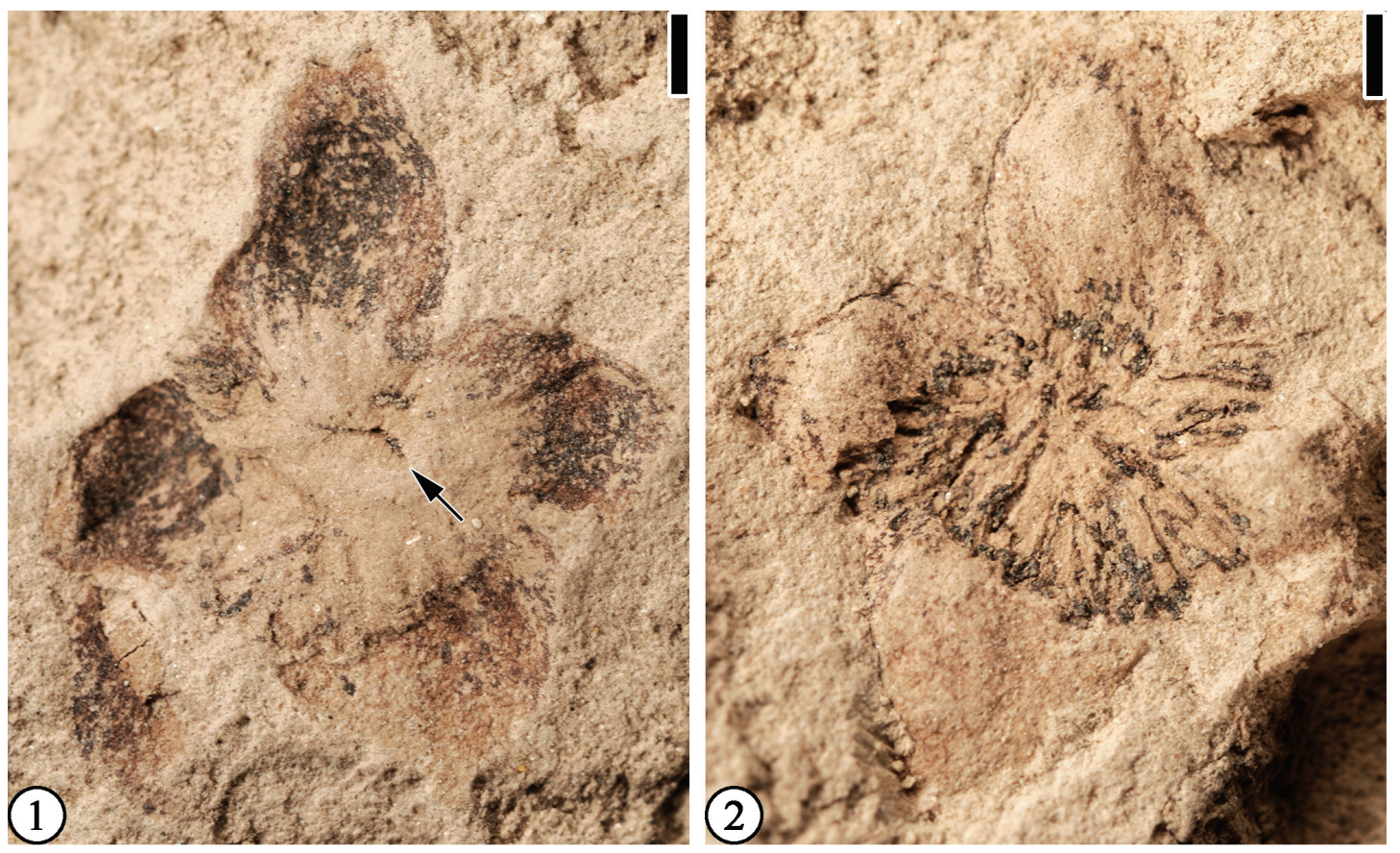

FIGURE 26. "Solanites" sarachaformis Berry, 1930: 1) UF15737-049569. Vertically preserved flower showing four floral parts each with four or five converging veins and pedicel (indicated by arrow). Scale bar equals $1 \mathrm{~mm}$; 2) UF15737049569'. Counterpart of Figure 26.1 showing a shallow floral cup formed by fusion of basal portions of the four floral parts. Note relatively strong veins extend to the center of the cup. Scale bar equals $1 \mathrm{~mm}$. 

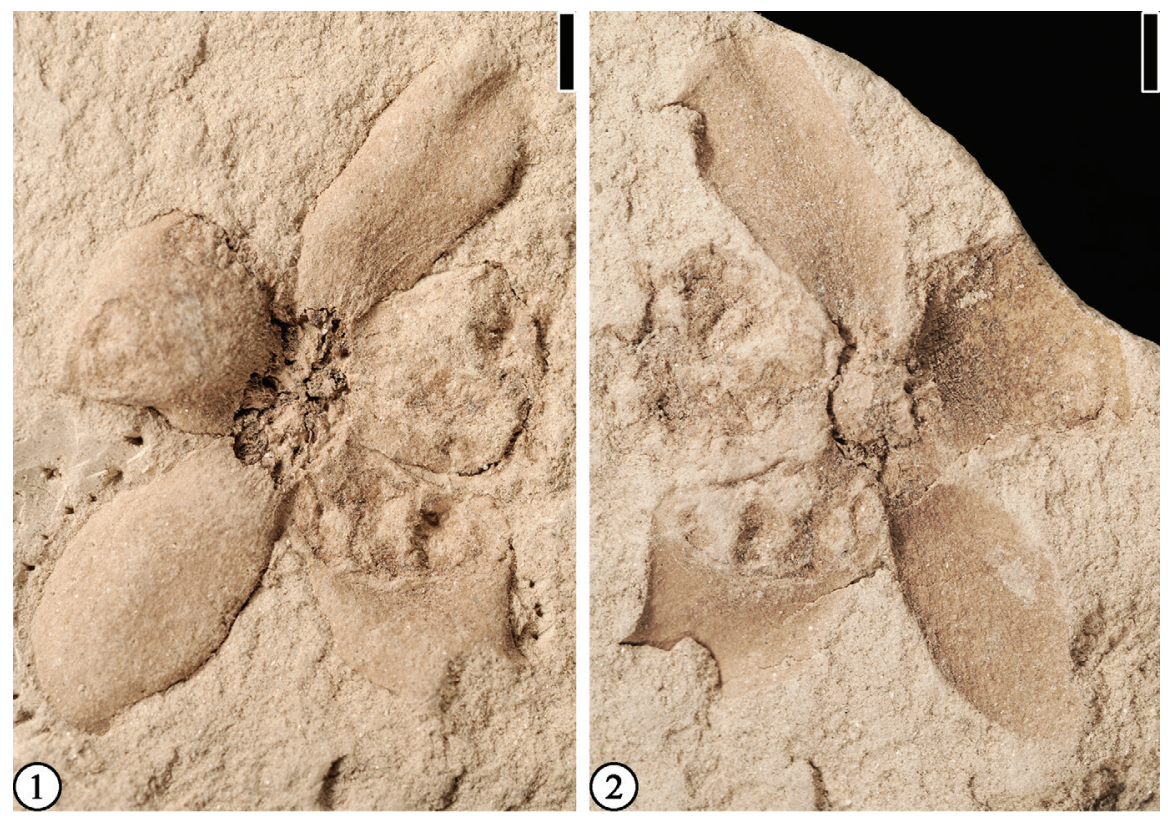

FIGURE 27. Claiborne Floral Type 5: 1-2) UF15738-008216, 008216'. Part and counterpart of a specimen showing five perianth parts and an ovary. Scale bar equals $2 \mathrm{~mm}$.

Solanaceae. However, phylogenetic analysis (Martínez-Millán, 2010; Millan and Crepet, 2014) suggests that the genus is best placed as Incertae Sedis within the Euasterids.

Berry (1916b) described one specimen from the Holly Springs locality, Tennessee, as Solanites saportana. Martínez-Millán (2010) and Millan and Crepet (2014) corrected the species epithet and changed the species name to $S$. saportanus and noted that the only feature it shares with the type species, S. brongniartii, is pentamery. They further suggested that this and three other species from North American be removed from the genus because they show little resemblance to the type species.

The presence of a pedicel on the Bovay specimen is indicated by the depression at the center of the floral cup. It is similar to the two flowers described by Berry (1916b) in having a shallow floral cup and a midvein in each floral part. However, it differs from Berry's specimens in having six floral parts.

\section{"Solanites" sarachaformis Berry, 1930}

(Figure 26)

v. 1930 Solanites sarrachaformis Berry, p. 131; pl. 25, fig. 31.

Description. A vertically preserved flower about $10 \mathrm{~mm}$ in diameter. Four perianth parts (sepals?) present, each part ovate, ca $4.5 \mathrm{~mm}$ long, and 3.5 $\mathrm{mm}$ wide; 5 veins present on each part. A shallow floral cup present, formed by fusion of the basal $20 \%$ of floral parts.

Number of specimens examined. 1. UF15737049569.

Remarks. Based upon Article 60 (Section 1, Chapter IX) of the International Code of Nomenclature for Algae, Fungi, and Plants (McNeill et al., 2012), Martínez-Millán (2010) noted the typographical error of Berry (1930) and corrected the species epithet from sarrachaformis to sarachaformis. This specimen is similar to the one described by Berry (1930) from the Holly Springs, Mississippi locality (Berry, 1930; p. 131, plate 25, figure 31) except

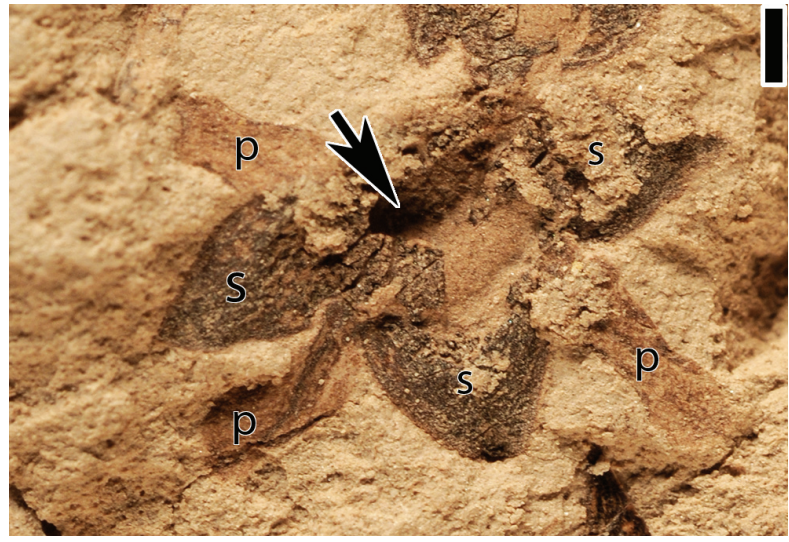

FIGURE 28. Claiborne Floral Type 7. UF15737059208a. A flower showing three sepals (s), three petals (p), and an ovary (indicated by arrow). Scale bar equals $1 \mathrm{~mm}$. 

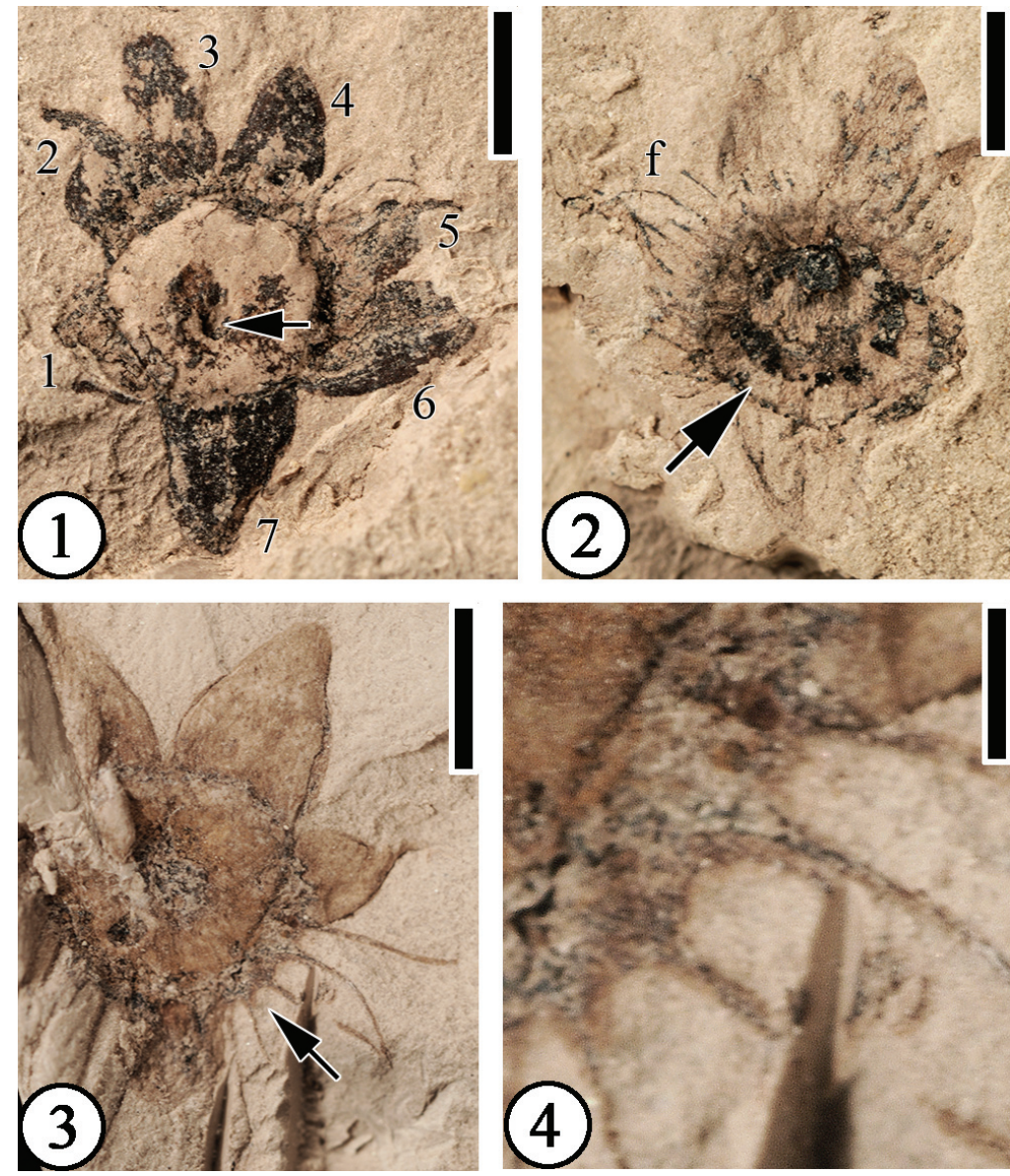

FIGURE 29. Claiborne Floral Type 8: 1) UF15737-049570. Specimen showing seven floral parts (indicated clockwise by numbers) and a pedicel (indicated by arrow). The eighth floral part is proably positioned between 6 and 7 . Scale bar equals $2 \mathrm{~mm}$; 2) UF15737-049570'. Counterpart of Figure 29.1 showing two filaments (f) and the hypanthium rim (indicated by arrow). Scale bar equals $2 \mathrm{~mm}$; 3) UF15737-049567a. Flower showing three floral parts of different sizes and five filaments attached to the hypanthium rim (indicated by arrow). Scale bar equals $2 \mathrm{~mm}$; 4) Enlargement of Figure 29.3 to show attachment of filaments. Scale bar equals $0.5 \mathrm{~mm}$.

that it has four floral parts. The species differs from the other two species, i.e., cf. "Solanites" saportanus (Berry) Martínez-Millán and "Solanites" pusillus Berry, in having an inconspicuous floral cup (Table 4).

\section{Claiborne Floral Type 5}

(Figure 27)

Description. Vertically preserved flower $2.2 \mathrm{~cm}$ in diameter showing five separate ovate, finely veined perianth parts; the most complete being $7 \mathrm{~mm}$ long and $5 \mathrm{~mm}$ wide at the widest point with a rounded apex. Ovary $5 \mathrm{~mm}$ in diameter.

Number of specimens examined. 1. UF15738008216.

Remarks. Fifteen specimens have been discovered from the Warman clay pit, Tennessee (Wang et al., 2013). The venation of the floral parts on this specimen from Bolden clay pit, Mississippi, is not as well preserved as that of the Warman specimens. Many depressions on one part of the central column may represent the attachment scars of the stamens. We assign this specimen to Claiborne Floral Type 5 based on the size of the flower and the shape and number of perianth parts (Table 4).

\section{Claiborne Floral Type 7 \\ (Figure 28)}

Description. Flower ca. $11 \mathrm{~mm}$ in diameter, vertically preserved showing three petals alternating with three sepals. Ovary inferior, $3 \mathrm{~mm}$ in diameter; sepals triangular, $3 \mathrm{~mm}$ long and $2 \mathrm{~mm}$ wide, apex acute; petals $4 \mathrm{~mm}$ long and $1 \mathrm{~mm}$ wide.

Number of specimens examined. 1. UF15737059208a.

Remarks. The sepals and petals seem to be attached to the rim of the depression, indicating an inferior ovary. The petals slightly overlap the adja- 

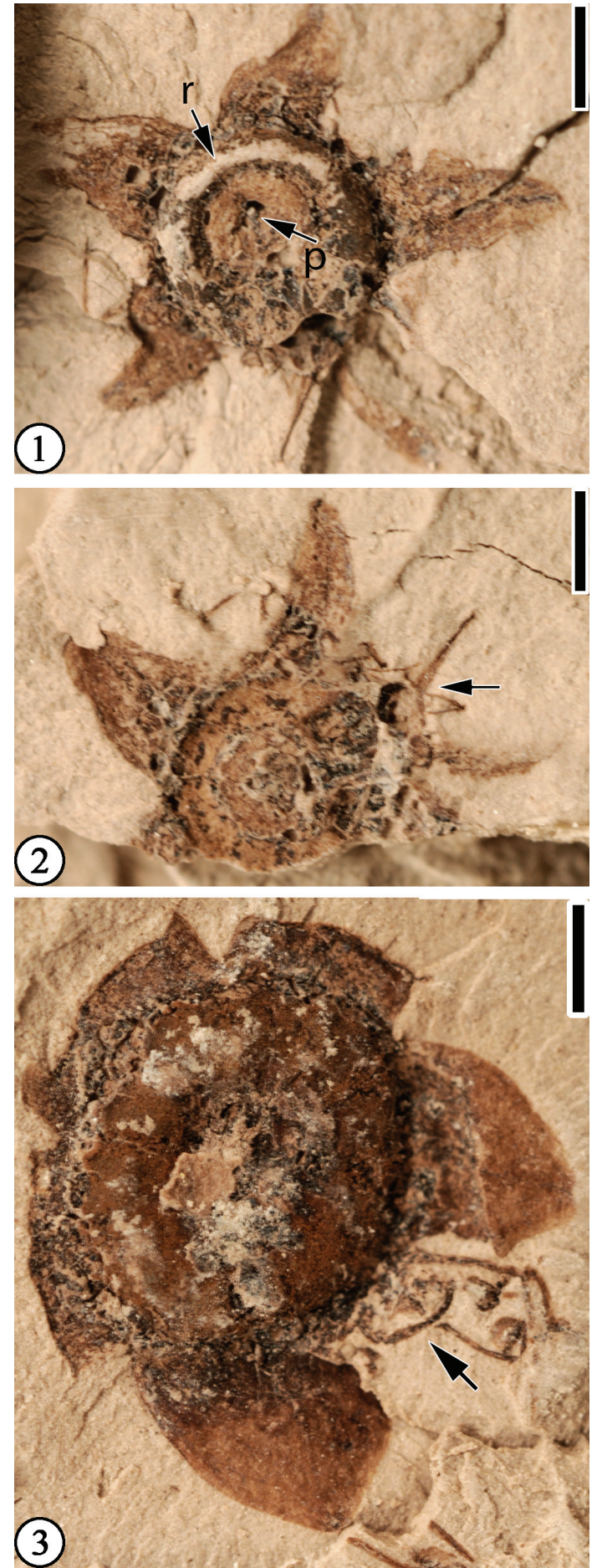

FIGURE 30. Claiborne Floral Type 9: 1) UF15737059240. Flower showing five floral parts, floral rim ( $r$ ), and pedicel (p). Scale bar equals $1 \mathrm{~mm}$; 2) UF15737059240'. Counterpart of Figure 30.1 showing two filaments (indicated by arrow) and impression of an ovary rim defined by two dark concentric rings with the pedicel impression at the center. Scale bar equals $1 \mathrm{~mm}$; 3 ) UF15737-059247. Flower showing several filaments attached to the floral rim (arrow). Scale bar equals 1 $\mathrm{mm}$.

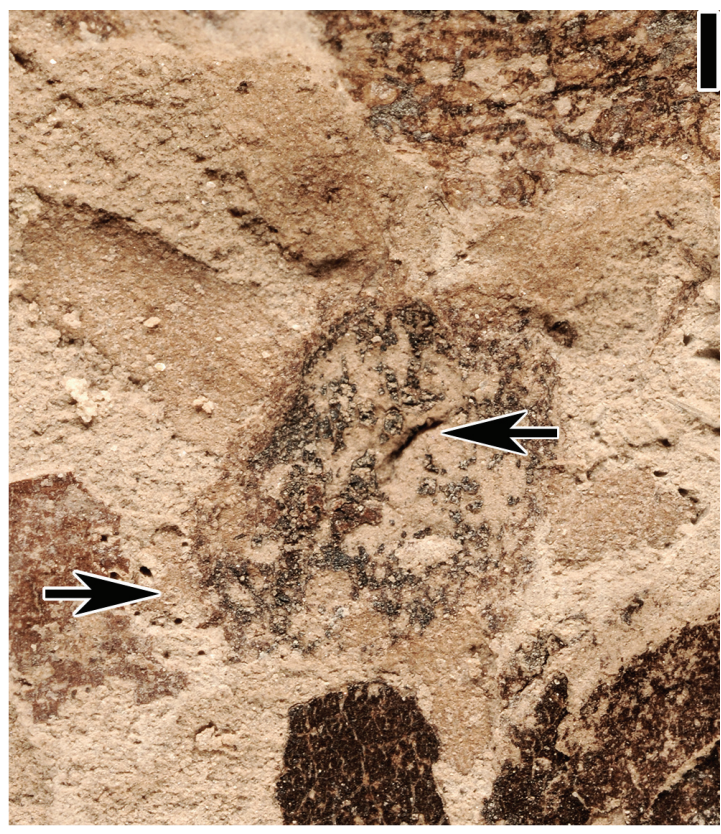

FIGURE 31. Claiborne Floral Type 10. UF15737059243b. Vertically preserved flower showing six perianth parts, ovary (dark area), and pedicel (indicated by arrow on the right). The sixth perianth part is indicated by the arrow on the left. Scale bar equals $1 \mathrm{~mm}$.

cent sepals. The presence of an ovary is indicated by the hole at the center of the depression.

\section{Claiborne Floral Type 8 \\ (Figure 29)}

Description. Flower $8 \mathrm{~mm}$ in diameter, consisting of at least seven perianth parts, an ovary within a hypanthium with a thickened rim, stamens, and a pedicel. Perianth parts triangular, $1.5-2.5 \mathrm{~mm}$ long and $1.5-2 \mathrm{~mm}$ wide, trichomes present; each with at least five relatively strong veins. Ovary $2 \mathrm{~mm}$ in diameter, trichomes present; hypanthium rim ca. $0.5 \mathrm{~mm}$ thick. Four or five stamens observed, attached to hypanthium rim; filaments ca $2.5 \mathrm{~mm}$ long and $0.1 \mathrm{~mm}$ wide. Pedicel $0.5 \mathrm{~mm}$ in diameter. Number of specimens examined. 2. UF15737049567a, 049570.

Remarks. It is difficult to separate these perianth parts into sepals and petals. Although only seven floral parts are observed on one specimen, their arrangement on the rim indicates probable presence of an eighth perianth part (Figure 29.1-2; Table 4). The presence of a pedicel is indicated by the depression at the center of the compressed flower (Figure 29.1). It seems that at least four or five stamens are attached at the base of each sepal/petal (Figure 29.3-4).

\section{Claiborne Floral Type 9}

(Figure 30) 

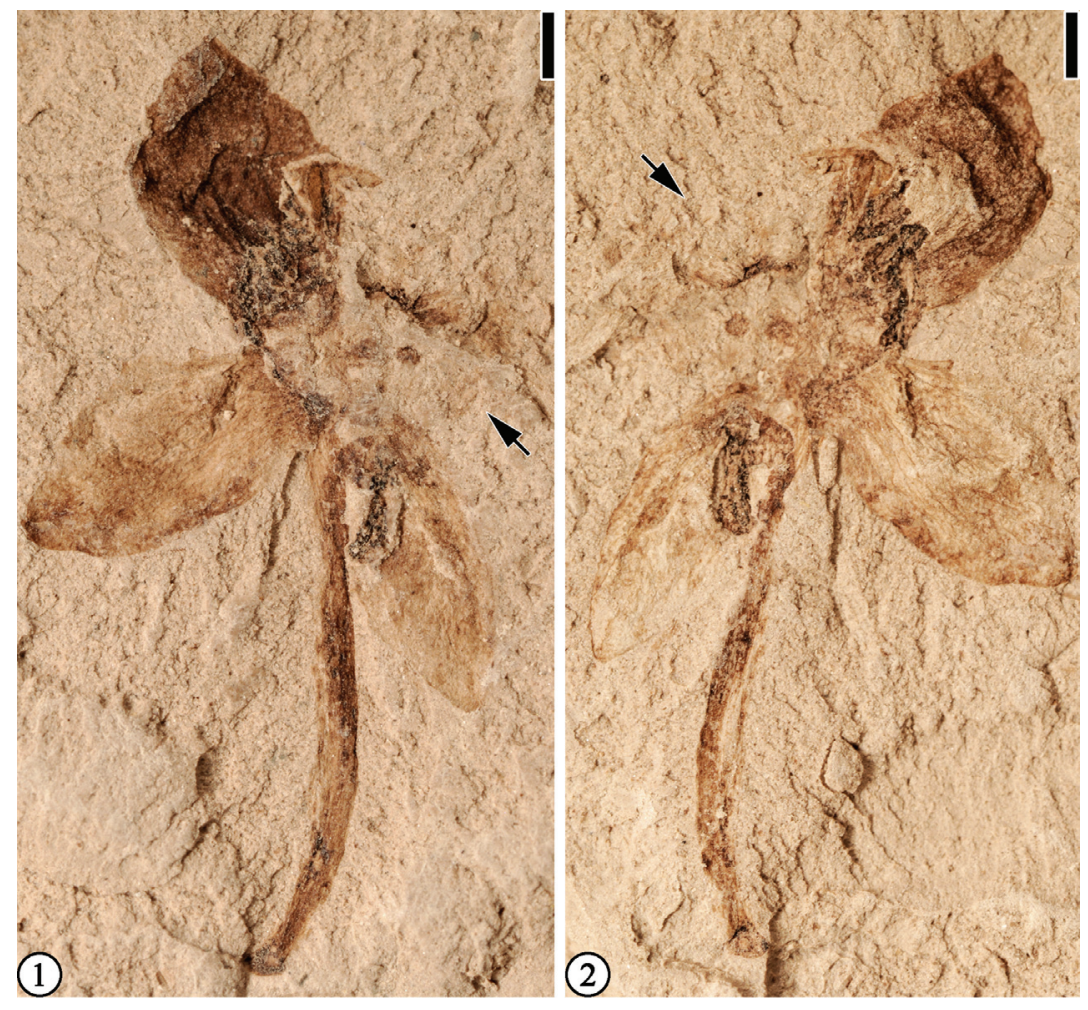

FIGURE 32. Claiborne Floral Type 11 (1-2), UF15737-008227, 008227'. Part and counterpart of a specimen showing a flower with three floral parts and a long pedicel. Arrows point to the gap between two adjacent floral parts, indicating the possible presence of the fourth floral part. Scale bar equals $1 \mathrm{~mm}$.

Description. Vertically preserved flower $6 \mathrm{~mm}$ in diameter with five perianth parts; perianth parts separate, $2 \mathrm{~mm}$ long, and $1 \mathrm{~mm}$ wide, triangular, acute at apices. Ovary $2-3 \mathrm{~mm}$ in diameter, with a prominent rim at least $0.5-1 \mathrm{~mm}$ thick. A pedicel present, ca. $0.2 \mathrm{~mm}$ wide.

Number of specimens examined. 2. UF15737059240; 059247.

Remarks. The presence of a pedicel is indicated by a central depression on one part of the specimen (Figure 30.1) and a central small circle on the counterpart specimen. The thickness of the ovary rim is defined by the two concentric outer circles (Figure 30.3). The prominent ovary (hypanthium) rim of this specimen is similar to Solanites pusillus Berry (also see Wang, et al., 2013, p. 41, figure 35; Table 4). However, they differ in that the perianth parts do not have a midvein. The ovary rim is also similar to that of a flower from Webb County, Texas, described as "Diospyros" mirafloriana by Berry (1924, p. 195, plate 40, figure 5) and Ball (1931, p. 170, plate 32, figure 5). They differ in that the flower reported by Berry is almost five times larger. This flower differs from Eoglandulosa warmanensis (Taylor and Crepet, 1987, figures 1$6,9-13,33,34$; Wang et al., 2013, figure 21) in that the flower from Bovay is smaller, the floral parts are separate, and the trichomes are absent from all floral parts.

\section{Claiborne Floral Type 10}

(Figure 31)

Description. Flower 6-merous, vertically preserved, ca $15 \mathrm{~mm}$ in diameter; perianth parts (petals?), ovate, about $5 \mathrm{~mm}$ long, and $2-2.5 \mathrm{~mm}$ wide; faint veins present. Inferior (?) ovary about $5 \mathrm{~mm}$ in diameter.

Number of specimens examined. 1. UF15737059243b.

Remarks. The perianth parts do not seem to overlap, and they seem to be attached to the upper rim of the compressed ovary, indicating an inferior ovary. This flower is similar to "Solanites" saportanus (Berry) Martínez-Millán in that both flower types are 6-merous. They are different in that the floral parts of "Solanites" saportanus (Berry) Martínez-Millán are triangular and possess a prominent midvein (Table 4). The shape of the perianth parts of this 6-merous flower is similar to those of Wuyunanthus hexapetalus Wang, $\mathrm{Li}, \mathrm{Li}$, and $\mathrm{Fu}$, 2001, a flower described from the Paleocene Wuyun Formation from northeast China. They dif- 

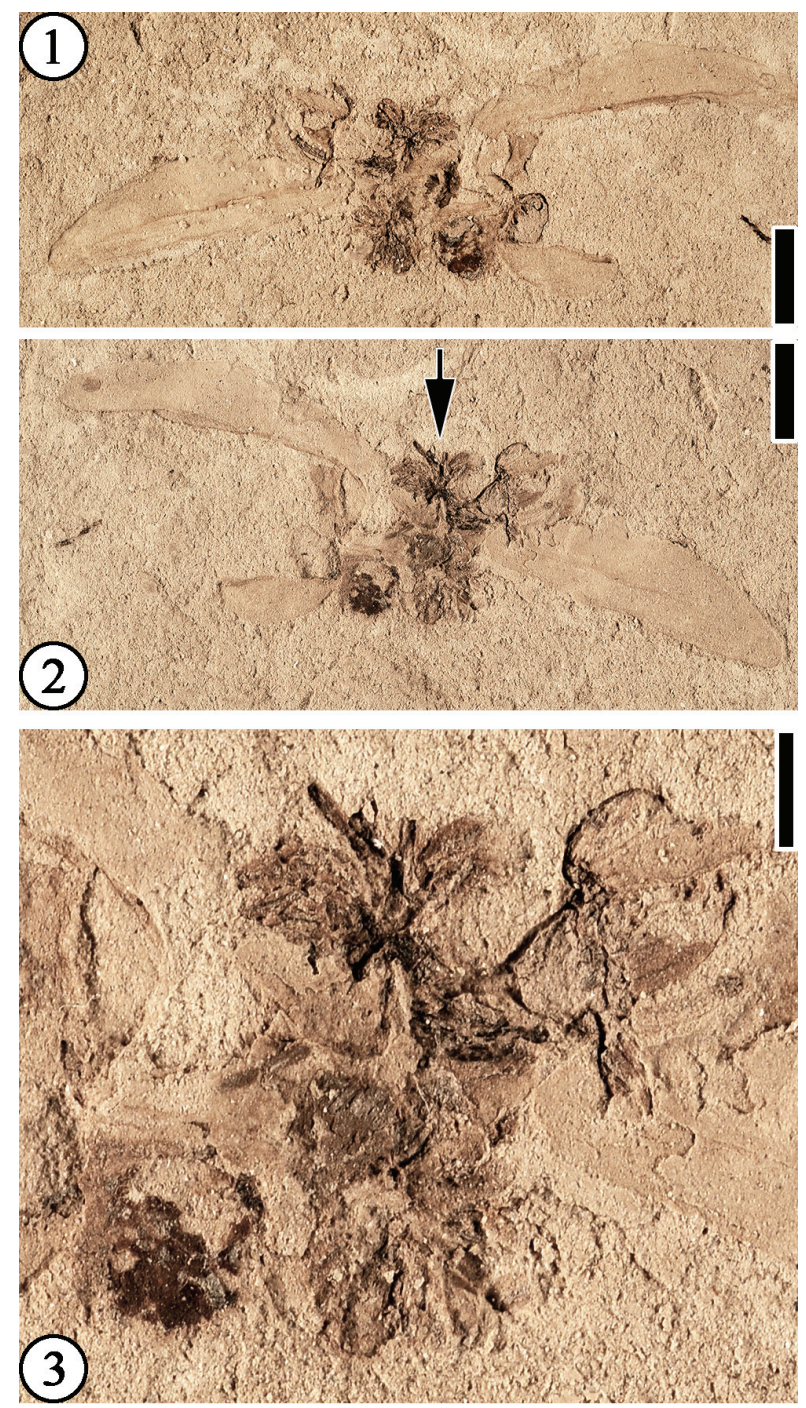

FIGURE 33. Claiborne Floral Type 12: 1-2) UF15738008217, 008217'. Part and counterpart of a specimen showing a cluster of vertically and laterally compressed flowers subtended by two large bracts or leaves. Scale bar equals $5 \mathrm{~mm}$; 3) Enlargement of Figure 33.2 (indicated by arrow) to show flowers. Scale bar equals $2 \mathrm{~mm}$.

fer in that the flower from Bovay, Mississippi, is smaller and it does not have a hexagonal disk.

\section{Claiborne Floral Type 11}

(Figure 32)

Description. Vertically preserved flower ca $11 \mathrm{~mm}$ in diameter with four perianth parts and a long pedicel. Perianth parts ovate in outline, separate, 5 $\mathrm{mm}$ long, and $3 \mathrm{~mm}$ at middle. Pedicel $10 \mathrm{~mm}$ long and $0.5 \mathrm{~mm}$ wide. Ovary ca $2 \mathrm{~mm}$ in diameter.

Number of specimens examined. 1. UF15737008227.
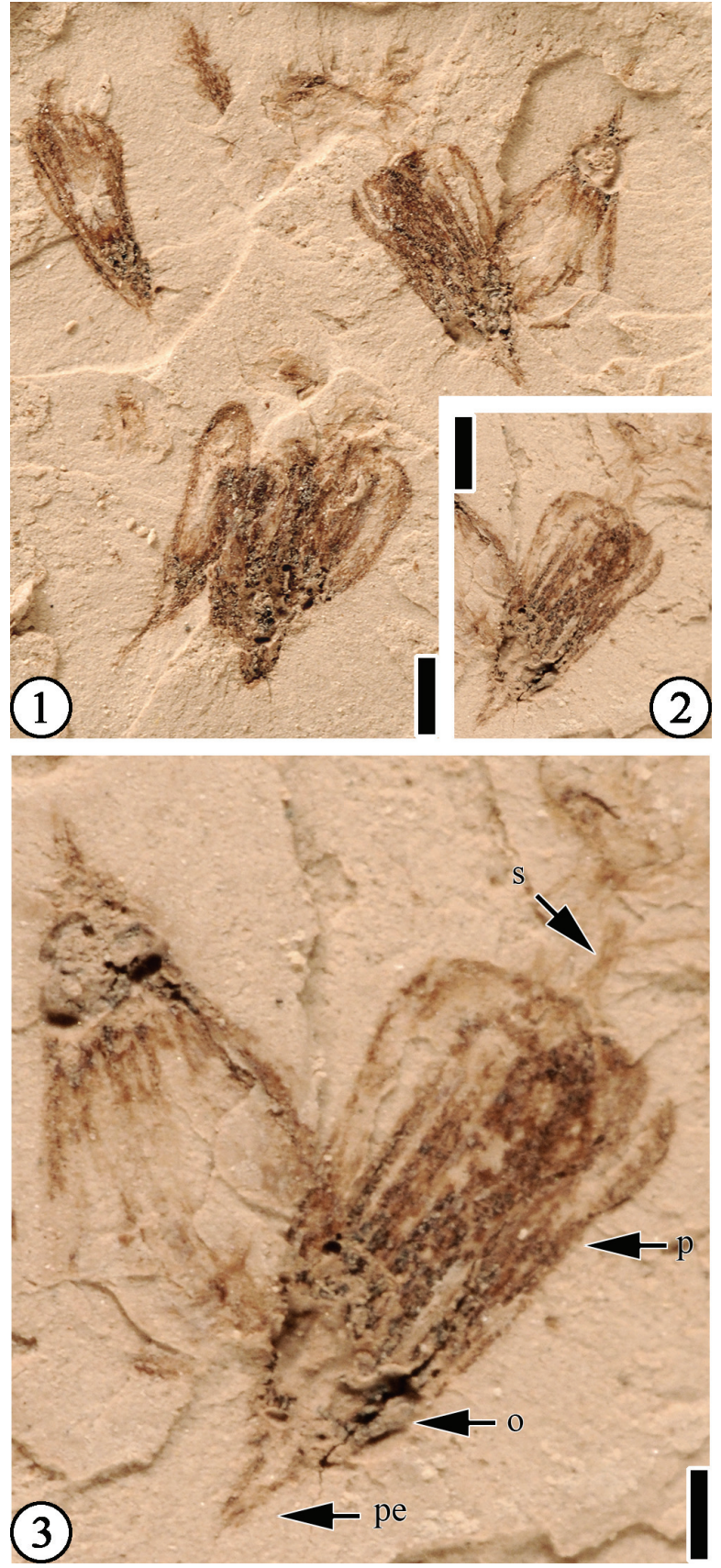

FIGURE 34. Claiborne Floral Type 13: 1-2) UF15737059232, 059232'. Part and counterpart of a specimen showing dispersed, laterally compressed flowers. Scale bar equals $1 \mathrm{~mm}$; 3) Enlargement of Figure 34.2 to show pedicel (pe), ovary (o), perianth ( $p)$, and styple (s) of the flower. Scale bar equals $0.5 \mathrm{~mm}$.

Remarks. The pedicel seems to be very thin. It is possible that it represents a long exserted style of a flower. It is also possible that this flower may be 3-merous. But based upon its asymmetry and the 


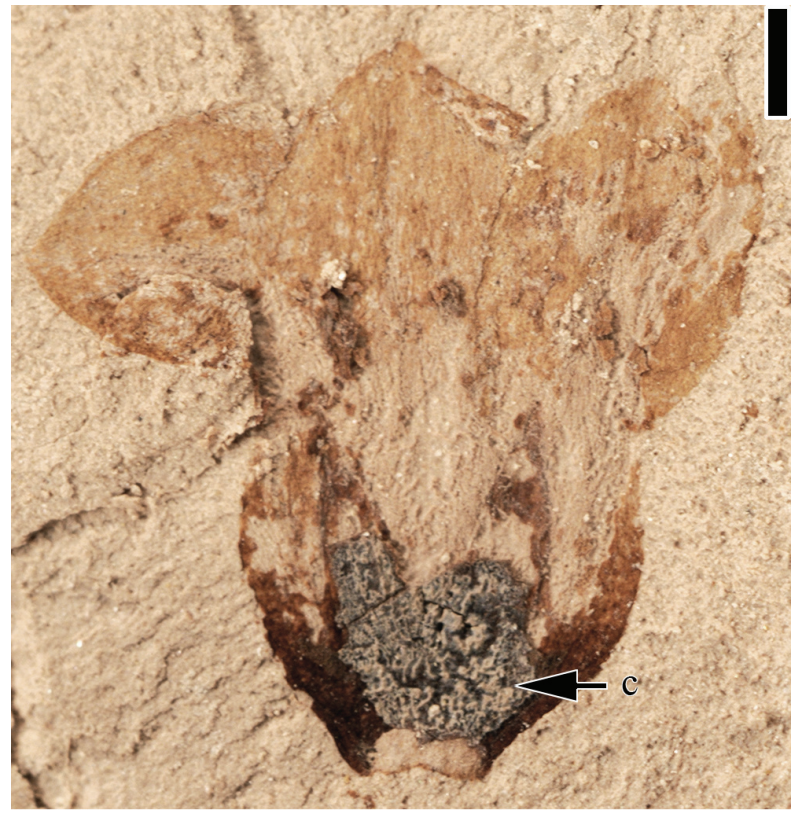

FIGURE 35. Claiborne Floral Type 14, UF15738052528. Showing sympetalous, small flower with a cupuliform perianth tube. Note three perianth lobes and remnant of calyx (c). Scale bar equals $1 \mathrm{~mm}$.

large gap between two adjacent floral parts (Figure 32.1), we conclude that this flower possesses four floral parts. Table 4 summarizes the descriptions of Claiborne Floral Types 5, 8-11 and also "Diospyros" mirafloriana, Eoglandulosa warmanensis, "Solanites" pusillus, "Solanites" saportanus, and "Solanites" sarachaformis. These taxa/morphotypes are similar in their vertical preservation and radial symmetry. It is likely that most have a hypanthium.

\section{Claiborne Floral Type 12}

(Figure 33)

Description. A cluster of vertically and laterally compressed flowers subtended by two large (ca $1.8 \mathrm{~cm}$ long and $5 \mathrm{~mm}$ wide) bracts/leaves and one small, incomplete bract/leaf; the two large bracts/ leaves emerging $180^{\circ}$ apart. One laterally compressed flower ca $7 \mathrm{~mm}$ long (including pedicel) and $7 \mathrm{~mm}$ wide; ovary inferior, obconic, ca $2 \mathrm{~mm}$ long, and $2 \mathrm{~mm}$ wide; pedicel short, ca $1.5 \mathrm{~mm}$ long and $0.5 \mathrm{~mm}$ wide. Perianth not well preserved. No other floral parts present. A second laterally compressed floral structure appears to be in a later developmental stage, showing a possible developing fruit ca $3 \mathrm{~mm}$ in diameter. Anthers observed only in vertically compressed flowers; anthers ca 2 $\mathrm{mm}$ long and $1 \mathrm{~mm}$ wide; filaments not observed. A prominent midvein present on the two large bracts/ leaves.

Number of specimens examined. 1. UF15738008217.

Remarks. This cluster of flowers is unique in that it is subtended by at least three bracts or leaves. The cluster could be a mixture of staminate and pistillate flowers.

\section{Claiborne Floral Type 13}

(Figure 34)

Description. Small, laterally preserved flowers about $3.5 \mathrm{~mm}$ long, $2 \mathrm{~mm}$ wide at the apex of the closed or fused perianth, and $1 \mathrm{~mm}$ wide at the base. Style $0.5 \mathrm{~mm}$ long; filaments $2 \mathrm{~mm}$ long. Pedicel short, $0.5 \mathrm{~mm}$ long.

Number of specimens examined. 1. UF15737059232.

Remarks. A total of six small, dispersed, laterally preserved flowers are observed. One flower shows exserted filaments about $2 \mathrm{~mm}$ in length.

\section{Claiborne Floral Type 14}

(Figure 35)

Description. Laterally preserved flower, sympetalous, small, $7 \mathrm{~mm}$ long, and $6.5 \mathrm{~mm}$ wide at the distal portion. Perianth tube cupuliform, thin, with three lobes; simple trichomes present on entire perianth. Remnant of calyx observed at the base of the perianth tube.

Number of specimens examined. 1. UF15738052528.

Remarks. This cupuliform perianth is unique among the flowers observed from the Claiborne Group. The presence of a calyx (or sepals) is inferred from the thick carbonaceous material at the base of the perianth tube. Flowers with cupuliform perianth tubes occur in many angiosperm families, such as some members of the Ericaceae and Lauraceae (Li et al., 2008).

\section{Claiborne Floral Type 15}

(Figure 36)

Description. Laterally preserved flower showing three separate (but not spreading) perianth parts about $2 \mathrm{~mm}$ long and 0.8-1.2 mm wide. Apex of each perianth part acute. Receptacle $1.5 \mathrm{~mm}$ wide and ca $1 \mathrm{~mm}$ high tapering to pedicel $1 \mathrm{~mm}$ long and $0.8 \mathrm{~mm}$ wide.

Number of specimens examined. 1. UF15737059251.

Remarks. This flower differs from Lauroflorum warmanensis (Wang et al., 2013, p. 4, figure 3) in having a very short pedicel and a much smaller size. The gross shape of the lateral view is similar 

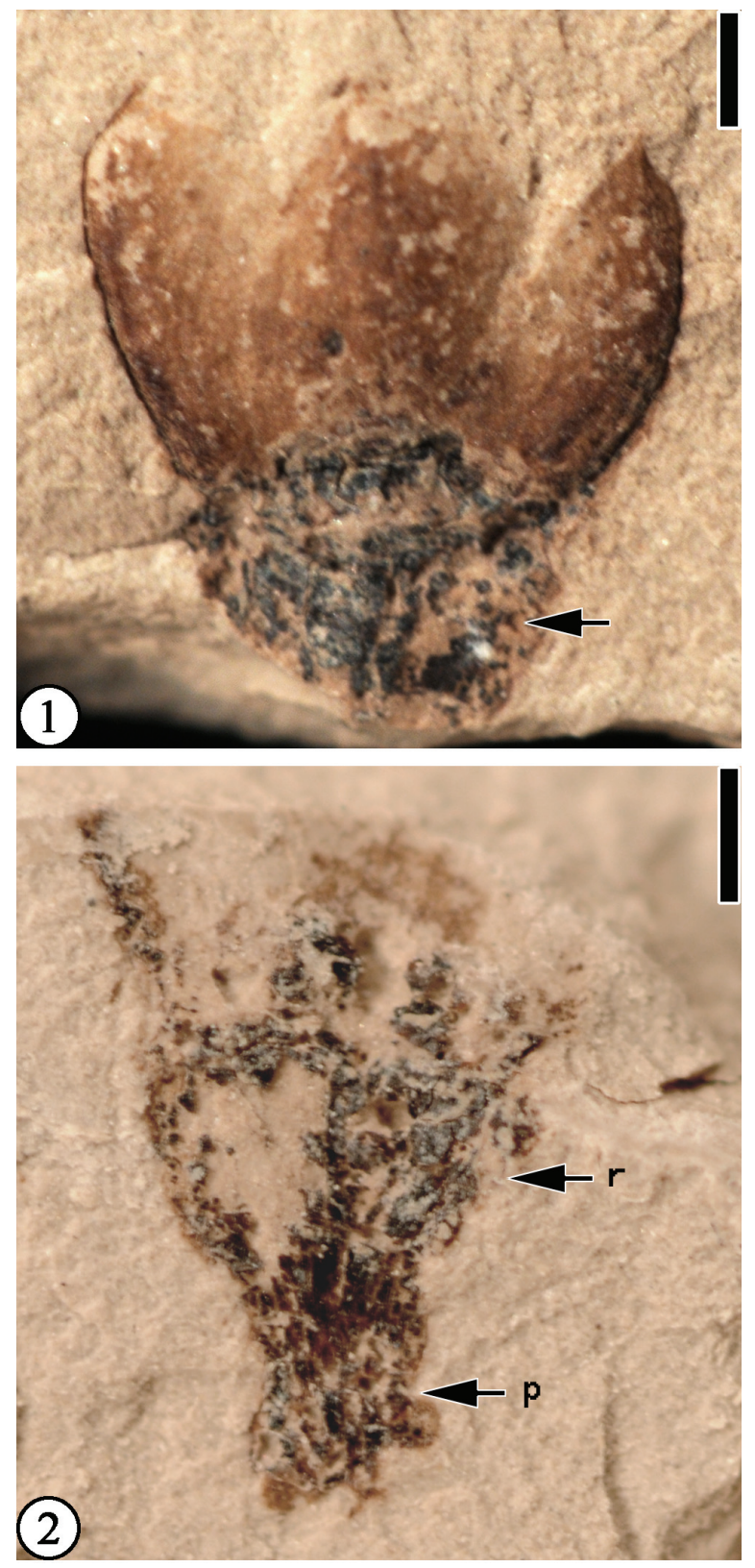

FIGURE 36. Claiborne Floral Type 15: 1) UF15737059251. Laterally preserved flower showing three separate perianth parts above and a receptacle (indicated by arrow). Scale bar equals $0.5 \mathrm{~mm}$; 2) UF15737-059251'. Counterpart of Figure 36.1 showing a receptacle $(r)$ and a pedicel (p). Scale bar equals $0.5 \mathrm{~mm}$.

to Claiborne Floral Type 1 and Claiborne Floral Type 2 (Wang et al., 2013, figure 36), but it is much smaller in size compared with the Warman flowers. The size and number of floral parts (three) of Laurophyllum florum Berry (1916b, plate 86, figure 6) seem to be similar to the Bovay flower, but Berry's (1916b) specimen is larger and has a much longer pedicel.

\section{Claiborne Floral Type 16 \\ (Figure 37)}

Description. Small laterally preserved floret 1.5 $\mathrm{mm}$ in diameter. Calyx fused at base with a shallowly lobed upper margin. Up to three perianth parts extend about $0.5 \mathrm{~mm}$ beyond the calyx. Ovary $1 \mathrm{~mm}$ in diameter. Style $0.5 \mathrm{~mm}$ long with an expanded stigmatic disc ca $0.3 \mathrm{~mm}$ wide. Pedicel very thin, ca $1-2.5 \mathrm{~mm}$ long and $0.2 \mathrm{~mm}$ wide.

Number of specimens examined. 2. UF15737059226, 059317.

Remarks. On one specimen (UF15737-059226), there are at least 18 scattered florets preserved together with an unknown floral structure.

\section{Claiborne Floral Type 17}

(Figure 38)

Description. Laterally preserved flower ca $10 \mathrm{~mm}$ long and $2.5 \mathrm{~mm}$ wide at widest point of the ovary; ovary obtriangular, $2 \mathrm{~mm}$ long and $2.5 \mathrm{~mm}$ wide; perianth parts elliptic, $4 \mathrm{~mm}$ long and $2 \mathrm{~mm}$ wide, with a prominent midrib. Filaments numerous, ca $4-5 \mathrm{~mm}$ long. Pedicel ca $3.5 \mathrm{~mm}$ long and $1 \mathrm{~mm}$ wide.

Number of specimens examined. 1. UF15738060634, 060634'.

Remarks. Table 2 shows the differences among Claiborne Fabaceae Floral Types 1 and 2, Protomimosoidea buchananensis, and Claiborne Floral Types 17 and 18.

\section{Claiborne Floral Type 18}

(Figure 39)

Description. Laterally preserved flower(s?) with ovary, stamens with partially fused filaments, and a short pedicel. Ovary spherical, $2 \mathrm{~mm}$ in diameter with several (four?) fragments of perianth attached, one extending $0.5 \mathrm{~mm}$ beyond the apex of the ovary. Filament column ca $2 \mathrm{~mm}$ long and $0.5 \mathrm{~mm}$ wide, with 4-6 anthers. Anthers $0.5-1 \mathrm{~mm}$ long and $0.5 \mathrm{~mm}$ wide, with strong connectives. Pedicel $1 \mathrm{~mm}$ long and $0.5 \mathrm{~mm}$ wide.

Number of specimens examined. 2. UF15737059323, 059241a.

Remarks. One specimen (Figure 39.2) shows a filament splitting from the central column. This indicates that distal portions of the filaments are separate (see Table 2).

\section{Claiborne Floral Type 19}

(Figure 40) 

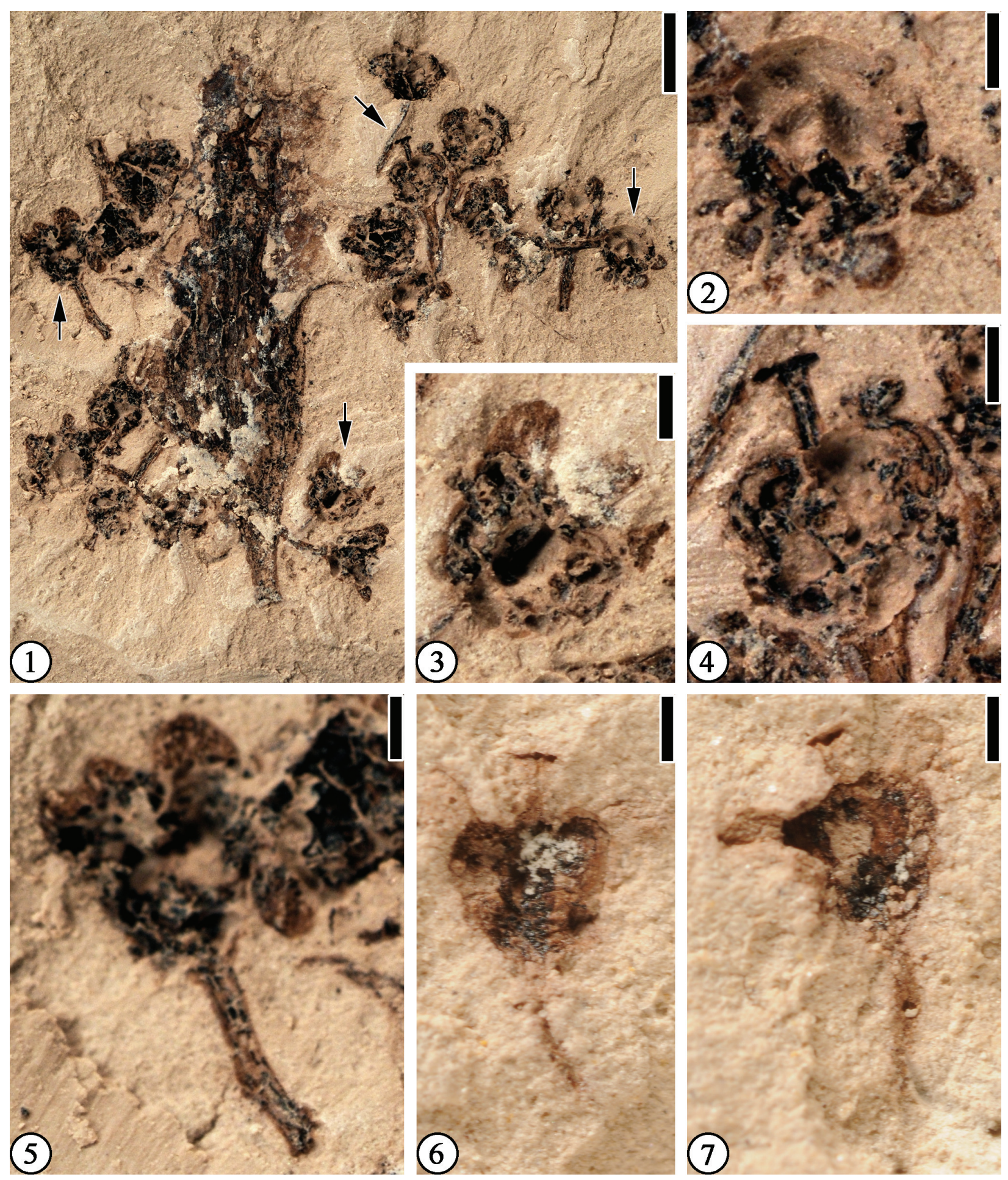

FIGURE 37. Claiborne Floral Type 16: 1) UF15737-059226. Showing at least 18 scattered florets (arrows) compressed with an unknown floral structure. Scale bar equals $2 \mathrm{~mm}$; 2) Enlargement of Figure 37.1 (indicated by right arrow) to show an individual flower. Scale bar equals $0.5 \mathrm{~mm}$; 3) Enlargement of Figure 37.1 (indicated by bottom arrow) to show a flower with inferior ovary and three perianth parts. Scale bar equals $0.5 \mathrm{~mm}$; 4) Enlargement of Figure 37.1 (indicated by top arrow) to show a stigmatic disc. Scale bar equals $0.5 \mathrm{~mm} ; 5$ ) Enlargement of Figure 37.1 (indicated by left arrow) to show pedicel and three perianth parts. Scale bar equals $5 \mathrm{~mm}$; 6-7) UF15737-059317, 059317'. Part and counterpart of a specimen showing two perianth parts, style and stigmatic disc, ovary, and pedicel. Scale bar equals $0.5 \mathrm{~mm}$. 

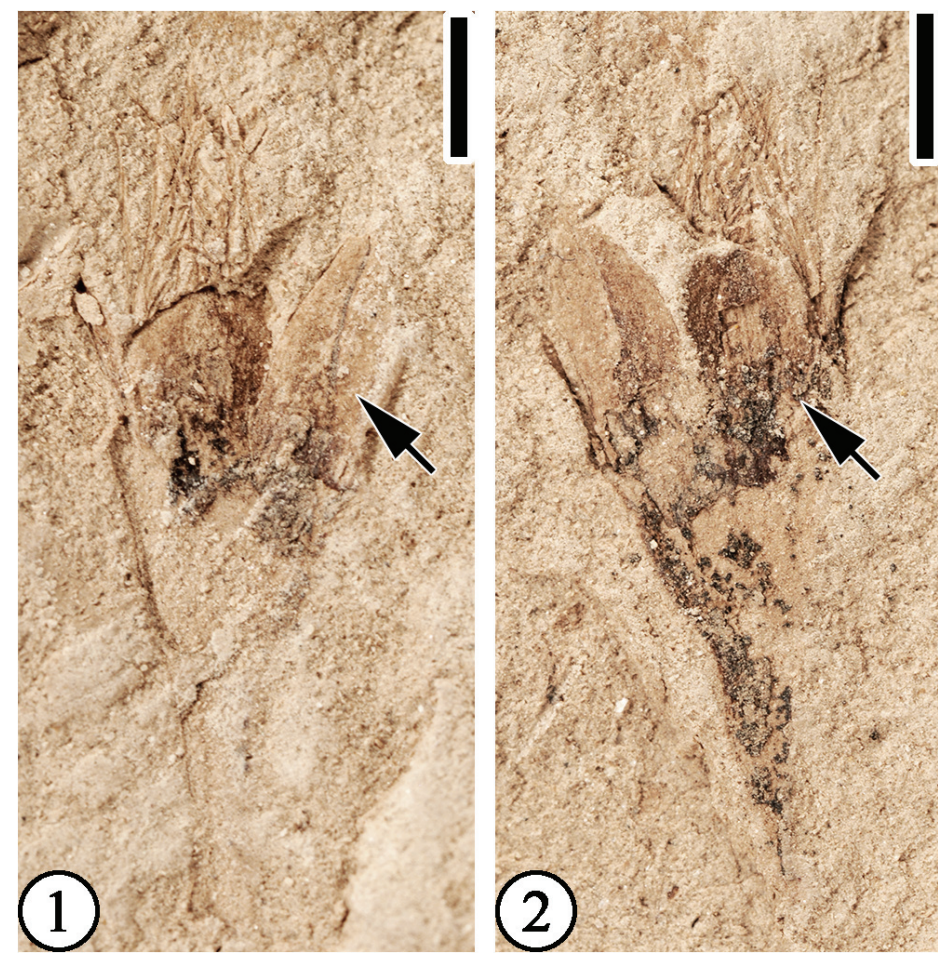

FIGURE 38. Claiborne Floral Type 17: 1) UF15738-060634. Laterally preserved flower showing a sepal with a prominent midvein (indicated by arrow) and numerous filaments. Scale bar equals 2 mm; 2) UF15738-060634'. Counterpart of Figure 38.1 showing a petal (indicated by arrow). Scale bar equals $2 \mathrm{~mm}$.

Description. Floral part $5.5 \mathrm{~mm}$ long and $0.7 \mathrm{~mm}$ wide. Apex attenuate; a midrib and thin lateral veins present.

Number of specimens examined. 1. UF15737059316.

Remarks. This specimen may represent a petal, a stipule, or a wing of a fruit/seed.

\section{Claiborne Floral Type 20}

(Figure 41)

Description. A mass of stamens laterally preserved. The size of the filament zone about $7 \mathrm{~mm}$ long and $3 \mathrm{~mm}$ wide and the size of the anther zone about $10 \mathrm{~mm}$ long and $1.5 \mathrm{~mm}$ wide; anthers suborbiculate, ca $0.8 \mathrm{~mm}$ long and $0.6 \mathrm{~mm}$ wide.

Number of specimens examined. 2. UF15737059209.

Remarks. This stamen mass is different from all other Claiborne reproductive material recognized.

\section{Angiosperm Incertae Sedis - Infructescences}

\section{"Sparganium" sp.}

(Figure 42)

v. 1930 Sparganium? sp., Berry, p. 54; pl. 8, fig. 1.

v. 2013 "Sparganium" sp. Wang, Blanchard, Dilcher, fig. 49.
Description. Globose infructescence ca $8.0 \mathrm{~mm}$ in diameter, bearing numerous fruits ca $0.5 \mathrm{~mm}$ in diameter. Stalk ca $6 \mathrm{~mm}$ long and 1 to $1.5 \mathrm{~mm}$ wide, covered with trichomes. Triangular projections ca $0.25 \mathrm{~mm}$ long present on each fruit.

Number of specimens examined. 1. UF15737027592.

Remarks. This specimen from the Bovay clay pit is the same as the two specimens from the Warman clay pit (Wang et al., 2013), except that it is larger.

\section{Claiborne Infructescence Type 4}

(Figure 43)

Description. Incomplete catkin ca $7 \mathrm{~cm}$ long and 5 $\mathrm{mm}$ wide; axis ca $1 \mathrm{~mm}$ wide. Florets/fruits sessile, ca $1.5 \mathrm{~mm}$ long and $0.7 \mathrm{~mm}$ wide, attached in the axils of bracts; three or four florets/fruits per centimeter. Subtending bract simple, ca $2.5 \mathrm{~mm}$ long, extending from the axis at a $45^{\circ}$ angle.

Number of specimens examined. 1. UF15737059313.

Remarks. The specimen is poorly preserved. However, this catkin can be distinguished from Eokachyra aeolius Crepet, Dilcher, and Potter, 1975 (see Wang et al., p. 24, figure 18) in that the bracts of $E$. aeolius are three to four lobed, and the florets are densely arranged on the axis. It differs from the 

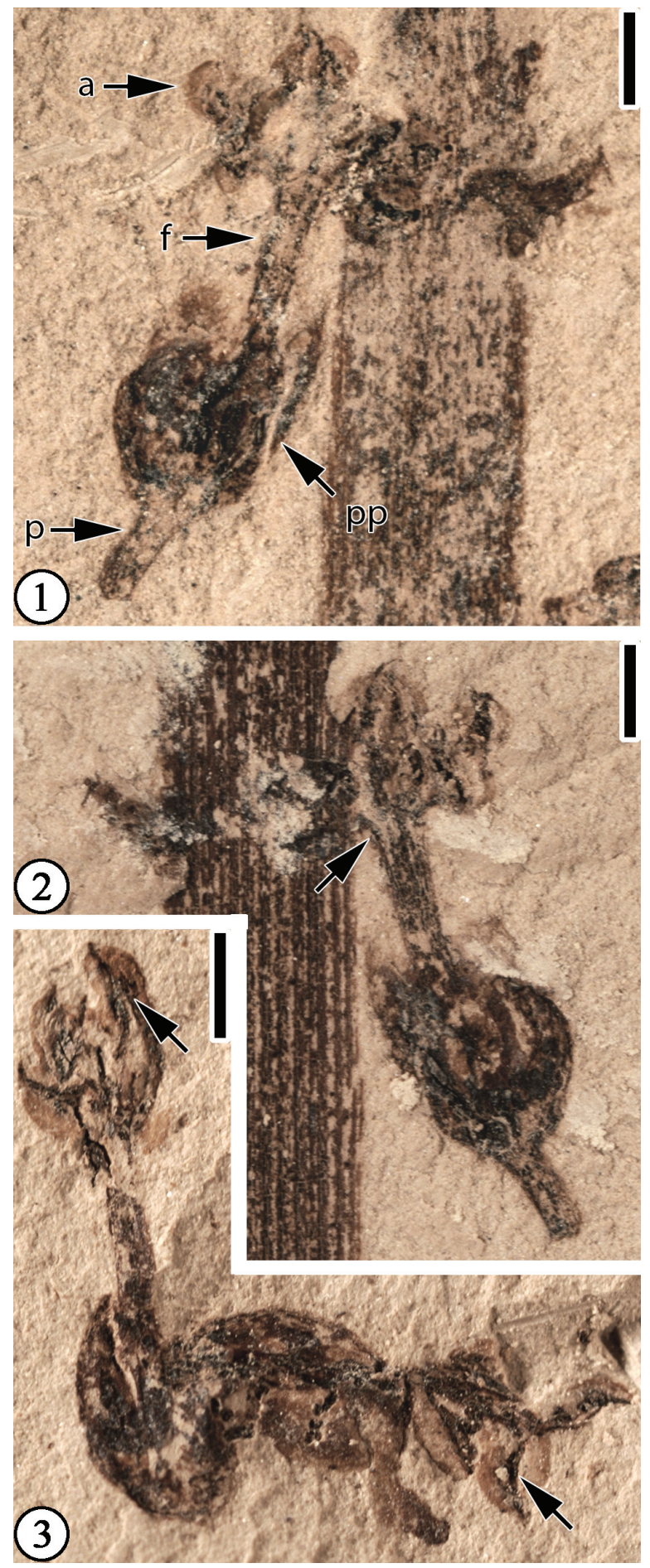

FIGURE 39. Claiborne Floral Type 18. All Scale bar equals $1 \mathrm{~mm}$ : 1) UF15737-059241'a. Counterpart of a laterally preserved flower showing a short pedicel $(p)$, fused filaments (f), anthers (a), and a perianth part (pp); 2) UF15737-059241a. Part of Figure 39.1 showing a filament spliting from the column (indicated by arrow); 3) UF15735-059323. Two laterally preserved flowers. Note strong connectives of the anthers (indicated by arrows).

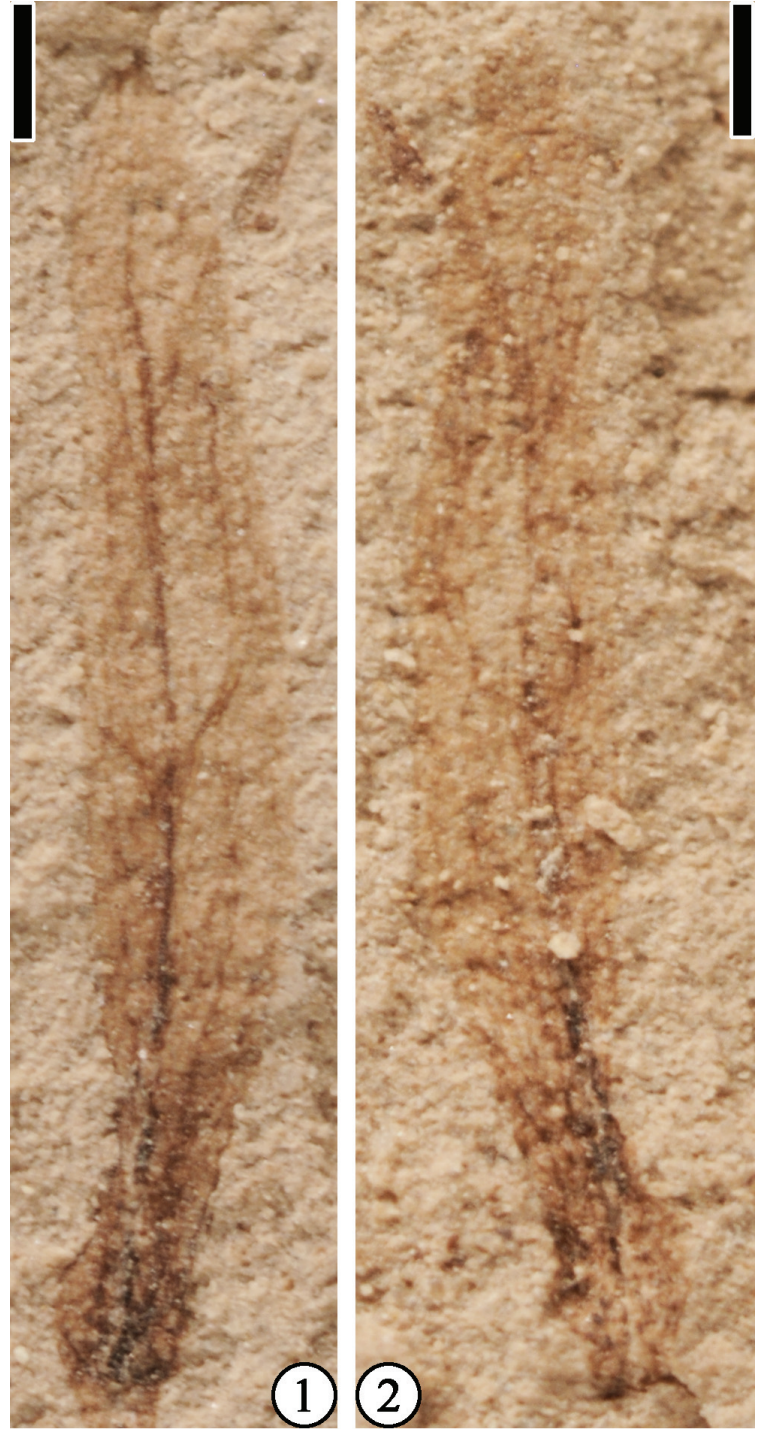

FIGURE 40. Claiborne Floral Type 19 (1-2), UF15737059316, 059316'. Part and counterpart of a specimen showing midvein and lateral veins. Scale bar equals 0.5 $\mathrm{mm}$.

catkin of Eomimosoidea plumosa Crepet and Dilcher, 1977 in that the bract subtending each flower of $E$. plumosa is auricular in shape (see Wang et al., 2013, p. 13, figure 10, 11). It differs from Trigonobalanoidea americana Crepet and Nixon, 1989 in that there are no bracts subtending the florets/fruits of $T$. americana (see Crepet and Nixon, 1989, p. 851; figure 28).

\section{Claiborne Infructescence Type 5 \\ (Figure 44)}

Description. Infructescence pedunculate, about 5 $\mathrm{mm}$ in diameter, bearing at least seven crescentshaped, winged fruits ca $2 \mathrm{~mm}$ long and $1 \mathrm{~mm}$ 

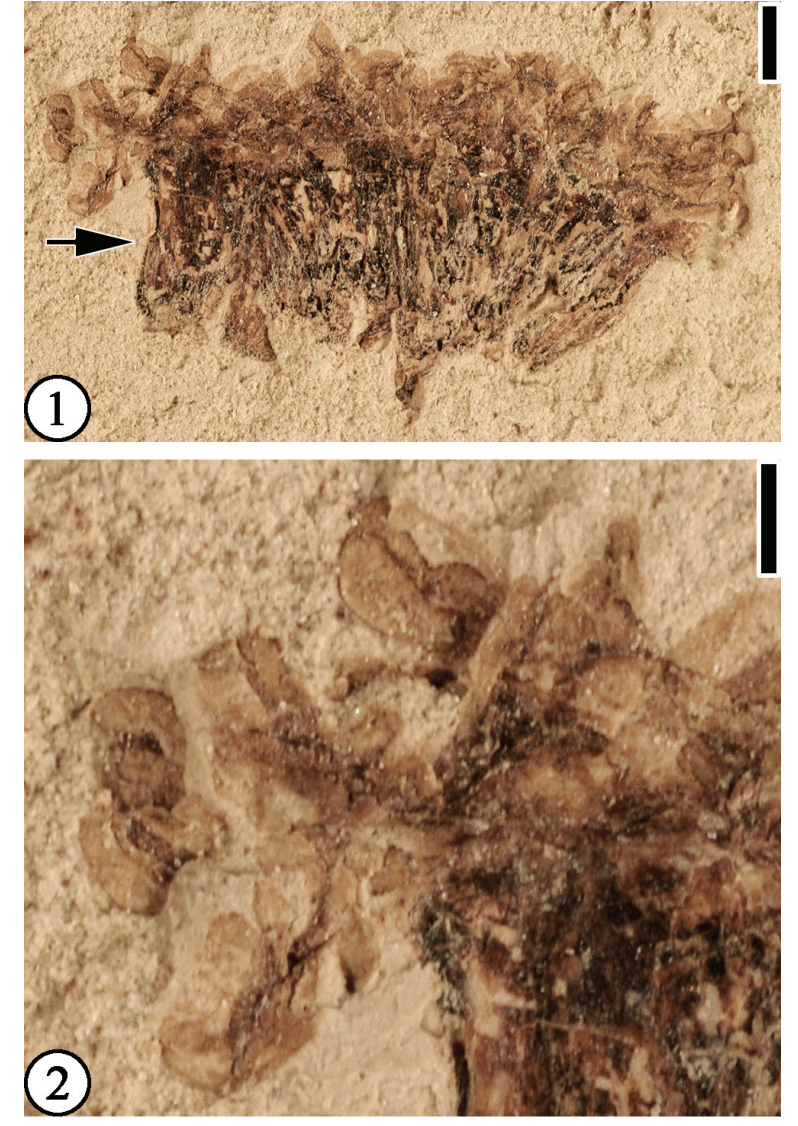

FIGURE 41. Claiborne Floral Type 20: 1) UF15737059209. Showing stamen mass. Note distinct filament zone (indicated by arrow) and anther zone above. Scale bar equals $1 \mathrm{~mm}$; 2) Enlargement of Figure 41.1 to show suborbiculate anthers. Scale bar equals 0.5 $\mathrm{mm}$.

wide. Receptacle $4 \mathrm{~mm}$ wide and $2 \mathrm{~mm}$ wide; peduncle $4 \mathrm{~mm}$ long and $0.5 \mathrm{~mm}$ wide.

Number of specimens examined. 2. UF15737059234, 059250.

Remarks. This small infructescence differs from all other infructescences described from the Claiborne Group in its small, winged fruits attached to a receptacle. The specimen illustrated in Figure 44.2 (UF15737-059234) may be an infructescence at a less mature stage.

\section{Claiborne Infructescence Type 6}

(Figure 45)

Description. Laterally compressed spherical infructescence, $6 \mathrm{~mm}$ in diameter. Peduncle incomplete, $5 \mathrm{~mm}$ long and $1 \mathrm{~mm}$ wide, covered with trichomes. Individual fruit about $1 \mathrm{~mm}$ in diameter, with persistent perianth parts; a depression present on each fruit.
Number of specimens examined. 1. UF15737059315.

Remarks. The number of fruits in each infructescence and the number of perianth parts associated with each fruit are unknown. The depression on each fruit probably indicates the presence of a pedicel. This infructescence type is different from Infructescence Type 1 from the Warman clay pit, Tennessee (Wang et al., 2013, figure 31) in having a spherical shape, smaller individual fruits, presence of persistent perianth parts, and the absence of spines on the peduncle.

\section{Claiborne Infructescence Type 7}

(Figure 46)

Description. Main axis $24 \mathrm{~mm}$ long and $0.5-1 \mathrm{~mm}$ wide, dichotomously branching once to give rise to two branches, each ca $12 \mathrm{~mm}$ long and $0.6 \mathrm{~mm}$ wide; each dichotomously branching once more to give rise to four ultimate axes, each bearing one aggregate globose fruit ca $3.5 \mathrm{~mm}$ in diameter. At least four seeds in each fruit, ca. $1-1.5 \mathrm{~mm}$ in diameter, attached at a central point.

Number of specimens examined. 1. UF15738060633.

Remarks. The specimen may represent a determinate infructescence such as a raceme. The two lateral branches may represent the pedicels of fruits.

\section{Angiosperm Incertae Sedis - Fruits and Seeds}

\section{Genus CARPOLITHUS Linnaeus, 1768 Carpolithus boldensis sp. nov.}

(Figure 47)

Description. Lemma narrowly elliptic, $6.5 \mathrm{~mm}$ long and $1.2 \mathrm{~mm}$ wide, a midvein extending from the base of the awn to the seed body; seed attached to the basal part of the lemma, narrowly elliptic, 3.5 $\mathrm{mm}$ long and $1.2 \mathrm{~mm}$ wide, apex rounded; awn 2 $\mathrm{mm}$ long and $0.1 \mathrm{~mm}$ wide, attached to the apex of the lemma.

Number of specimens examined. 2. UF15738059413 (Holotype, designated here); UF15738011030'b.

Remarks. This disseminule probably represents a monocot (grass) fruit. Coincidentally, a fragment of a monocot leaf is preserved next to the disseminule on the same specimen. Spikelets and inflorescence fragments with in situ pollen that have a suite of diagnostic characters of Poaceae have been reported from the Claiborne Group from western Tennessee (Crepet and Feldman, 1991).

Genus SAPORTASPERMUM Meyer and Manchester, 1997 

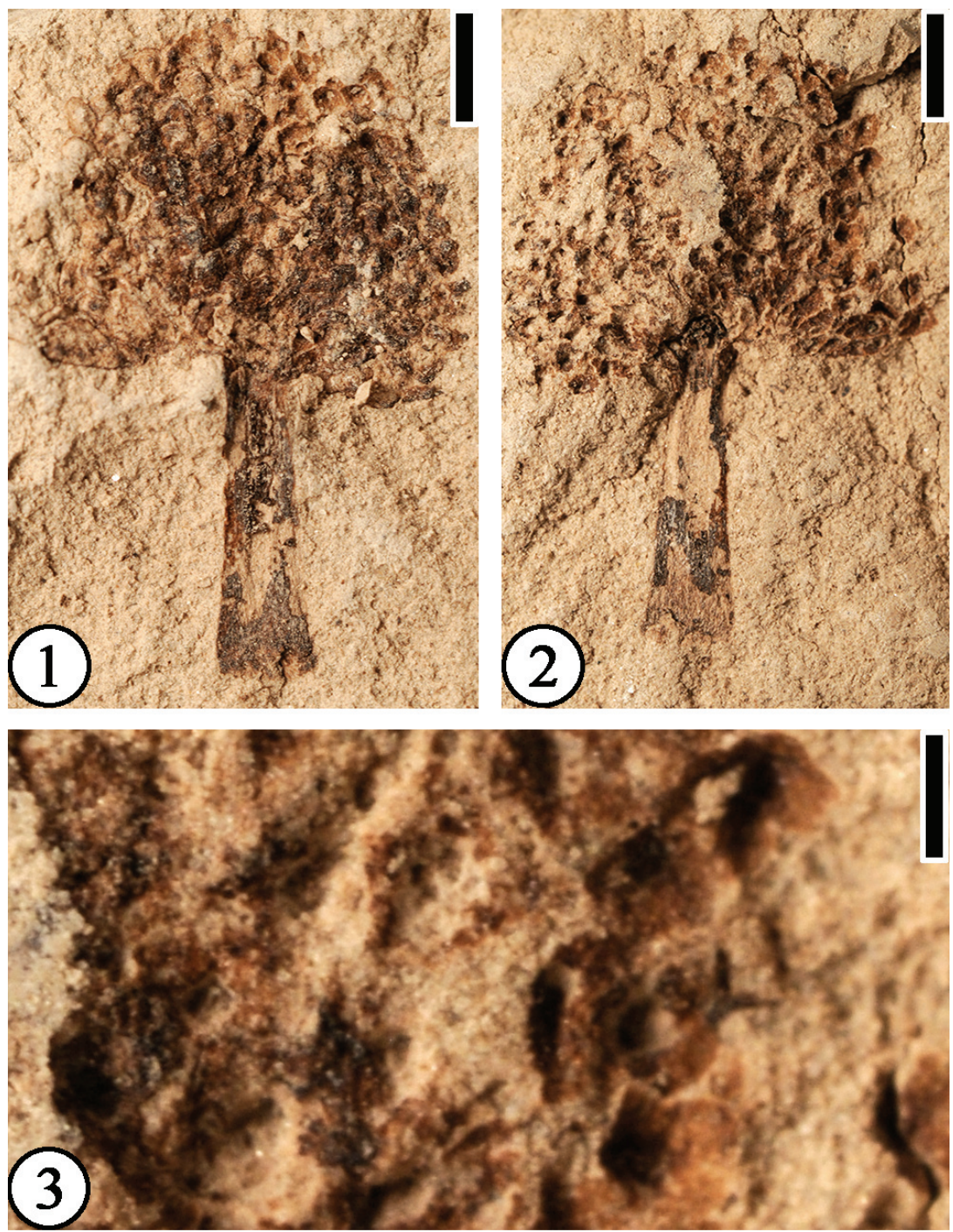

FIGURE 42. "Sparganium" sp. : 1-2). UF15737-027592. 027592'. Part and counterpart of a specimen showing an infructescence with a stout stalk. Scale bar equals $2 \mathrm{~mm}$; 3 ) Enlargement of Figure 42.2 to show small fruits. Scale bar equals $0.5 \mathrm{~mm}$.

Type species. Saportaspermum occidentalis Meyer and Manchester, 1997, here designated.

\section{cf. Saportaspermum sp.}

(Figure 48)

Description. Seed $2.2 \mathrm{~cm}$ long; wing $5 \mathrm{~mm}$ wide just above the seed and gradually narrowing toward the apex, with a few longitudinal striations. Seed body large relative to wing, $7 \mathrm{~mm}$ in diameter with radial striations.

Number of specimens examined. 1. UF15737059314.

Remarks. Saportaspermum is a fossil genus established by Meyer and Manchester (1997) (p. 161-162, pl. 74, figures 14-20) for winged seeds with uncertain affinities from the Oligocene Bridge
Creek flora. These seeds consist of an ovate to elliptical seed body that is oriented with the long axis at an oblique $\left(40^{\circ}\right)$ angle to the long axis of the veinless wing.

This single specimen from the Bovay locality possesses similar characters. However, the seed body possesses radial striations, and its shape is different from and its size is larger than other known Saportaspermum species (Meyer and Manchester, 1997; Collinson et al., 2010, 2012; Kvaček and Wilde, 2010).

"Acer" knowltoni (Berry) Brown, 1940

(Figure 49)

v. 1930 Phanerophlebites knowltoni Berry, page, 50, pl. 7, fig. 6 . 


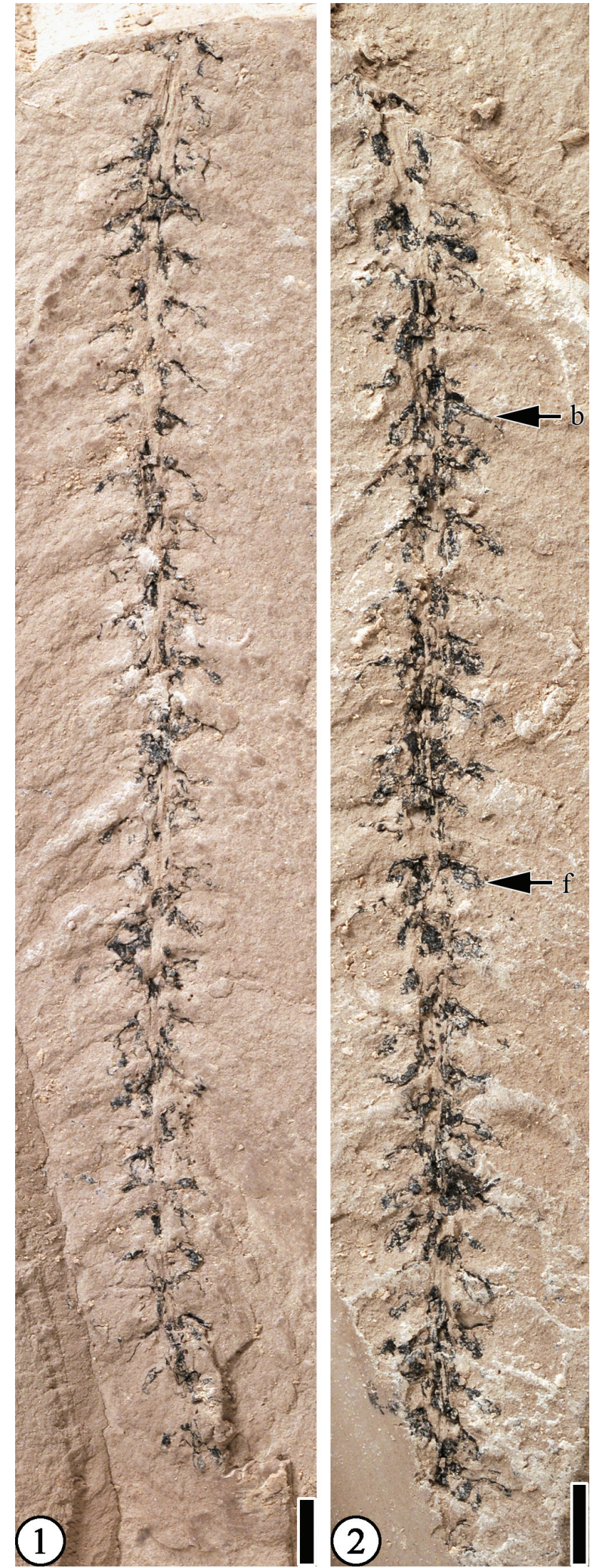

FIGURE 43. Claiborne Infructescence Type 4 (1-2), UF15737-059313, 059313'. Part and counterpart of specimen showing an infructescence with sessile fruits (f) attached to the axils of bracts (b). Scale bar equals 3 $\mathrm{mm}$.
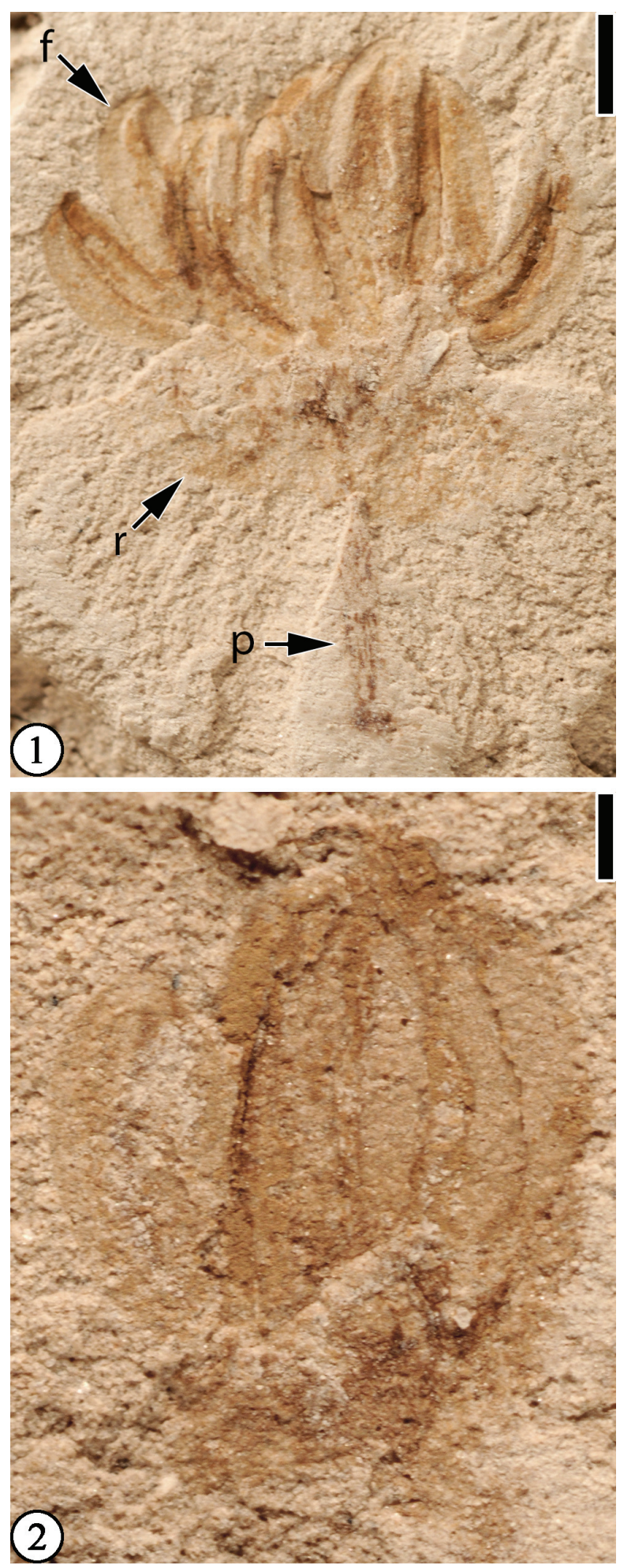

FIGURE 44. Claiborne Infructescence Type 5: 1) UF15737-059250. An infructescence with seven winged fruits (f), a receptacle (r), and a peduncle (p). Scale bar equals $1 \mathrm{~mm}$; 2) UF15737-059234. Showing an infructescence with at least five fruits. Scale bar equals $0.5 \mathrm{~mm}$. 


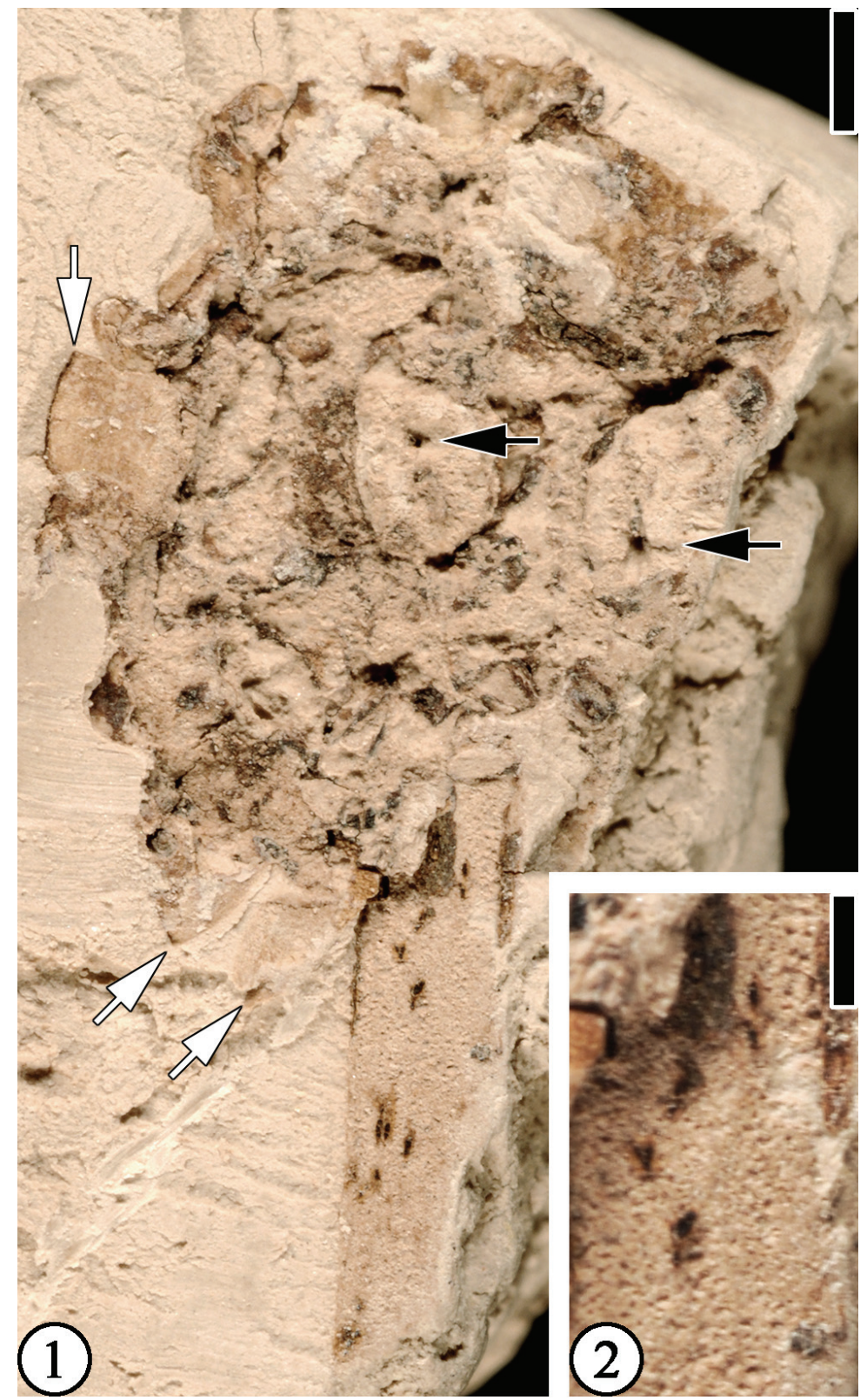

FIGURE 45. Claiborne Infructescence Type 6: 1) UF15737-059315. Showing laterally compressed infructescence with an incomplete peduncle. Note the presence of persistent perianth parts (indicated by white arrows) and pedicels on individual fruit (indicated by black arrows). Scale bar equals $1 \mathrm{~mm}$; 2) Enlargement of Figure 45.1 to show trichome bases on peduncle. Scale bar equals $0.5 \mathrm{~mm}$.

v. 1940 "Acer" knowltoni (Berry) Brown; Brown, p. 351 , figs. 7,8 .

Description. Samara $2.5 \mathrm{~cm}$ long and $1 \mathrm{~cm}$ at the widest part of wing. Wing rounded at apex, gradually narrowing toward the seed. Outer margin straight; inner margin straight at the proximal $67 \%$ and wavy at the distal $33 \%$. Veins fine, numerous, diverging from the distal portion of the seed body. A protrusion ca $2 \mathrm{~mm}$ long with a fibrous tip present on one specimen.
Number of specimens examined. 2. UF15737059223 and an unnumbered specimen from Bolden locality, stored at the Field Museum of Natural History.

Remarks. Berry (1930, p. 48, plate 7, figure 6) first reported a fruit from the Holly Springs sand, Fayette County, Tennessee. He described it as a fragment of a pinna. Brown (1940, p. 351; figures 7, 8) transferred this specimen and two leaves, described by Berry (1930, p. 98, plate 21, figure 7; 


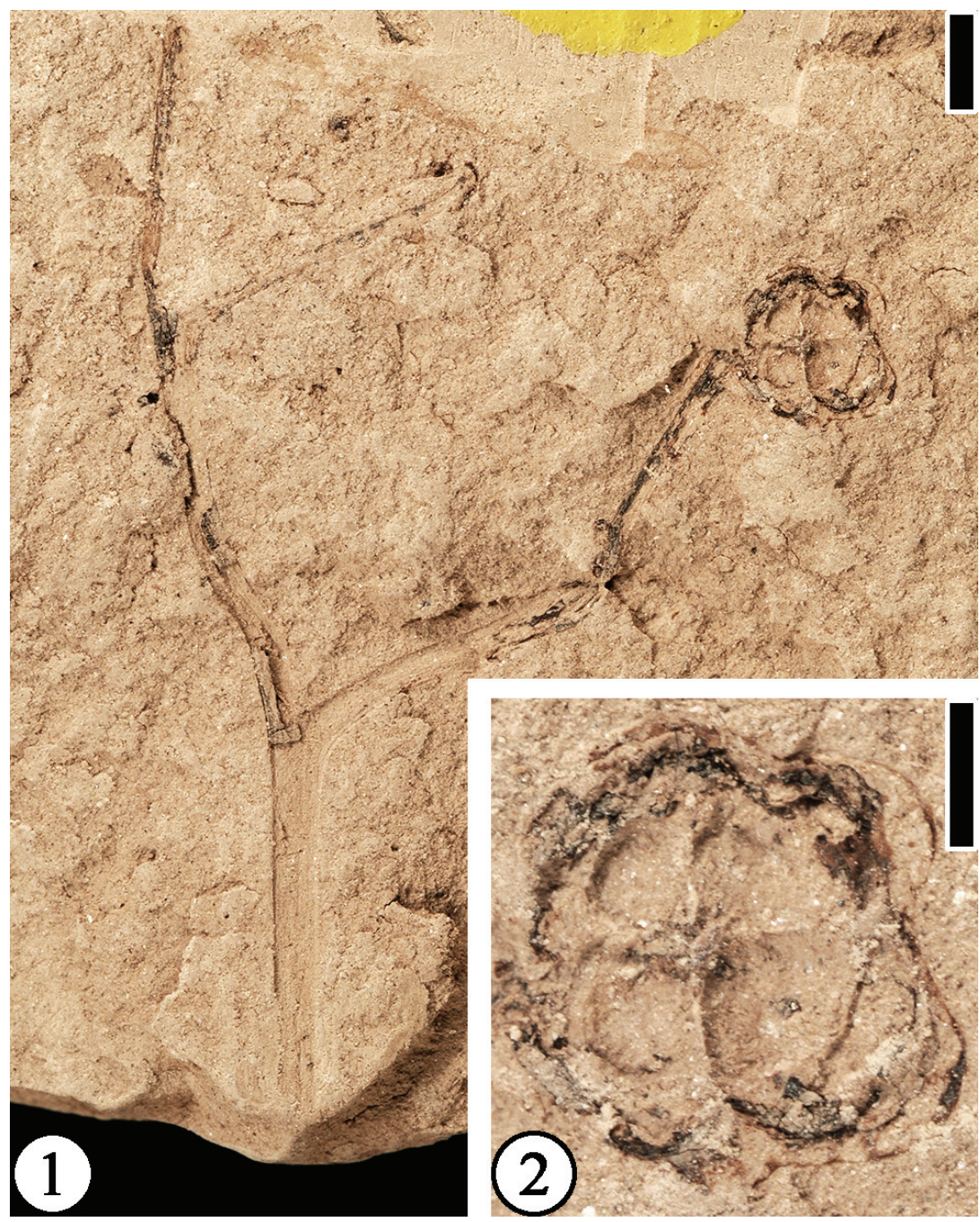

FIGURE 46. Claiborne Infructescence Type 8: 1) UF15738-060633. Showing a main axis with two lateral branches and a fruit. Scale bar equals $2 \mathrm{~mm}$; 2) Enlargement of Figure 46.1 showing impressions of at least 4 seeds attached to a central point. Scale bar equals $1 \mathrm{~mm}$.

plate 42, figure 7) as Negundo knowltoni, to Acer knowltoni. The transfer of the fruit out of the fossil fern genus Phanerophlebites is valid. However, the transfer of the leaf specimens is invalid because these leaves and fruits are not attached. Also, assigning these fruits to the genus Acer is probably incorrect, because, as stated by Brown (1940), "the samaras have unusually long wings, and narrow heads which are seldom well enough preserved to show the attachment scar." Even though the specimens are well preserved (Figure 49.1-4), they do not appear to have the typical attachment scars that are often observed on fossil Acer fruits. In this report, we place these fruits in Angiosperm Incertae Sedis.

The venation pattern of the fruit is similar to that of extant fruits of Banisteriopsis (Malpighia- ceae; Burnham, 1995), Securidaca (Polygalaceae; Burnham, 1995; Pigg et al., 2008) and Paleosecuridaca curtisii (Polygalaceae; Pigg et al., 2008), Tipuana (Legumnosae; Burnham, 1995), Loxopterygium (Anacardiaceae; Burnham and Carranco, 2004) and Deviacer (Manchester, 1994; Chen and Manchester, 2015). However, the lack of detailed information of the seed and a stalk make it difficult to further compare this fruit with the modern and other fossil taxa.

\section{Claiborne Fruit/Seed Type 6}

(Figure 50)

Description. Fruit/seed nearly spherical in outline, $0.9-1.2 \mathrm{~cm}$ in diameter. Surface with reticulate pattern, Fibers present on the fruit/seed surface. 

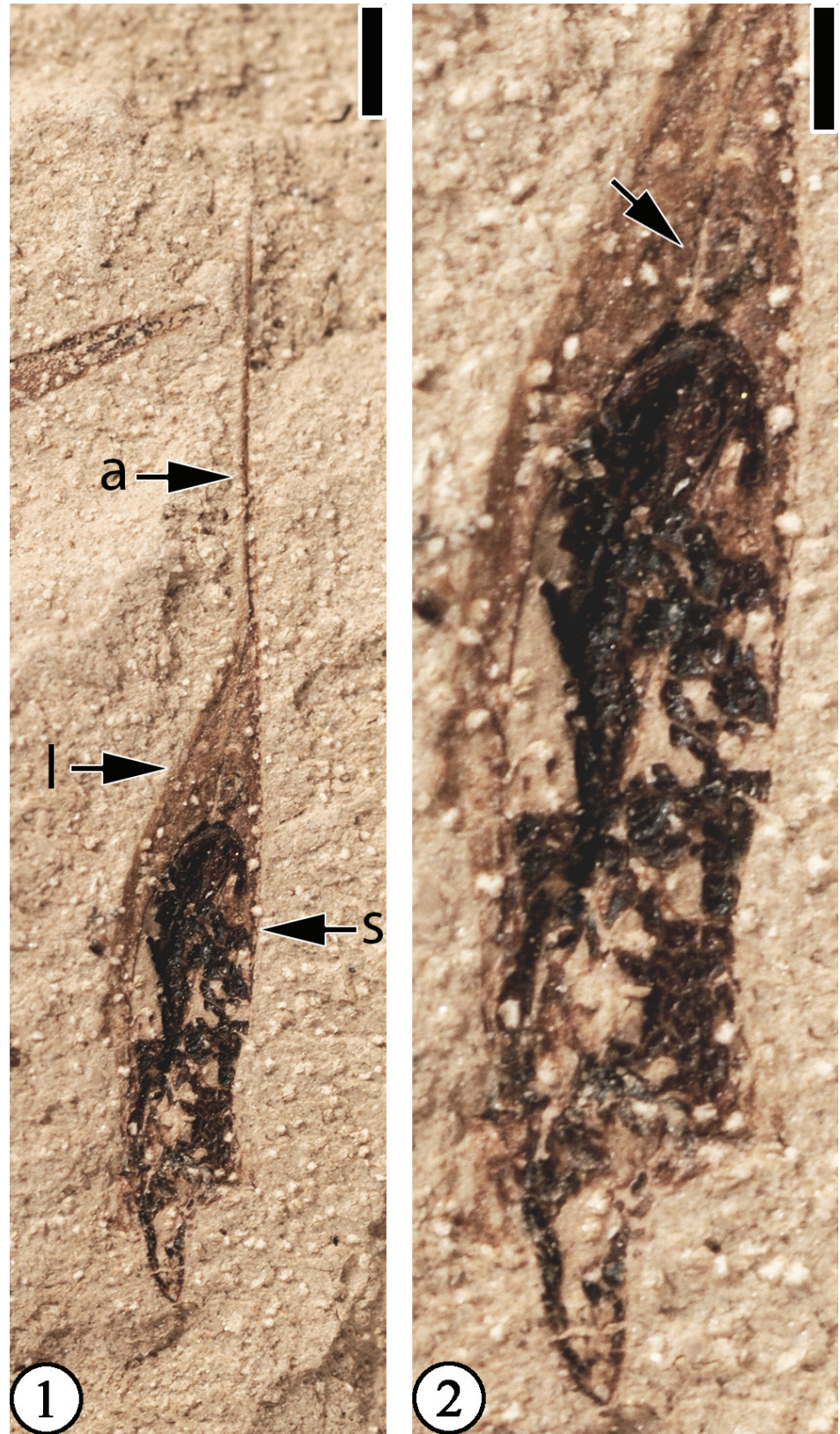

FIGURE 47. Carpolithus boldensis sp. nov.: 1) UF15738-059413. Specimen showing lemma (I), awn (a), and seed body (s). Scale bar equals $1 \mathrm{~mm}$; 2) Enlargement of Figure 47.1 to show midvein of lemma (indicated by arrow) and narrow, elliptic seed body. Sclae bar $=0.5 \mathrm{~mm}$.

Number of specimens examined. 2. UF15737059237, 059242.

Remarks. The outline of this fruit/seed type is similar to those Leguminosites chesterensis Berry specimens from Holly Springs sand, Tennessee, described by Berry $(1930$, p. 89 , plate 14 , figures 7-10). However, they differ in that specimens from the Bovay locality possess fiber strands.

Claiborne Fruit/Seed type 7

(Figure 51)
Description. Disseminule spatulate, $5.5 \mathrm{~mm}$ long and ca $1.5 \mathrm{~mm}$ wide at the broadest end and tapering to $0.5 \mathrm{~mm}$ at the other. Margin entire. No surface pattern or ornamentation.

Number of specimens examined. 1. UF15837059319.

Remarks. This disseminule is similar to the fruits of Anisosciadium lanatum Boissier 1888, of the Apicaceae. However, only one specimen is observed 


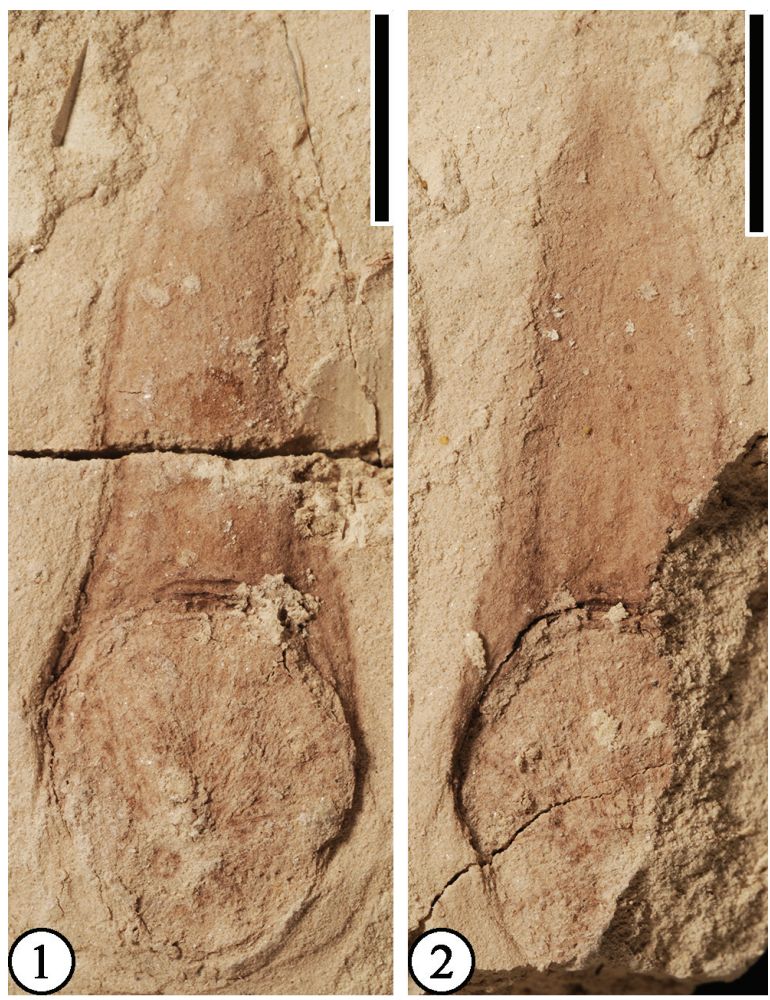

FIGURE 48. cf. Saportaspermum sp. (1-2), UF15737059314, 059314'. Part and counterpart of specimen showing circular seed body and veinless wing. Note radial striations on the seed body. Scale bar equals 5 $\mathrm{mm}$.

from this locality. There are not enough diagnostic characters to assess its modern affinities.

\section{Claiborne Fruit/Seed Type 8}

(Figure 52)

Description. Compressed ovoid sclerotesta, surface smooth, $5.5 \mathrm{~mm}$ long and $3 \mathrm{~mm}$ wide; endotesta membranous.

Number of specimens examined. 1. UF15737059245.

Remarks. In gross morphology, this type is similar to the seeds of cf. Magnolia sp. (Wang et al., 2013, p. 9, figure 5) and Corylopsis grotei (Wang et al., 2013 , p. 11, figure 8 ), both described from the Warman clay pit. However, characters at the chalazal end of the seed are not visible, and this makes it difficult to assign to either taxon.

\section{Claiborne Fruit/Seed Type 9}

(Figure 53)

Description. Elliptical fruit/seed $9 \mathrm{~mm}$ long and 3.5 $\mathrm{mm}$ wide at widest point. Tapering at both ends. Longitudinal striations visible.

Number of specimens examined. 1. UF15737059324.
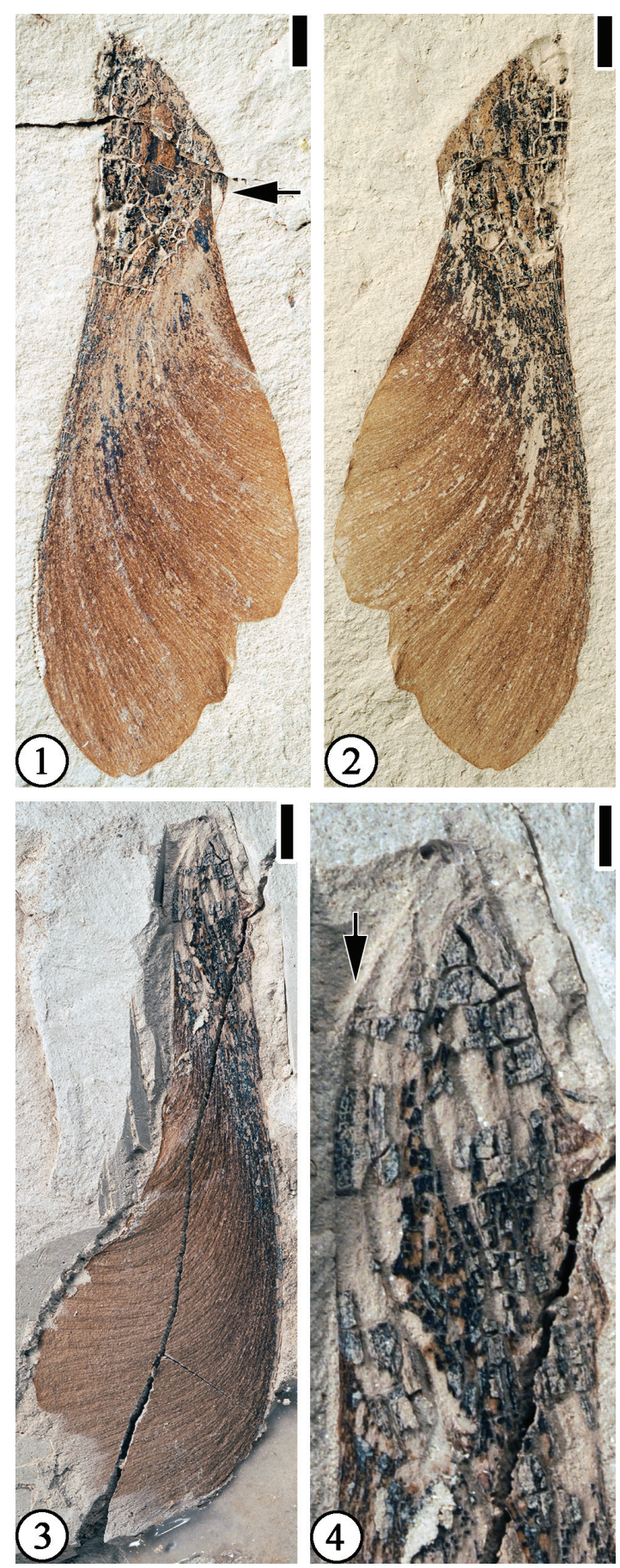

FIGURE 49. "Acer" knowltoni (Berry) Brown, 1940: 1-2) UF15737-059223, 059223'. Part and counterpart showing a samara. Note the protrusion with fibrous tip (indicated by arrow). Scale bar equals $2 \mathrm{~mm}$; 3 ) A specimen from the Bolden clay pit, stored at the Paleobotany Collection at the Field Museum of Natural History, showing a samara and its venation. Scale bar equals $3 \mathrm{~mm}$; 4 ) Enlargement of Figure 49.3 to show the smooth curvature of the inner margin of the base of the samara (indicated by arrow) and the seed outline. Scale bar equals $1 \mathrm{~mm}$. 



FIGURE 50. Claiborne Fruit/Seed Type 6: 1-2) UF15737-059237, 059237'. Part and counterpart of a specimen showing a spherical fruit/seed. Note fibers on the surface (indicated by arrows). Scale bar equals $1 \mathrm{~mm} ; 3$ ) UF15737-059242. Showing a spherical fruit/seed. Scale bar equals $1 \mathrm{~mm}$; 4) Enlargement of Figure 50.3 (indicated by arrow) to show fibers associated with the fruit/seed. Scale bar equals $0.5 \mathrm{~mm}$; 5) Enlargement of Figure 50.2 (indicated by arrow) to show fibers associated with the fruit/seed. Scale bar equals $0.5 \mathrm{~mm}$. 

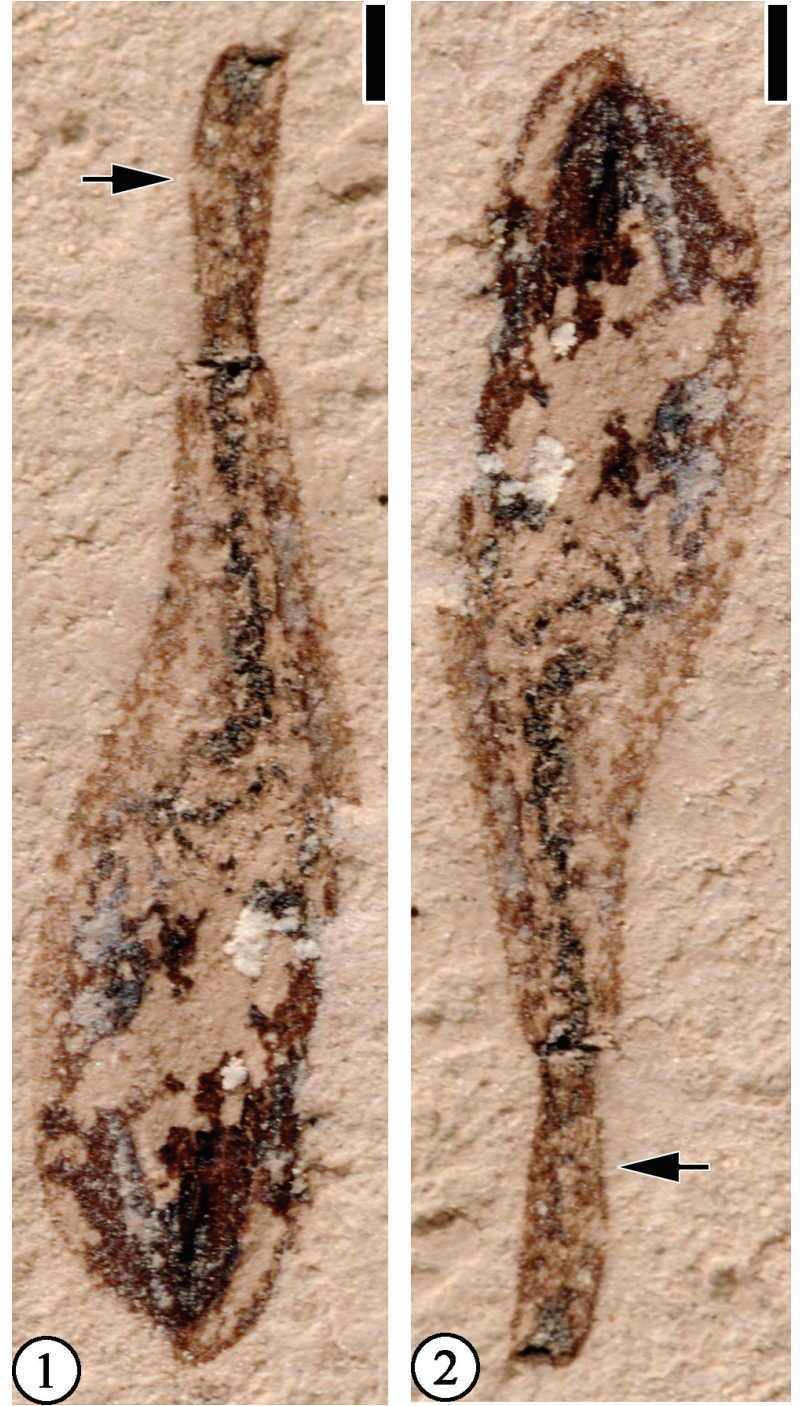

FIGURE 51. Claiborne Fruit/Seed Type 7 (1-2), UF15837-059319. Showing two possible orientations of a disseminule. It may represent a fruit with a persistent style (indicated by arrow) as in Figure 51.1 or a fruit with a pedicel (indicated by arrow) in Figure 51.2. Scale bar equals $0.5 \mathrm{~mm}$.

Remarks. The longtitudinal striations and the shape are similar to those of "Aralia" semina Berry (see Wang et al., 2013, p. 36-37, figure 30). But the size of "Aralia" semina seeds is only about $25 \%$ of Fruit/Seed Type 9. It is possible that this specimen may represent a beetle elytra. However, the presence of a thin layer of cuticle (Figure 53.2; UF15737-059324') makes it more likely to be a compressed fruit/seed.

Claiborne Fruit/Seed Type 10

(Figure 54)

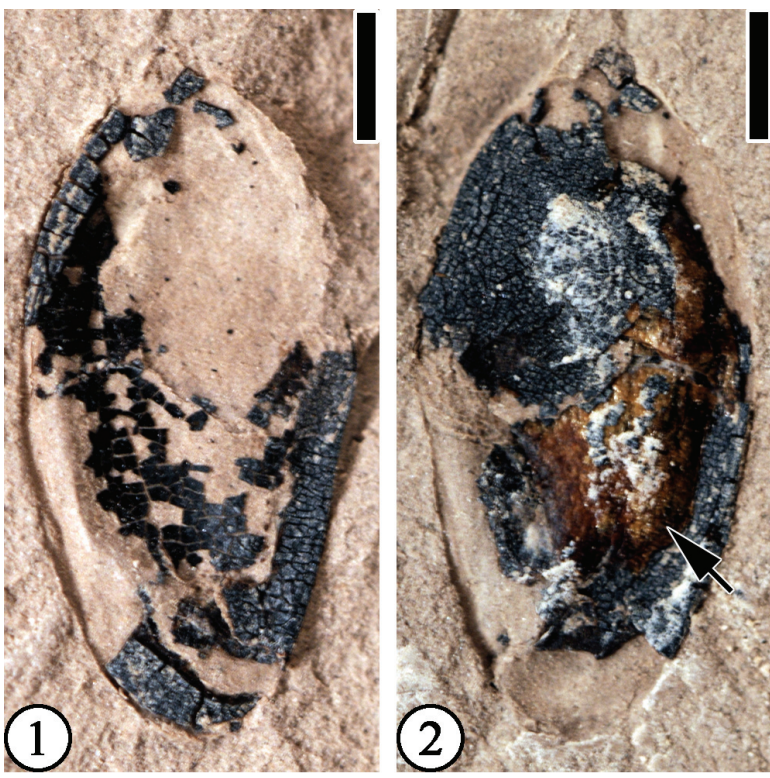

FIGURE 52. Claiborne Fruit/Seed Type 8 (1-2), UF15737-059245, 059245'. Part and counterpart of a specimen showing compressed ovoid sclerotesta with smooth surface and membranous endotesta (indicated by arrow in Figure 52.2). Scale bar equals $1 \mathrm{~mm}$.
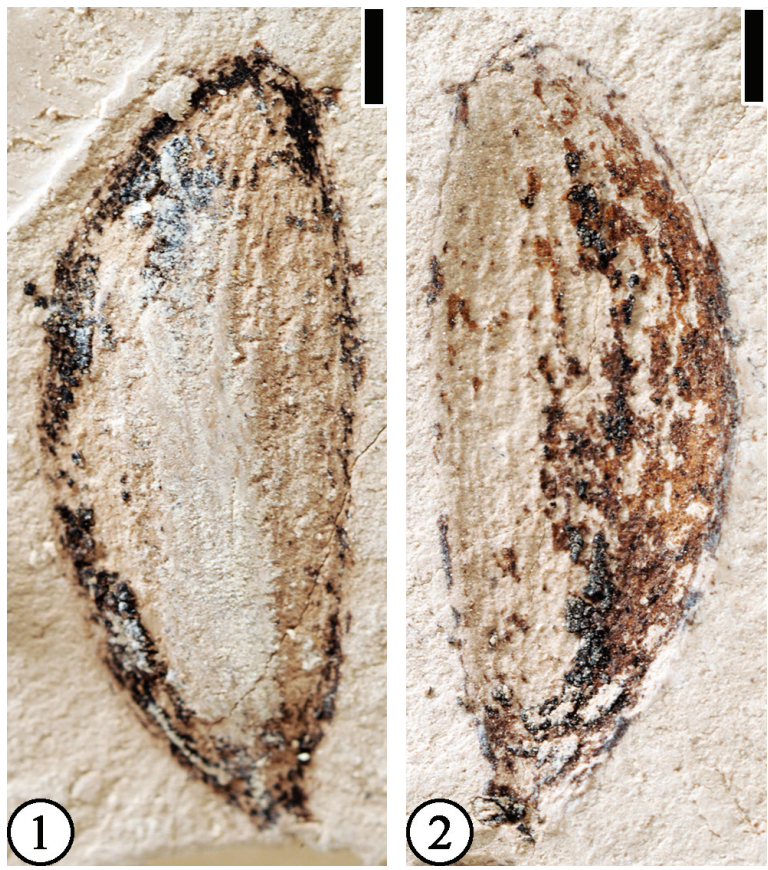

FIGURE 53. Claiborne Fruit/Seed Type 9 (1-2), UF15737-059324, 059324'. Part and counterpart of a specimen showing elliptical fruit/seed with longitudinal striations. Scale bar equals $1 \mathrm{~mm}$. 

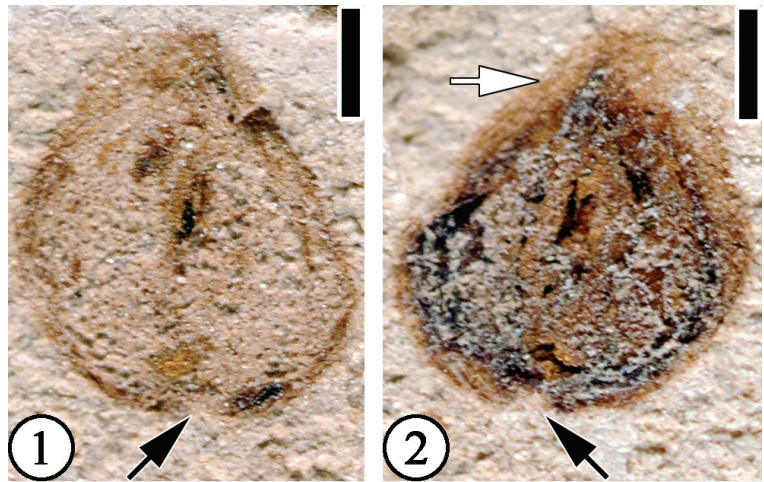

FIGURE 54. Claiborne Fruit/Seed Type 10 (1-2), UF15737-059228, 059228'. Part and counterpart of a specimen showing thin layer of tissue (indicated by white arrow) and hilum scar (at the bottom of seed as indicated by black arrows). Scale bar equals $0.5 \mathrm{~mm}$.

Description. Seed ca $2 \mathrm{~mm}$ in diameter. A thin layer of tissue up to $0.3 \mathrm{~mm}$ wide present on the periphery of the seed body.

Number of specimens examined. 1. UF15737059228.

Remarks. The thin layer of tissue around the seed body indicates that this specimen may represent a tiny winged seed.

Genus PALMOCARPON Berry, 1930

Palmocarpon wilcoxiana (Berry)

Wang, Blanchard, and Dilcher, 2013

(Figure 55)

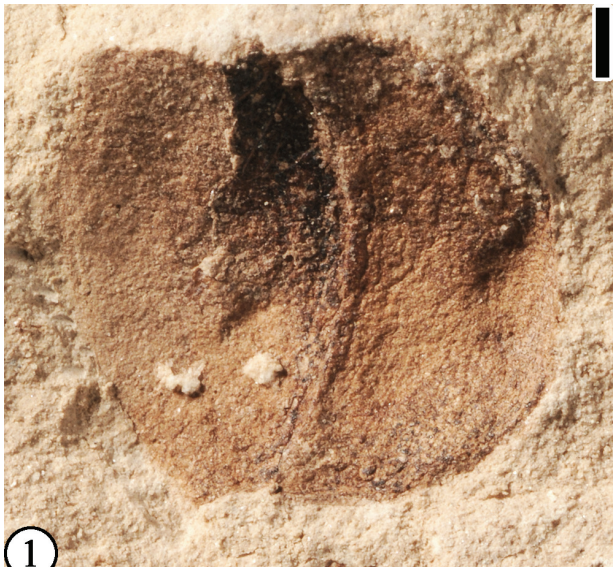

(1)

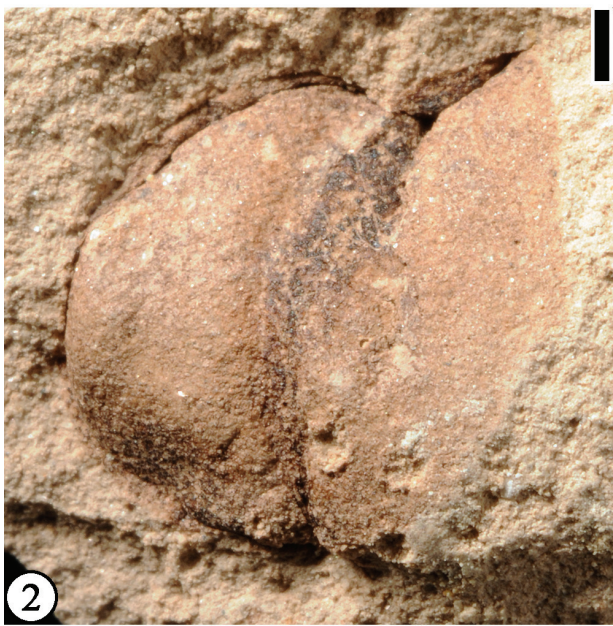

FIGURE 56. Claiborne Undetermined Structure 1 (1-2), UF15737-059229, 059229'. Specimen showing a median ridge on part and a median groove on the counterpart. Scale bar equals $1 \mathrm{~mm}$.
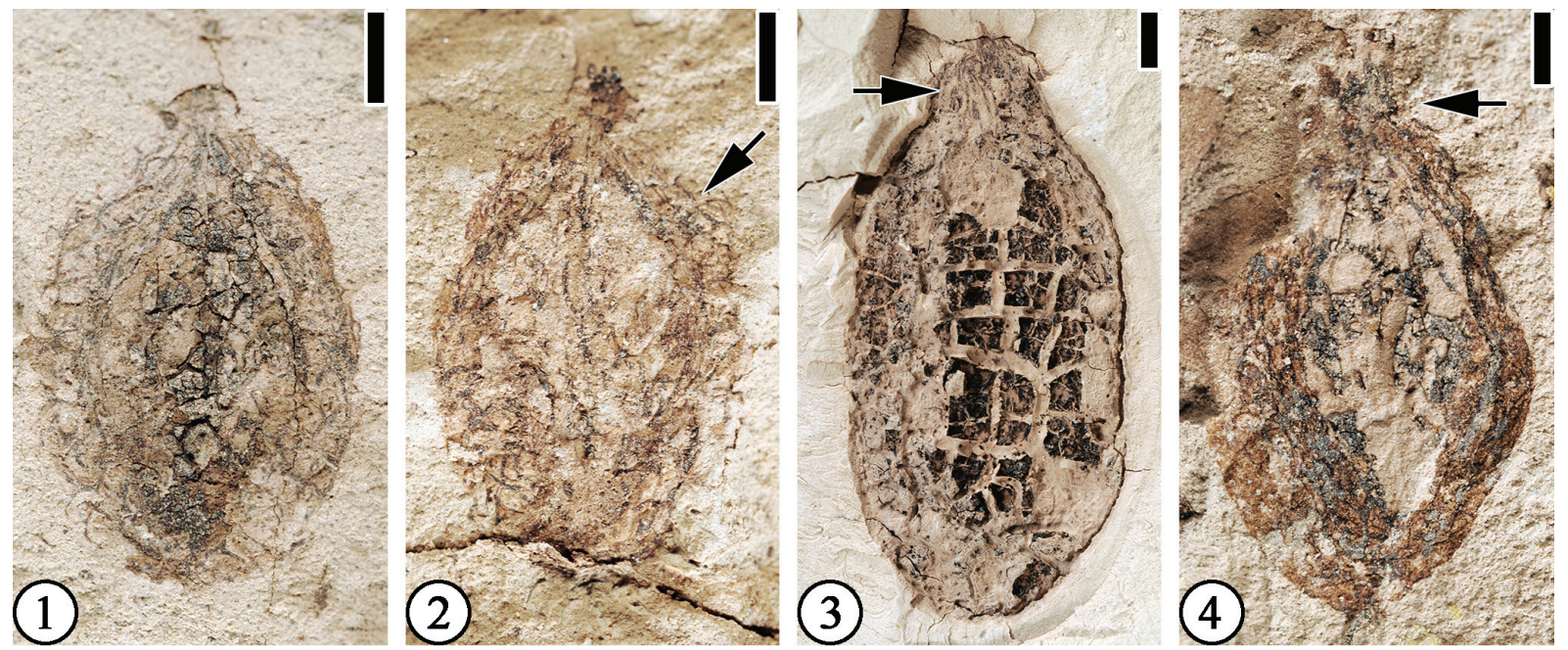

FIGURE 55. Palmocarpon wilcoxiana (Berry) Wang et al., 2013: 1-2) UF15737-008221, 008221'. Part and counterpart of a specimen showing elliptic endocarp and fiber strands (indicated by arrow). Scale bar equals $2 \mathrm{~mm}$; 3 ) UF15737-059231. Specimen showing elliptic endocarp. Note fine fiber strands at the distal end (indicated by arrow). Scale bar equals $2 \mathrm{~mm}$; 4) UF15737-059243a. Specimen showing fiber strands/projections at the distal end (indicated by arrow). Scale bar equals $2 \mathrm{~mm}$. 


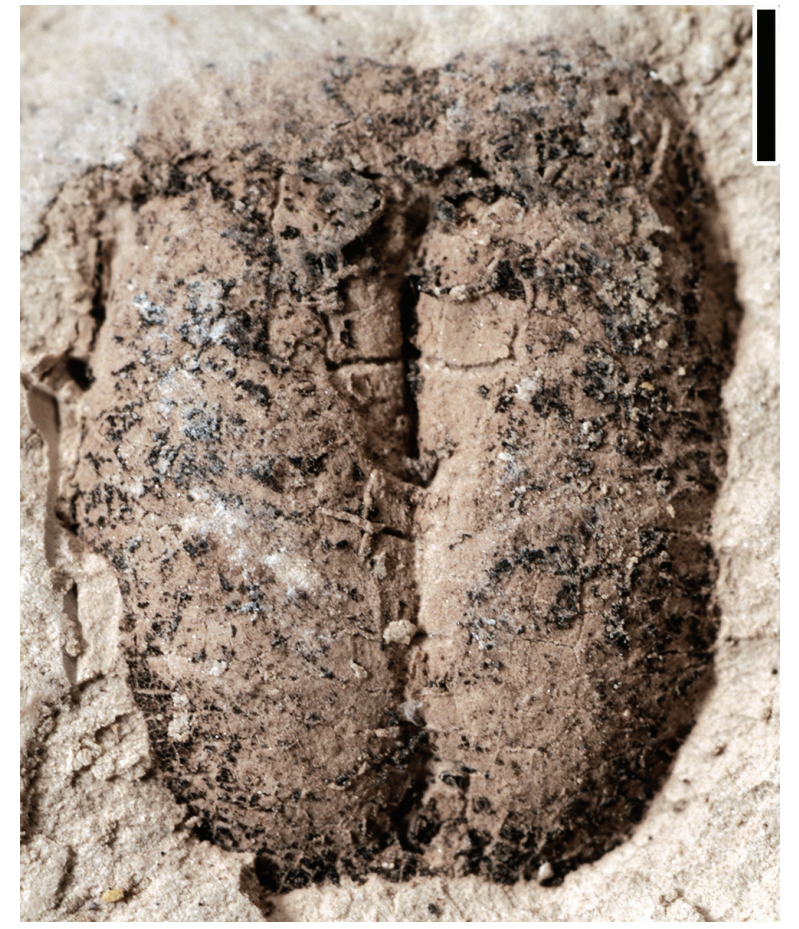

FIGURE 57. Claiborne Undetermined Structure 2, UF15737-059297. Specimen showing a symmetric structure with a central groove. Scale bar equals $2 \mathrm{~mm}$.

Description. Endocarp elliptic, $1.2-2.3 \mathrm{~cm}$ long and $0.7-1 \mathrm{~cm}$ wide. Distal fine projections $1-2 \mathrm{~mm}$ long.

Number of specimens examined. 3. UF15737008221, 059231, 059243a.

Remarks. This type of endocarp is common in the Claiborne Group (see Wang et al., 2013, p. 54-55, figures 47,48$)$.

\section{Undetermined}

\section{Claiborne Undetermined Structure 1}

(Figure 56)

Description. Structure $8 \mathrm{~mm}$ long and $7 \mathrm{~mm}$ wide with a curved, median groove/ridge. Broadest at the base. No ornamentation observed.

Number of specimens examined. 1. UF15737059229.

Remarks. This structure may represent one valve of a capsule, a bud scale, or a sepal of a flower. However, none of the known fruit capsules or flowers from the Claiborne Group seems to possess valves or sepals with similar morphology.

The median groove/ridge is similar to that of Carpolithus sophorites from the Warman clay pit (Wang et al., 2013, p. 51, figure 44). This specimen from Bovay differs from $C$. sophorites in having a rough surface, probably representing an internal

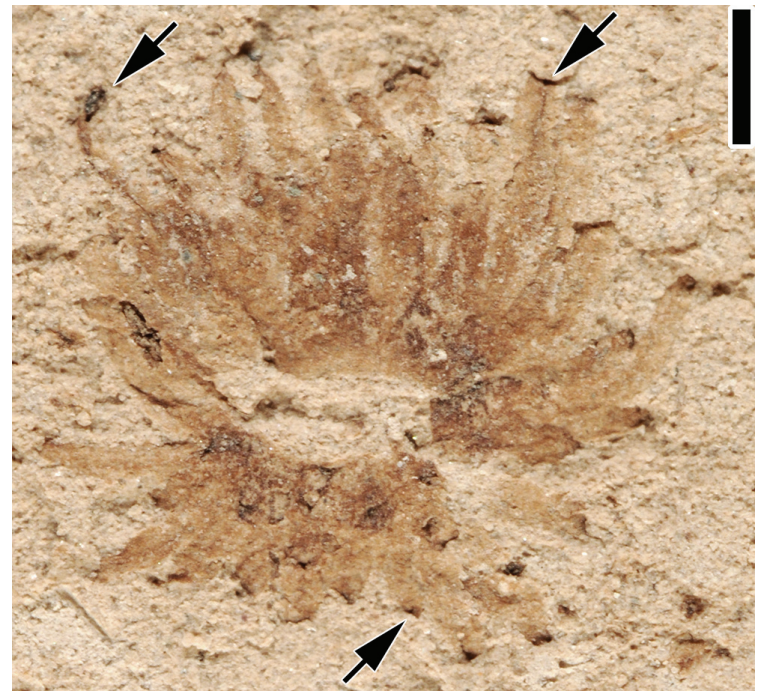

FIGURE 58. Claiborne Undetermined Structure 3, UF15737-059244. Specimen showing linear, basally fused units encircling a central area. Note that the apices of the linear units (indicated by arrows) are curved into the matrix. Scale bar equals $1 \mathrm{~mm}$.

mold of a seed. It is similar to Carpolithus puryearensis (Berry 1916b, p. 351, plate 104, figure 8 ) in that both have central grooves/ridges. They differ in that $C$. puryearensis is larger $(15 \mathrm{~mm}$ long and 8 $\mathrm{mm}$ wide), and its central groove/ridge is thin relative to the width of the entire structure.

\section{Claiborne Undetermined Structure 2 (Figure 57)}

Description. Structure rectangular in outline, 12 $\mathrm{mm}$ long and $9 \mathrm{~mm}$ wide with a lengthwise central groove dividing it into symmetrical portions.

Number of specimens examined. 1. UF15737059297.

Remarks. This structure differs from Undetermined Structure 1 and Carpolithus sophorites from the Warman clay pit (Wang et al., 2013, p. 51, figure 44) in that it is larger and the groove is straight.

\section{Claiborne Undetermined Structure 3 \\ (Figure 58)}

Description. Structure with about 24 linear, basally fused units encircling a central area approximately $1 \mathrm{~mm}$ in diameter; each unit ca $2 \mathrm{~mm}$ long and 0.3 $\mathrm{mm}$ wide, with an acute, curved apex.

Number of specimens examined. 1. UF15737059244.

Remarks. This structure may represent a basally fused calyx or a stem sheath on the node of Equisetum. 


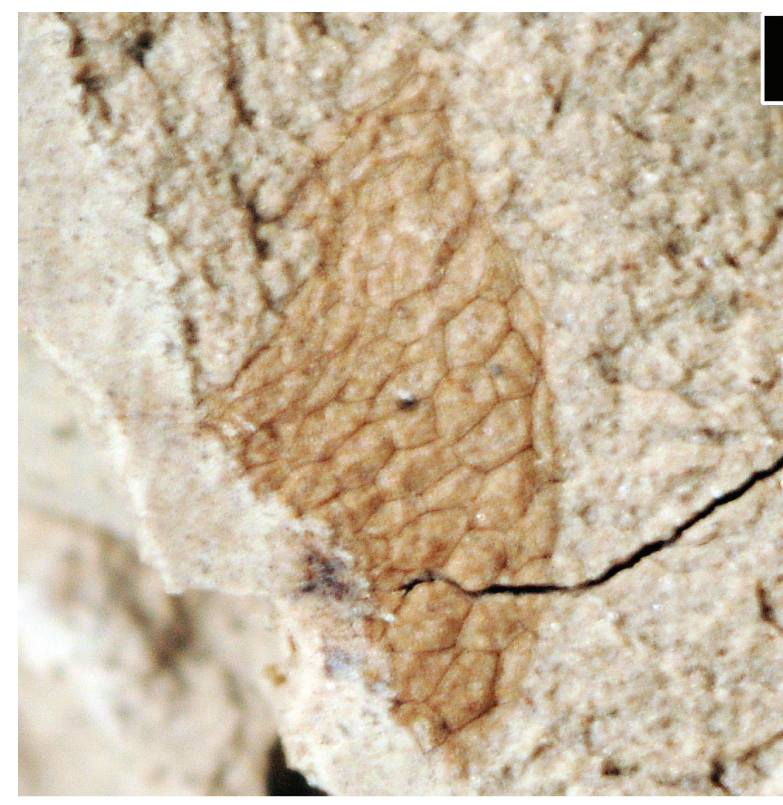

FIGURE 59. Claiborne Undetermined Structure 4, UF15737-008228. Specimen showing scale-like, irregular hexagonal surface pattern of the structure. Scale bar equals $0.25 \mathrm{~mm}$.

\section{Claiborne Undetermined Structure 4}

(Figure 59)

Description. Fragment of structure $2 \mathrm{~mm}$ long and $1 \mathrm{~mm}$ wide, with scale-like, irregular hexagonal surface pattern.

Number of specimens examined. 1. UF15737008228.

Remarks. The hexagonal surface pattern of the specimen is similar to that of the seed wing of some members of the Rubiaceae, e.g., Pinckneya bracteata (W. Bartram) Rafinesque, 1827. Fossils of the Rubiaceae have been reported from as early as the middle Eocene of Oregon and Washington, USA and Hainan, China, and the late Eocene of Panama and Australia (Graham, 2009; Shi et al., 2012). Leaves assigned to the Rubiaceae have also been reported from the Claiborne Group from Tennessee (Roth and Dilcher, 1979).

\section{DISCUSSION}

\section{Floristic Composition of the Bovay and Bolden Localities}

Of the 52 reproductive taxa/morphotypes recognized from the Bovay and Bolden localities (Table 1), Mississippi, 17 are identified to 11 extant families. These taxa/morphotypes include: Anonaspermum robertsi (Annonaceae); Protomimosoidea buchananensis, cf. Acrocarpus sp., cf.

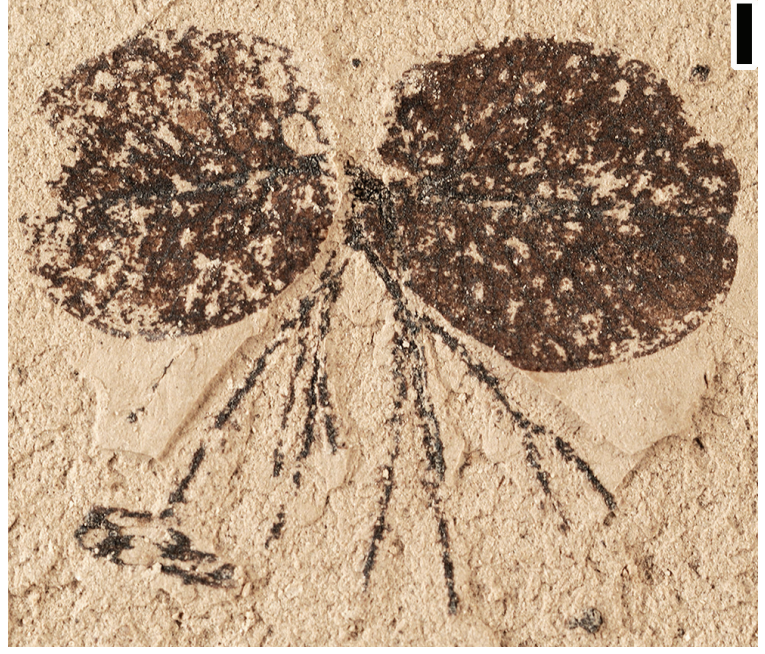

FIGURE 60. Salvinia preauriculata Berry, 1930; UF15737-030658. Specimen showing two floating fronds and a finely dissected, rootlike submerged frond. Scale bar equals $1 \mathrm{~mm}$.

Gleditsia? mississippiensis, "Short, broad winged fruit", Claiborne Fabaceae Floral Type 1 and 2 (Fabaceae); cf. Trigonobalanoidea americana, Claiborne Fagaceae Fruit Type 4 (Fagaceae); cf. Populus (Salicaceae); "Solanites" pusillus (Rhamnaceae); Gordonia warmanensis (Theaceae); Paleopanax boldensis (Araliaceae); Bridgesia bovayensis (Sapindaceae); Eucommia eocenica (Eucommiaceae); Dipelta bovayensis (Caprifoliaceae); and Natsiatum wilcoxiana (Icacinaceae). The rest (35 taxa/morphotypes) do not have enough diagnostic characters to assess their modern affinities.

\section{Comparison of Floristic Components of the Bovay and Bolden Localities}

Of the 52 reproductive taxa/morphotypes recognized from the Bovay and Bolden localities (Table 1), $38(73.1 \%)$ are unique to Bovay and nine $(17.3 \%)$ are unique to Bolden. Only five $(9.6 \%)$ taxa/morphotypes are shared by the two localities. This is a floristic pattern characteristic of Eocene clay deposits of Henry County, Tennessee, based on leaf and reproductive material (Potter and Dilcher, 1980). These floristic differences could result from several factors including variation in habitat (i.e., deposition in a swamp vs a lake/pond habitat), collecting conditions and age differences between the localities.

Johnston (1993) suggested that the depositional environment at the Bolden locality was a nearshore lentic environment based on the observation that delicate insects and flowers from the 
TABLE 5. Total numbers of specimens, leaves, and reproductive material from the Bovay and Bolden clay pit, Mississippi, and the Warman clay pit, Tennessee.

\begin{tabular}{lccccc}
\hline & & Bovay & Bolden & $\begin{array}{c}\text { Bovay and } \\
\text { Bolden }\end{array}$ & Warman \\
\hline \multicolumn{2}{l}{ Total number of specimens } & 505 & 187 & 692 & 3166 \\
Leaves & & 359 & 140 & 499 & 2560 \\
& Total number of reproductive material & 146 & 47 & 193 & 606 \\
$\begin{array}{l}\text { Reproductive } \\
\text { material }\end{array}$ & Identified & 89 & 18 & 107 & 338 \\
& Unidentified & 57 & 29 & 86 & 268 \\
\hline
\end{tabular}

Bolden locality are well preserved. At both the Bovay and Bolden localities, insects with appendages attached, leaves with organic material preserved, and angiosperm flowers with anthers attached indicate that burial occurred rapidly and with minimal transport before preservation (Johnston, 1993; Johnston and Borkent, 1998). The presence of the fresh water fern, Salvinia preauriculata Berry, 1925 from this locality (Figure 60) and other Claiborne localities (Berry, 1925, figure 4; Berry, 1930 , p. 47 , plate 7 , figures 2, 3; plate 50 , figure 1) also supports this interpretation. These results are consistent with Potter and Dilcher's (1980) suggestion that the middle Eocene clay lenses of western Kentucky and Tennessee represent clay plugs in ponds, lakes, or swamps which formed on a floodplain of the "Appalachian" River system.

The majority of the specimens examined were collected from the Tallahatta Formation of the Claiborne Group in northern Mississippi; however, the relative stratigraphic positions of the two localities are unknown. Therefore, the role time played in this floristic variation between the Bovay and Bolden localities is uncertain.

Other possible explanations for the floristic variation include differences in time spent collecting, in collecting conditions, and in abundance of fossils at each locality. There are a total of 505 specimens collected from the Bovay locality, including 359 leaves and 146 reproductive specimens (Table 5). In contrast, only 187 specimens, including 140 leaves and 47 reproductive materials, were collected from the Bolden locality.

\section{Comparison of Floristic Components with the Warman Locality, Tennessee}

Compared with the 62 taxa/morphotypes recognized from 606 specimens collected at the Warman clay pit, Tennessee (Table 1; Wang et al., 2013), only eight taxa/morphotypes are shared with Bovay and/or Bolden. These taxa/morphotypes are Anonaspermum robertsi (Annonaceae),
Protomimosoidea buchananensis (Fabaceae), cf. Gleditsia? mississippiensis (Fabaceae), Gordonia warmanensis (Theaceae), "Solanites" pusillus (Rhamnaceae), Claiborne Floral Type 5, Palmocarpon wilcoxiana, and "Sparganium" sp. The number of taxa/morphotypes from Warman has increased by one since our 2013 publication (Wang et al., 2013) due to the revision of fagaceous fruit types.

Earlier stratigraphic work divided the Eocene Claiborne Group from Mississippi into three formations (in ascending order), the Tallahatta, Lisbon, and the Yegua formations (for example, Cooke, 1925). The Tallahatta Formation was usually placed in the lower middle Eocene (Johnston, 1993; Johnston and Borkent, 1998) based on lithostratigraphic correlations. However, Dockery (1996, p. 4; Figure 3), in a paper revising the generalized stratigraphic column of Mississippi, placed the Tallahatta Formation in the upper lower Eocene (> 49 m.y.) based on correlation of the lithostratigraphy with calcareous nanofossil and planktonic foraminiferal zones and global chronostratigraphic units. Palynological data (Tschudy, 1973; Elsik, 1974; Elsik and Dilcher, 1974) from the Claiborne Group in Henry County, Tennessee, indicates that the fossil plant localities from western Tennessee and southeast Kentucky, including the Warman locality, are best considered to be from the upper middle Eocene (Cockfield Formation). This infers that the Tallahatta Formation is approximately 10 million years older than the Cockfield Formation (Figure 3), which is about 39 m.y. (Dockery, 1996). This time difference between the plant-bearing horizons from Mississippi and Tennessee localities may have played a key role in the floristic variations.

\section{CONCLUSIONS}

- Of the 52 taxa/morphotypes recognized from the Bovay and Bolden localities, Mississippi, 17 are identified to extant families. The rest (35 taxa/morphotypes) do not have enough 
diagnostic characters to assess their modern affinities.

- Of the 52 reproductive taxa/morphotypes recognized from the Bovay and Bolden localities, 38 are unique to Bovay and nine are unique to Bolden. Only five taxa/morphotypes are shared by the two localities. This is a floristic pattern characteristic of Eocene clay deposits of Henry County, Tennessee. The floristic differences could result from several factors including variation in habitat, collecting conditions, and age differences between the localities.

- Compared with the 62 taxa/morphotypes recognized from the Warman clay pit, Tennessee, only eight taxa/morphotypes are shared with Bovay or Bolden clay pit. The time difference (about 10 million years) between the plant-bearing horizons of the Mississippi and Tennessee localities may have played a key role in the floristic variation.

\section{ACKNOWLEDGMENTS}

We thank the following friends and colleagues, V. Call and family, P. Crane, P. Herendeen, W. Kovach, S. Manchester, T. Norman, C. Roose, and Z. Sun for collecting specimens from the Bovay and Bolden localities; Acme Brick, Holly Springs Plant, Mississippi, for access to the clay pits; S. Manchester for helpful discussions during the project and for sharing images of E.W. Berry's type specimens stored at the National Museum of Natural History; S. Manchester, N. Jud, and two anonymous reviewers for their critical and helpful comments and suggestions on the manuscript; and C. Snyder for photographing some specimens and for editing some images.

\section{REFERENCES}

Ablaev, A.G., Sin En, U., Vassiliev, I.V., and Lu, Z.M. 1993. Miocene of the North Korea and the South Primorye (Beds with Englhardia). Russian Academy of Sciences Far-eastern Branch, Pacific Institute of Oceanography, Dalnauka, Vladivostok. (In Russian)

Akhmetiev, M.A. 1991. Early Oligocene flora of Kiin-Kerish and its comparison with other Paleogene floras., p. 37-56. In Zhilin, S.G. (ed.), Development of the Flora in Kazakhastan and Russian Plain from the Eocene to the Miocene. Botanical Institute, Academy of Sciences of the USSR, Leningrad.

Allen, O.N. and Allen, E.K. 1981. The Leguminosae: A Source Book of Characteristics, Uses and Nodulation. University of Wisconsin Press, Madison, Wisconsin.
APG III (Angiosperm Phylogeny Group). 2009. An update of the Angiosperm Phylogeny Group classification for the orders and families of flowering plants: APG III. Botanical Journal of the Linnean Society, 161:105-121.

Arnott, G.A.W. 1834. Characters of three genera of Indian plants. The Edinburgh New Philosophical Journal, 16:314-316.

Arnott, G.A.W. 1838. Observations on some New or Obscure Species of Plants, No. II. Magazine of Zoology and Botany, 2:543-552.

Ball, O.M. 1931. A contribution to the paleobotany of the Eocene of Texas. Bulletin of the Agricultural and Mechanical College of Texas, 2:1-173.

Berry, E.W. 1914a. Fruits of a Date Palm in the Tertiary deposits of Eastern Texas. American Journal of Science, 4th series, 37:403-406.

Berry, E.W. 1914b. The Cretaceous and Eocene floras of South Carolina and Georgia. United States Geological Survey Professional Paper, 84:1-200.

Berry, E.W. 1915. A species of Copaifera from the Texas Eocene. Torreya, 15:41-44.

Berry, E.W. 1916a. Remarkable fossil fungi. Mycologia, 8:73-79.

Berry, E.W. 1916b. The Lower Eocene floras of southeastern North America. United States Geological Survey Professional Paper, 91:1-481.

Berry, E.W. 1922. Additions to the Flora of the Wilcox Group. United States Geological Survey Professional Paper, 131-A:1-21.

Berry, E.W. 1924. The Middle and Upper Eocene floras of southeastern North America. United States Geological Survey Professional Paper, 92:1-206.

Berry, E.W. 1925. A new Salvinia from the Eocene. Torreya, 25:116-118.

Berry, E.W. 1926. Terminalia in the Lower Eocene of Southeastern North America. Bulletin of the Torrey Botanical Club, 53:59-65.

Berry, E.W. 1928. A new type of caddis case from the Lower Eocene of Tennessee. U.S. Natural Museum Proceedings, 71:14.

Berry, E.W. 1930. Revision of the Lower and Upper Eocene Wilcox flora of the southeastern states. U.S. Geological Survey Professional Paper, 156:1-196.

Berry, E.W. 1941. Additions to the Wilcox flora from Kentucky and Texas. United States Geological Survey Professional Paper, 193-E:83-99.

Boissier, P.E. 1888. Enumeratio Plantarum in Oriente a Græcia et ÆEgypto ad Indlæ Fine Hucusque Observatarum. In Buser R. (ed.), Flora Oriental Supplementum. H. Georg, Genevae et Basilae.

Boucher, L.D., Manchester, S.R., and Judd, W.S. 2003. An extinct genus of Salicaceae based on twigs with attached flowers, fruits, and foliage from the Eocene Green River Formation of Utah and Colorado, USA. American Journal of Botany, 90:1389-1399.

Bromhead, E.F. 1838. An attempt to ascertain characters of the botanical alliances. Edinburgh New Philosophical Journal, 25:123-34. 
Brown, R.W. 1940. New species and changes of name in some American fossil floras. Journal of the Washington Academy of Sciences, 30:344-356.

Burnham, R.J. 1995. A new species of winged fruit from the Miocene of Ecuador: Tipuana ecuatoriana (Leguminosae). American Journal of Botany, 82:15991607.

Burnham, R.J. and Carranco, N.L. 2004. Miocene winged fruits of Loxopterygium (Anacardiaceae) from the Ecuadorian Andes. American Journal of Botany, 91:1767-1773.

Call, V.B. and Dilcher, D.L. 1997. The fossil record of Eucommia (Eucommiaceae) in North America. American Journal of Botany, 84:798-814.

Call, V.B. and Dilcher, D.L. 1992. Investigations of angiosperms from the Eocene of southeastern North America: samaras of Fraxinus wilcoxiana Berry. Review of Palaeobotany and Palynology, 74:249266.

Call, V.B., Manchester, S.R., and Dilcher, D.L. 1993. Wetherellia fruits and associated fossil plant remains from the Paleocene/Eocene Tuscahoma-Hachetigbee Interval, Meridian, Mississippi. Mississippi Geology, 14:10-18.

Cambessèdes, J. 1834. Note sur deux genres nouveaux de la famille des Sapindacées. Nouvelles Annales du Muséum d'Histoire Naturelle, 3:231-238.

Chen, Y. and Manchester, S.R. 2015. Winged Fruits of Deviacer in the Oligocene from the Ningming Basin in Guangxi, South China. PLoS ONE, 10(12):e0144009. doi:10.1371/journal.pone.0144009.

Collinson, M.E., Manchester, S.R., and Wilde, V. 2012. Fossil Fruits and Seeds of the Middle Eocene Messel biota, Germany. Abh. Senckenberg Ges. Naturforsch., 570:1-249.

Collinson, M.E., Manchester, S.R., Wilde, V., and Hayes, P. 2010. Fruit and seed floras from exceptionally preserved biotas in the European Paleogene. Bulletin of Geosciences, 85:95-102.

Cooke, W. 1925. Correlation of the Eocene formations in Mississippi and Alabama. United States Geological Survey Professional Paper, 140E:133-136.

Crepet, W.L. 1978. Investigations of Angiosperms from the Eocene of North America: an aroid inflorescence. Review of Palaeobotany and Palynology, 25:241252.

Crepet, W.L. 1979. Some aspects of the pollination biology of middle Eocene angiosperms. Review of Palaeobotany and Palynology, 27:213-238.

Crepet, W.L. 1984. Advanced (constant) insect pollination mechanisms: pattern of evolution and implications vis-a-vis angiosperm diversity. Annals of the Missouri Botanical Garden 71:607-630.

Crepet, W.L. and Daghlian, C.P. 1982. Euphorbioid inflorescences from the middle Eocene Claiborne Formation. American Journal of Botany, 69:258-266.

Crepet, W.L. and Dilcher, D.L. 1977. Investigations of angiosperms from the Eocene of North America: a mimosoid inflorescence. American Journal of Botany, 64:714-725.

Crepet, W.L., Dilcher, D.L., and Potter, F.W. 1975. Investigations of angiosperms from the Eocene of southeastern North America: a catkin with Juglandaceous affinities. American Journal of Botany, 62:813-823.

Crepet, W.L. and Feldman, G.D. 1991. Earliest fossil evidence of grasses in the fossil record. American Journal of Botany, 78:1010-1014.

Crepet, W.L. and Nixon, K.C. 1989. Earliest megafossil evidence of Fagaceae: phylogenetic and biogeographic implications. American Journal of Botany, 76:842-855.

Crepet, W.L. and Taylor, D.W. 1985. The diversification of the Leguminosae: first fossil evidence of the Mimosoideae and Papilionoideae. Science, 288:10871089.

Crepet, W.L. and Taylor, D.W. 1986. Primitive mimosoid flowers from the Paleocene-Eocene and their systematic and evolutionary implications. American Journal of Botany, 73:548-563.

Daghlian, C.P. and Crepet, W.L. 1983. Oak catkins, leaves and fruits from the Oligocene Catahoula Formation and their evolutionary significance. American Journal of Botany, 70:639-649.

de Jussieu, A.L. 1789. Genera Plantarum, secundum ordines naturales disposita juxta methodum in Horto Regio Parisiensi exaratam. Herissant \& Barrois, Paris.

de Mirbel, C.F.B. 1815. Eléments de Physiologie Végétale et de Botanique, 2 tomes et 1 de planches. Magimel, Paris.

DeVore, M.L., Pigg, K.B., Dilcher, D.L., and Freile, D. 2014. Catahoulea grahamii, a new genus and species of fagaceous involucres from the Oligocene Catahoula Formation, central Texas, and the middle Eocene Claiborne Formation of Kentucky and Tennessee, U.S.A., p.39-50. In Stevens, W.D., Montiel, O.M., Raven, P.H. (eds.), Paleobotany and Biogrography, A Festschrift for Alan Graham in His 80th Year. Missouri Botanical Garden Press, St. Louis, Missouri.

Dilcher, D.L. and Dolph, G.E. 1970. Fossil leaves of Dendropanax from Eocene sediments of Southeastern North America. American Journal of Botany, 57:153160.

Dilcher, D.L., Potter, F.W., and Crepet, W.L. 1976. Investigations of angiosperms from the Eocene of North America: Juglandaceous winged fruits. American Journal of Botany, 63:532-544.

Dockery, D.T. 1996. Toward a revision of the generalized stratigraphic column of Mississippi. Mississippi Geology, 17:1-9.

Dumortier, B.C.J. 1829. Analyse des familles des plantes, avec l'indication des principaux genres qui s'y rattachent. Casterman, Tournay.

Ellis, J. 1771. A copy of a letter from John Ellis to Dr. Linnaeus. Philosophical Transactions of the Royal Society of London, 60:518-523. 
Elsik, W.C. 1974. Characteristic Eocene palynomorphs in the Gulf Coast, U.S.A. Palaeontographica, Abst. B, 149:90-111.

Elsik, W.C. and Dilcher, D.L. 1974. Palynology and age of clays exposed in Lawrence clay pit, Henry County, Tennessee. Palaeontographica, Abst. B, 146:65-87.

Engler, H.G.A. 1892. Syllabus der Vorlesungen über Specielle und Medicinisch-pharceutische Botanik. Gebrüder Borntraeger Verlag, Berlin.

Engler, H.G.A. 1907. Syllabus der Pflanzenfamilien. Gebrüder Borntraeger Verlag, Berlin.

Friis, E.M. and Crepet, W.L. 1987. Time of appearance of floral features, p. 145-179. In Friis, E.M., Chaloner, W.G., and Crane, P.R. (eds.), Angiosperm Origins and Biological Consequences. Cambridge University Press, Cambridge.

Geng, B.Y., Manchester, S.R., and Lu, A.M. 1999. The first discovery of Eucommia fruit fossil in China. Chinese Science Bulletin, 44:1506-1508.

Graham, A. 2009. Fossil record of the Rubiaceae. Annals of the Missouri Botanical Garden, 96:90-108.

Grote, P.J. and Dilcher, D.L. 1992. Fruits and Seeds of Tribe Gordonieae (Theaceae) from the Eocene of North America. American Journal of Botany, 79:744753.

Herendeen, P.S. 1992. The fossil history of the Leguminosae from the Eocene of southeastern North America, p. 85-160. In Herendeen, P.S. and Dilcher, D.L. (eds.), Advances in Legume Systematics: Part 4. The Fossil Record. The Royal Botanic Gardens, UK, Kew.

Herendeen, P.S., Crepet, W.L., and Dilcher, D.L. 1992. The fossil history of the Leguminosae: Phylogenetic and biogeographic implications, p. 303-316. In Herendeen, P.S., and Dilcher, D.L. (eds.), Advances in Legume Systematics, Part 4, The Fossil Record. Royal Botanic Gardens, Kew, UK.

Hu, H.H. and Chaney, R.W. 1940. A Miocene flora from Shantung Province, China. Publication of the Carnegie Institution of Washington, 507:1-147.

Huzioka, K. 1961. A new Paleogene species of the genus Eucommia from Hokkaido, Japan. Transactions and Proceedings of the Palaeontological Society of Japan, 41:9-12.

IPNI (The International Plant Names Index). 2016. http:// www.ipni.org. Accessed 1 May 2016.

Johnston, J.E. 1993. Insects, spiders, and plants from the Tallahatta Formation (middle Eocene) in Benton County, Mississippi. Mississippi Geology, 14:71-82.

Johnston, J.E. and Borkent, A. 1998. Chaoborus lichtenstein (Diptera: Chaoboridae) pupae from the middle Eocene of Mississippi. Journal of Paleontology, 72:491-493.

Ker Gawler, J.B. 1816. Camellia japonica. The Botanical Register: Consisting of Coloured Figures of Exotic Plants, Cultivated in British Gardens; with Their History and Mode of Treatment, 2:212.

Kirkbride, J.H.J., Gunn, C.R., and Dallwitz, M.J. 2006. Family Guide for Fruits and Seeds, vers. 1.0. URL: /
SBMLWeb/OnlineResources/frsdfam/Index.cfm Accessed May 5, 2015.

Kirkbride, J.H.J., Gunn, C.R., Weitzman, A.L., and Dallwitz, M.J. 2015. Legume (Fabaceae) Fruits and Seeds, Version 2. http://nt.ars-grin.gov/seedsfruits/ keys/fabaceae/index.cfm.Accessed May 5, 2015.

Kvaček, Z. and Sakala, J. 1999. Twig with attached leaves, fruits and seeds of Decodon (Lythraceae) from the Lower Miocene of northern Bohemia, and implications for the identification of detached leaves and seeds. Review of Palaeobotany and Palynology, 107:201-222.

Kvaček, Z. and Wilde, V. 2010. Foliage and seeds of malvalean plants from the Eocene of Europe. Bulletin of Geosciences (Czech Geological Survey, Prague), 85:163-182.

Lesquereux, L. 1869. On Species of Fossil Plants from the Tertiary of the State of Mississippi. Transactions of the American Philosophical Society, New Series, 13:411-433.

Li, X.W., Li, J., Huang, P.H., Wei, F.N., Cui, H.B., and van der Werff, H. 2008. Lauraceae. Flora of China, 7:102254.

Lindley, J. 1846. The Vegetable Kingdom; or, the Structure, Classification and Uses of Plants, Illustrated upon the Natural System. Bradbury \& Evans, London.

Linnaeus, C. 1742. Genera Plantarum Eorumque Characteres Naturales Secundum Numerum, Figuram, Situm, \& Proportionem Omnium Fructificationis Partium. Edition 2. Conrandum Wishoff, et Georg. J. Witoff, Fil. Conr., Lugdunum Batavorum.

Linnaeus, C. 1753. Species Plantarum. Impensis Laurentii Salvii, Holmiæ (Stockholm).

Linnaeus, C. 1768. Systema naturæ per regna tria naturæ, secundum classes, ordines, genera, species, cum characteribus, differentiis, synonymis, locis. Impensis Laurentii Salvii, Holmiæ (Stockholm).

Magallón-Puebla, S. and Cevallos-Ferriz, S.R.S. 1994. Eucommia constans n. sp. fruits from upper Cenozoic strata of Puebla, Mexico: Morphological and anatomical comparison with Eucommia ulmoides Oliver. International Journal of Plant Sciences, 155:8085.

Mai, D.H. 1995. Tertiäre Vegetationsgeschichte Europas. Gustav Fischer, Jena/Stuttgart/New York.

Manchester, S.R. 1994. Fruits and Seeds of the Middle Eocene Nut Beds Flora, Clarno Formation, Oregon. Palaeontographica Americana, 58:1-205.

Manchester, S.R. 1999. Biogeographical relationships of North American Tertiary Floras. Annals of the Missouri Botanical Garden, 86:472-522.

Manchester, S.R. 2000. Late Eocene fossil plants of the John Day Formation, Wheeler County, Oregon. Oregon Geology, 62:51-63.

Manchester, S.R. 2001. Update on the megafossil flora of Florissant, Colorado. Denver Museum of Nature \& Science, Series 4:137-161. 
Manchester, S.R., Calvillo-Canadell, L., and CevallosFerriz, S.R.S. 2014. Assembling extinct plants from their isolated parts. Boletín de la Sociedad Geológica Mexicana, 66:53-63.

Manchester, S.R., Chen, Z., Lu, A., and Uemura, K. 2009. Eastern Asian endemic seed plant genera and their paleogeographic history throughout the Northern Hemisphere. Journal of Systematics and Evolution, 47:1-42.

Manchester, S.R., Judd, W.S., and Handley, B. 2006. Foliage and fruits of early poplars (Salicaceae: Populus) from the Eocene of Utah, Colorado, and Wyoming. International Journal of Plant Science, 167:897-908.

Manchester, S.R. and O'Leary, E.L. 2010. Phylogenetic Distribution and Identification of Fin-winged Fruits. The Botanical Review, 76:1-82.

Martínez-Millán, M. 2010. Early Fossil Record of the Asteridae; Revision, Identification, Phylogenetics and Timing, Cornell University, Ithaca, New York.

Maximowicz, C.J. 1877. Diagnoses plantarum novarum asiaticarum II. Bulletin de I'Academie Imperiale des Sciences de Saint-Pétersbourg, 24:55-79.

McNeill, J., Barrie, F.R., Buck, W.R., Demoulin, V., Greuter, W., Hawksworth, D.L., Herendeen, P.S., Knapp, S., Marhold, K., Prado, J., Prud'homme van Reine, W.F., Smith, G.F., H., W.J., and Turland, N.J. 2012 (eds.), International Code of Nomenclature for Algae, Fungi, and Plants (Melbourne Code). Regnum Vegetabile 146. A.R.G. Gantner Verag, Ruggell.

Meyer, H.W. and Manchester, S.R. 1997. The Oligocene Bridge Creek flora of the John Day Formation, Oregon. University of California Publications Geological Sciences, 141:1-195.

Miers, J. 1851. Observations on the affinities of the Olacaceae. The Annals and Magazine of Natural History, ser. 2, 8: 161-184.

Millan, M. and Crepet, W.L. 2014. The fossil record of the Solanaceae revisited and revised- the fossil record of Rhamnaceae enhanced. Botanical Review, 80:73106.

Nakai, T. 1930. Hisi-Shokubutsu. Iwanami Shoten, Publishers, Tokyo.

Negru, A.G. 1972. Early Sarmatian flora of northeastern Moldavia, Academy of Sciences of Moldavskoi SSR Botanical Garden. Shtiinsta Publishing House, Kishinev. (In Russian)

Nixon, K.C. 1997. Fagaceae. Flora of North America North of Mexico. 18+ vols., New York and Oxford.

Oliver, D. 1890. Eucommia ulmoides. In Hooker, W.J. (ed.), Icones Plantarum. Longman, London.

Pigg, K.B., DeVore, M.L., and Wojciechowski, M.F. 2008. Paleosecuridaca curtisii gen. et sp. nov., Securidacalike samaras (Polygalaceae) from the late Paleocene of North Dakota and their significance to the divergence of families within the Fabales. International Journal of Plant Science, 169:1304-1313.

Polhill, R.M. and Vidal, J.E. 1981. Caesalpinieae, p. 8196. In Polhill, R.M. and Raven, P.H. (eds.), Advances in Legume Systematics, Part 1. Royal Botanic Gardens, Kew.

Potter, F.W. and Dilcher, D.L. 1980. Biostratigraphic analysis of Middle Eocene floras of western Kentucky and Tennessee, p. 211-225. In Dilcher, D.L. and Taylor, T.N. (eds.), Biostratigraphy of Fossil Plants: Successional and Paleoecological Analysis. Dowden, Hutchinson and Ross Publishers, Stroudsburg, Pennsylvania.

Rafinesque, C.S. 1827. The Casket, or, Flowers of Literature, Wit \& Sentiment. Atkinson \& Alexander, Philadelphia

Reid, E.M. and Chandler, M.E.J. 1926. Catalogue of Cainozoic Plants in the Department of Geology. Vol. 1. The Bembridge Flora. British Museum of Natural History, London.

Roth, J.L. and Dilcher, D.L. 1979. vestigations of angiosperms from the Eocene of North America: stipulate leaves of the Rubiaceae including a probable polyploid population. American Journal of Botany, 66:1194-1207.

Saporta, G. 1862. Études sur la végétation du sud-est de la France a l'époque tertiaire. Annales des Sciences Naturelles; Botanique, Série 4, 17:191-303.

Shi, X.G., Jin, J.H., Ye, C.X., and Liu, W.Q. 2012. First fruit fossil record of Morinda (Rubiaceae) from China. Review of Palaeobotany and Palynology, 179:13-16.

Stevens, P.F. 2001 onwards. Angiosperm Phylogeny Website. Version 12, July 2012. http:// www.mobot.org/MOBOT/research/APweb.

Stull, G.W., Moore, B.R., and Manchester, S.R. 2011. Fruits of Icacinaceae from the Eocene of Southeastern North America and Their Biogeographic Implications. International Journal of Plant Sciences, 172:935-947.

Szafer, W. 1950. The family Eucommiaceae in the Tertiary of Europe. Kosmos, A:378-409. (In Polish with English summary)

Szafer, W. 1954. Pliocene flora from the vicinity of Czorsztyn (West Carpathians) and its relationship to the Pleistocene. Instytut Geologiczny Prace, 11:1238.

Tanai, T. 1961. Neogene floral changes in Japan. Journal of the faculty of Science, Hokkaido Imperial University, ser. IV, Geology and Mineralolgy, 11:120-400.

Tralau, H. 1963. Asiatic dicotyledonous affinities in the Cainozoic flora of Europe. Kongliga Svenska Vetenskaps-Akademiens Handlingar, 9(3):1-87.

Tschudy, R.H. 1973. Stratigraphic distribution of significant Eocene palynomorphs of the Mississippi Embayment. U. S. Geological Survey Professional Paper, 743B:1-24.

van Tieghem, P.E.L. 1900. Sur le genre Lophire considéré comme type d'une famille distincte, les Lophiracées. Journal de Botanique, 15:169-194.

von Berchtold, F. and Presl, J.S. 1820. O přirozenosti rostlin aneb rostlinář: obsahugjcj gedanj on ziwobytj rostlinném pro sebe az ohledu giných žiwokủ podlé stawu nyněgssjbo znanj $k$ rozssjřenj prirodnictwj, w 
potaženj na užitećnost w rolnictwj hospodářstwj remestech umenj $i$ obchodu a w wztahowanj obzwlásstnjm obzwlásstnjm na lekarstwj. K.W. Kubersa, Praze.

von Martius, C.F.P. 1835. Conspectus Regni Vegetabilis Secundum Characteres Morphologicas praesertim carpicos et in classes ordines et familias digesti. Johann Leonhard Schrag, Nürnberg.

Wang, H., Blanchard, J., and Dilcher, D.L. 2013. Fruits, seeds, and flowers from the Warman clay pit (middle Eocene Claiborne Group), western Tennessee, USA. Palaeontologia Electronica, 16(3):1-73.

Wang, Y.F., Li, C.S., Collinson, M., E., Lin, J., and Sun, Q.G. 2003. Eucommia (Eucommiaceae), a potential biothermometer for the reconstruction of Paleoenvironments. American Journal of Botany, 90:1-7.

Wang, Y.F., Li, C.S., Li, Z., and Fu, D. 2001. Wuyunanthus gen. nov., a flower of Celastraceae from the
Palaeocene of north-east China. Botanical Journal of the Linnean Society, 136:323-327.

Watson, L. and Dallwitz, M.J. 1992 onwards. The families of flowering plants: descriptions, illustrations, identification, and information retrieval. Version: 22nd April 2014. http://delta-intkey.com.

Wheeler, E.A. and Manchester, S.R. 2014. Middle Eocene trees of the Clarno Petrified Forest, John Day Fossil Beds National Monument, Oregon. PaleoBios, 30:5-114.

Yang, Q.E. and Landrein, S. 2011. Linnaeaceae. Flora of China, 19:642-648.

Zhang, Z.Y., Zhang, H.D., and Turland, N.J. 2003. Eucommiaceae. Flora of China, 9:43.

Zhilin, S.G. 1989. History and development of the temperate forest flora in Kazakhstan: USSR from the Oligocene to the Early Miocene. Botanical Review, 55:205-330. 